Prepared in cooperation with the Pennsylvania Department of Environmental Protection, Bureau of Mining and Reclamation

\title{
Factors Affecting Specific-Capacity Tests and their Application-A Study of Six Low-Yielding Wells in Fractured-Bedrock Aquifers in Pennsylvania
}

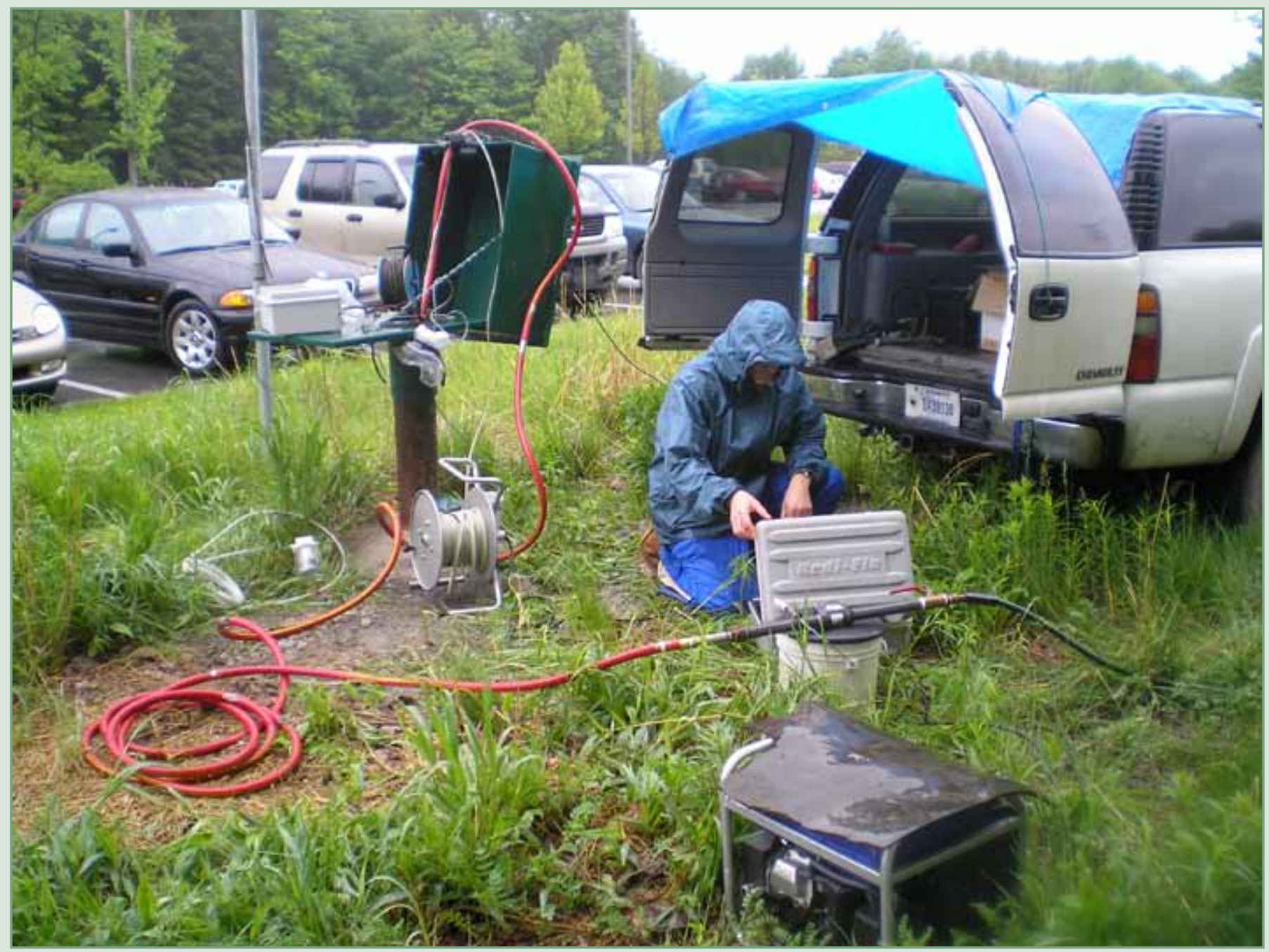

Scientific Investigations Series 2010-5212 
Cover.

Specific-capacity testing at Cambria County well CA 462. Photograph by Randall Conger, U.S. Geological Survey. 


\section{Factors Affecting Specific-Capacity Tests and their Application-A Study of Six Low-Yielding Wells in Fractured-Bedrock Aquifers in Pennsylvania}

By Dennis W. Risser

In cooperation with the Pennsylvania Department of Environmental Protection, Bureau of Mining and Reclamation

Scientific Investigations Report 2010-5212 


\section{U.S. Department of the Interior \\ KEN SALAZAR, Secretary \\ U.S. Geological Survey \\ Marcia K. McNutt, Director}

U.S. Geological Survey, Reston, Virginia: 2010

For more information on the USGS - the Federal source for science about the Earth, its natural and living resources, natural hazards, and the environment, visit http://www.usgs.gov or call 1-888-ASK-USGS

For an overview of USGS information products, including maps, imagery, and publications, visit http://www.usgs.gov/pubprod

To order this and other USGS information products, visit http://store.usgs.gov

Any use of trade, product, or firm names is for descriptive purposes only and does not imply endorsement by the U.S. Government.

Although this report is in the public domain, permission must be secured from the individual copyright owners to reproduce any copyrighted materials contained within this report.

Suggested citation:

Risser, D.W., 2010, Factors affecting specific-capacity tests and their application-A study of six low-yielding wells in fractured-bedrock aquifers in Pennsylvania: U.S. Geological Survey Scientific Investigations Report 2010-5212, 44 p. 


\section{Contents}

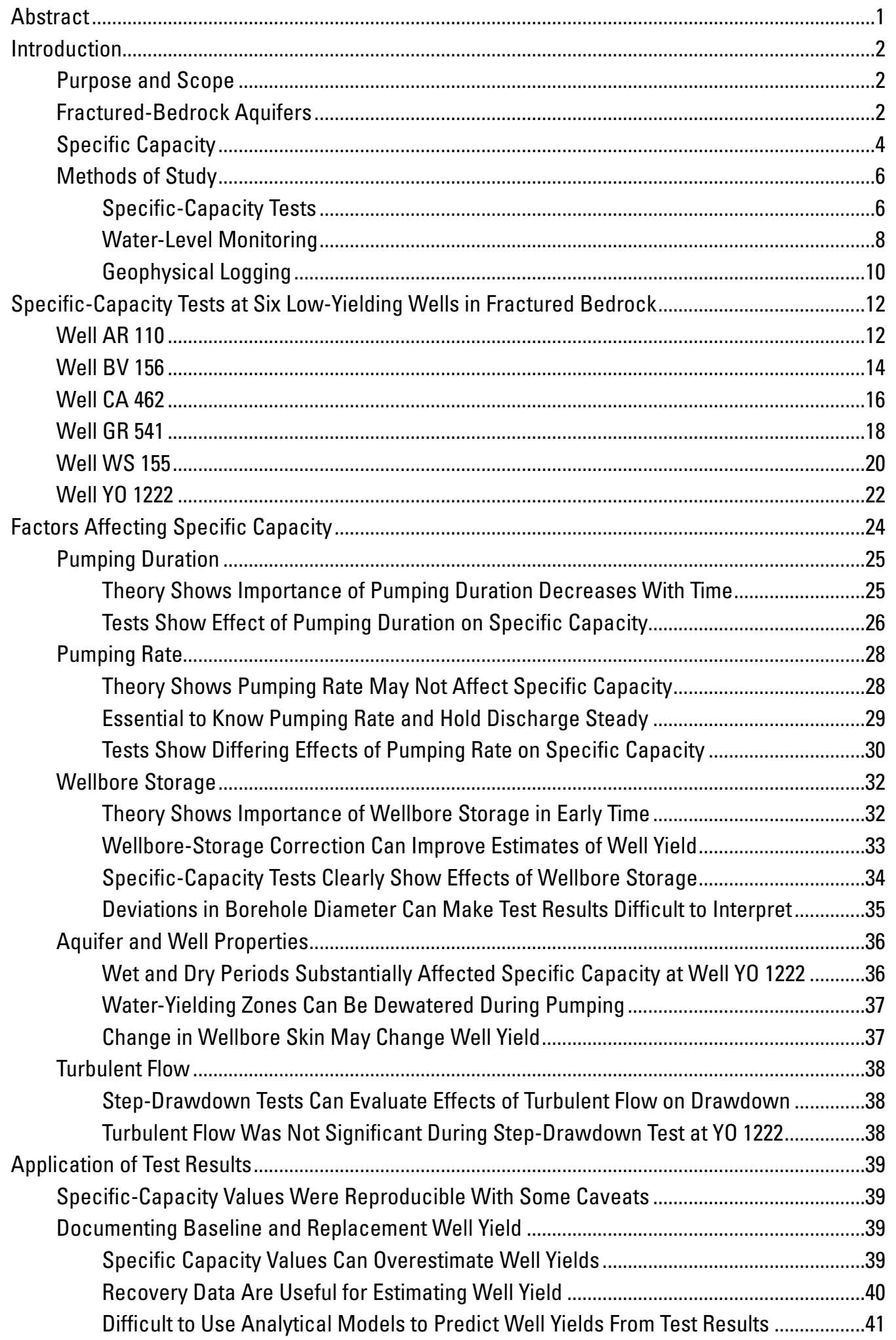


Y0 1222.

WS 155.

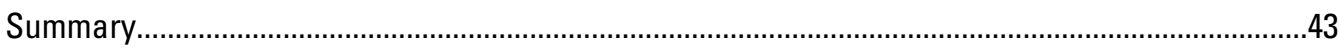

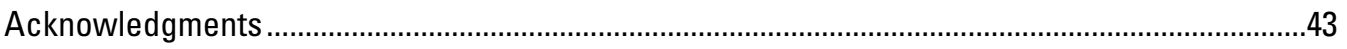

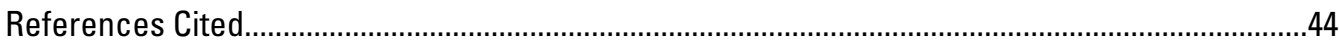

\section{Figures}

1. Map showing location of six low-yielding wells in fractured-bedrock aquifers in areas of coal or carbonate-rock mining in Pennsylvania selected for testing for this study

2. Schematic of components of drawdown caused by laminar $(B Q)$ and turbulent $\left(C Q^{2}\right)$ flow of water to a pumped well in an ideal confined aquifer......

3. Graphs showing water-level fluctuations and dates of pumping for six low-yielding wells in fractured-bedrock aquifers in Pennsylvania

4. Graph showing variation in wellbore diameter (caliper log), range of natural water-level fluctuations 2007-09, and locations of major water-yielding zones as determined from geophysical logging and driller reports for six low-yielding wells in fractured-bedrock aquifers in Pennsylvania.

5. Images from the borehole video log showing fractures intersected by wells BV 156 and YO 1222

6 Graphs showing water level $(A)$ and specific capacity $(B)$ during five specific-capacity tests at well AR 110 in Armstrong County, Pennsylvania

7. Graphs showing water level $(A)$ and specific capacity $(B)$ during five specific-capacity tests at well BV 156 in Beaver County, Pennsylvania

8. Graphs showing water level $(A)$ and specific capacity $(B)$ during five specific-capacity tests at well CA 462 in Cambria County, Pennsylvania

9. Graphs showing water level $(A)$ and specific capacity $(B)$ during five specific-capacity tests at well GR 541 in Greene County, Pennsylvania

10. Graphs showing water level $(A)$ and specific capacity $(B)$ during five specific-capacity tests at well WS 155 in Washington County, Pennsylvania

11. Graphs showing water level $(A)$ and specific capacity $(B)$ during five specific-capacity tests at well YO 1222 in York County, Pennsylvania

12. Schematic diagram of a hypothetical well in an idealized homogeneous aquifer used in the theoretical analysis of some factors affecting specific capacity......

13. Graphs showing change in drawdown and specific capacity with duration of pumping for constant withdrawal of 2 gallons per minute from a hypothetical 6 -inch diameter well in an idealized aquifer with transmissivity 10 feet squared per day and storage coefficient of 0.0001 .

14. Graphs showing drawdown $(A)$ and specific capacity $(B)$ with time during selected specific-capacity tests at six low-yielding wells in fractured-bedrock aquifers in Pennsylvania

15. Graph showing theoretical specific capacity with and without turbulent flow for pumping at rates from 2 to 10 gallons per minute for 180 minutes in a hypothetical 6 -inch diameter well with wellbore storage .

16. Graph showing variability of the pumping rate during the 2.5 gallon-per-minute specific-capacity test at well WS 155 in July 2008. 
17. Graph showing theoretical drawdown for constant-rate pumping at 5 gallons per minute and varied-rate pumping at 6 gallons per minute for 90 minutes followed by 4 gallons per minute for 90 minutes at the hypothetical well.

18. Graph showing specific-capacity values for tests completed at different rates after 60 minutes of pumping at six low-yielding wells in fractured-bedrock aquifers in Pennsylvania ...

19. Graphs showing drawdown $(A)$ and specific capacity $(B)$ for well diameters of 4,6 , and 8 inches simulated with the hypothetical well

20. Graphs showing specific capacity adjusted by removing water from wellbore storage compared to unadjusted specific capacity for $(A)$ the 6 -inch diameter hypothetical well and $(B)$ well CA 462 in Cambria County, Pennsylvania

21. Graph showing incremental percentage of pumped volume provided by wellbore storage for three specific-capacity tests at rates of 1,2, and 4.5 gallons per minute at well CA 462 in Cambria County, Pennsylvania

22. Graph showing caliper log and drawdown and recovery of water-level resulting from pumping at 1.5 gallons per minute on July 23 and November 25, 2008, showing effects of deviations in wellbore diameter in well GR 541 in Greene County, Pennsylvania ...

23. Graph showing water-level fluctuations in well YO 1222 in York County, Pennsylvania, during June to August 2009 showing change in recession slope at depth of a water-yielding zone 27 feet below land surface...

24. Image from borehole video log showing a particulate flocculent floating in the water in well AR 110

25. Graph showing determination of turbulent-flow factors $B$ and $C$ in equation 4 from the step-drawdown test at well YO 1222 in York County, Pennsylvania, in August 2008 by the method of Bierschenk

26. Graph showing drawdown and recovery of water level during the March 2008 specific-capacity test at well WS 155 in Washington County, Pennsylvania

27. Graphs showing measured drawdown from three tests at well YO 1222 in York County, Pennsylvania, and drawdown predicted with the analytical solution of Papadopulos and Cooper with transmissivity of 33 feet squared per day, storage coefficient of $1.75 \times 10^{-7}$, and well diameter of 6.25 inches

28. Graph showing measured water-level drawdown and recovery from the May 2009 specific-capacity test at well WS 155 in Washington County, Pennsylvania, compared to simulated water levels from the analytical solution of Barker for one-dimensional flow to the well. 


\section{Tables}

1. Characteristics of six low-yielding wells in fractured-rock aquifers in Pennsylvania

2. Summary of results from multiple specific-capacity tests completed at six low-yielding wells in fractured-bedrock aquifers in Pennsylvania.

3. Comparison of specific-capacity values after 60 and 180 minutes of pumping...............26

4. Specific-capacity values from two or three tests completed at the same pumping rate at each of six low-yielding wells in fractured-bedrock aquifers in Pennsylvania

5. Specific-capacity values from tests completed at different pumping rates at six low-yielding wells in fractured-bedrock aquifers in Pennsylvania

\section{Conversion Factors and Abbreviations}

Inch/Pound to SI

\begin{tabular}{|c|c|c|}
\hline Multiply & By & To obtain \\
\hline \multicolumn{3}{|c|}{ Length } \\
\hline inch (in.) & 2.54 & centimeter $(\mathrm{cm})$ \\
\hline inch (in.) & 25.4 & millimeter $(\mathrm{mm})$ \\
\hline foot $(\mathrm{ft})$ & 0.3048 & meter $(\mathrm{m})$ \\
\hline mile (mi) & 1.609 & kilometer $(\mathrm{km})$ \\
\hline \multicolumn{3}{|c|}{ Area } \\
\hline square foot $\left(\mathrm{ft}^{2}\right)$ & 929.0 & square centimeter $\left(\mathrm{cm}^{2}\right)$ \\
\hline square foot $\left(\mathrm{ft}^{2}\right)$ & 0.09290 & square meter $\left(\mathrm{m}^{2}\right)$ \\
\hline \multicolumn{3}{|c|}{ Volume } \\
\hline gallon (gal) & 3.785 & liter (L) \\
\hline \multicolumn{3}{|c|}{ Flow rate } \\
\hline gallon per minute (gal/min) & 0.06309 & liter per second $(\mathrm{L} / \mathrm{s})$ \\
\hline \multicolumn{3}{|c|}{ Specific capacity } \\
\hline $\begin{array}{l}\text { gallon per minute per foot } \\
[(\mathrm{gal} / \mathrm{min}) / \mathrm{ft})]\end{array}$ & 0.2070 & liter per second per meter $[(\mathrm{L} / \mathrm{s}) / \mathrm{m}]$ \\
\hline \multicolumn{3}{|c|}{ Transmissivity* } \\
\hline foot squared per day $\left(\mathrm{ft}^{2} / \mathrm{d}\right)$ & 0.09290 & meter squared per day $\left(\mathrm{m}^{2} / \mathrm{d}\right)$ \\
\hline
\end{tabular}

Horizontal coordinate information is referenced to the North American Datum of 1983 (NAD 83).

*Transmissivity: The standard unit for transmissivity is cubic foot per day per square foot times foot of aquifer thickness [(ft $\left.\left.\mathrm{ft}^{3} \mathrm{~d}\right) / \mathrm{ft}^{2}\right] \mathrm{ft}$. In this report, the mathematically reduced form, foot squared per day $\left(\mathrm{ft}^{2} / \mathrm{d}\right)$, is used for convenience. 


\title{
Factors Affecting Specific-Capacity Tests and their Application-A Study of Six Low-Yielding Wells in Fractured-Bedrock Aquifers in Pennsylvania
}

\author{
By Dennis W. Risser
}

\section{Abstract}

This report by the U.S. Geological Survey, prepared in cooperation with the Pennsylvania Department of Environmental Protection, Bureau of Mining and Reclamation, evaluates factors affecting the application of specific-capacity tests in six low-yielding water wells in areas of coal mining or quarrying in Pennsylvania. Factors such as pumping rate, duration of pumping, aquifer properties, wellbore storage, and turbulent flow were assessed by theoretical analysis and by completing multiple well tests, selected to be representative of low-yielding household-supply wells in areas of active coal mining or quarrying. All six wells were completed in fractured-bedrock aquifers-five in coal-bearing shale, siltstone, sandstone, limestone, and coal of Pennsylvanian and Permian age and one in limestone of Cambrian age. The wells were pumped 24 times during 2007-09 at rates from 0.57 to 14 gallons per minute during tests lasting from 22 to 240 minutes. Geophysical logging and video surveys also were completed to determine the depth, casing length, and location of water-yielding zones in each of the test wells, and seasonal water-level changes were measured during 2007-09 by continuous monitoring at each well.

The tests indicated that specific-capacity values were reproducible within about \pm 20 percent if the tests were completed at the same pumping rate and duration. A change in pumping duration, pumping rate, or saturated aquifer thickness can have a substantial effect on the comparability of repeated tests. The largest effect was caused by a change in aquifer thickness in well YO 1222 causing specific capacity from repeated tests to vary by a factor of about 50 . An increase in the duration of pumping from 60 to 180 minutes caused as much as a 62 percent decrease in specific capacity. The effect of differing pumping rates on specific capacity depends on whether or not the larger rate causes the water level in the well to fall below a major water-yielding zone; when this decline happened at well CA 462, specific capacity was reduced by about 63 percent.

Estimates of the maximum yield for low-yielding wells that are computed by multiplying the available drawdown by the specific-capacity value may contain large errors if the wells were pumped at low rates that do not cause much water-level drawdown. The estimates of yield are likely to be too large because the effects of lowering the water level in the well below water-yielding zones have not been incorporated. Better yield estimates can be made by the use of stepdrawdown tests or by over-pumping at a rate large enough to dewater most of the wellbore. The maximum well yield, after overpumping, can be estimated from the rate of water-level recovery or by subtracting the incremental rate of change of borehole storage at the end of the test from the pumping rate. 


\section{Introduction}

Pennsylvania Department of Environmental Protection (PaDEP) regulations require a mining company to restore or replace the water supply if a mining company diminishes the yield of a well to the point where the well is no longer adequate for the purposes served (Commonwealth of Pennsylvania, 1982, 1990, 1998, 2005). PaDEP typically has used specific-capacity tests to establish baseline well yields, to determine mining effects on domestic supply wells, and to verify that replacement wells (if needed) have adequate yields. Specific capacity is the ratio of pumping rate to drawdown determined at some specified time during the test. Although the specific-capacity test has proven useful, the procedure for determining mining effects is based on the assumption that test results are reproducible and that differences between successive tests are caused by mining activity. Factors other than mining can affect the results of specific-capacity tests, but the importance of those effects is not well understood, particularly with low-yielding wells.

PaDEP often needs to evaluate the results of specificcapacity tests at domestic-supply wells for differing durations, pumping rates, and hydrologic conditions. Domestic-supply wells in Pennsylvania are frequently low-yielding (often less than $5 \mathrm{gal} / \mathrm{min}$ ), and most references to the use of specific capacity for estimating well yield are for high-yielding wells used for public water supply or industry. PaDEP needs to know the degree to which factors other than mining can affect the reproducibility of specific-capacity tests in the fracturedrock aquifers near areas of active coal mining or quarrying. Such information would allow a better assessment of the assumptions inherent in the procedure for determining preand post-mining yield of a well with specific-capacity values, provide a basis for a better understanding of the variability of specific-capacity test results on a single well and the conditions responsible for this variability, and result in better interpretations of pumping-test data. To address this need the U.S. Geological Survey (USGS), in cooperation with the PaDEP, Bureau of Mining and Reclamation, evaluated the reproducibility of specific-capacity values derived from pumping of low-yielding wells.

\section{Purpose and Scope}

This report describes the results of a study, in cooperation with the PaDEP, Bureau of Mining and Reclamation, to evaluate factors affecting the application of specific-capacity tests in six low-yielding water wells in areas of coal mining or quarrying in Pennsylvania. Factors affecting specific capacity such as pumping rate, duration of pumping, aquifer properties, wellbore storage, and turbulent-flow well losses were assessed by theoretical analysis and by completing multiple tests at differing rates and durations at six low-yielding wells during 2007-09 (fig. 1). Pumping each well was done to determine specific capacity, and geophysical logging and video surveys were done to determine the depth, casing length, and location of water-yielding zones in each of the test wells. Seasonal water-level changes were measured by continuous monitoring at each well.

\section{Fractured-Bedrock Aquifers}

The wells selected for study were completed in fractured siliciclastic or carbonate-bedrock aquifers in mining areas. Five wells are in shale, siltstone, sandstone, limestone, and coal of Pennsylvanian and Permian age in the bituminous coal fields of western Pennsylvania and one is in carbonate rocks (limestone of Cambrian age) in south-central Pennsylvania that are quarried for industrial uses.

Siliciclastic rocks of the bituminous coal fields of western Pennsylvania yield water to wells mostly through fractures because the primary permeability of the rock matrix is small. These fractured rocks create a complex, heterogeneous aquifer that is not easily classified as confined or unconfined. Callaghan and others (1998, p. 2-11) describe the groundwater flow system in the bituminous coal area as a "shallow, unconfined (possibly including seasonally perched or semi-perched zones) system grading to a semi-confined system at intermediate depth."

Carbonate rocks in south-central Pennsylvania yield water to wells from fractures (some widened by dissolution) and voids (Taylor and Werkheiser, 1984, p. 32). Wells in carbonate-rock aquifers are capable of producing thousands of gallons per minute, but yields vary widely depending if the well intercepts a permeable feature. Low yields are not uncommon when a well is drilled through only solid bedrock.

The water-yielding zones described in drilling logs of the bedrock aquifers represent one or more fractures containing groundwater. The water level in a well typically represents a composite hydraulic head of all the water-yielding fractures intersected by the well. The maximum yield of a well depends largely on how the water-yielding fractures are interconnected with other fractures outside the near-well environment. Fractures or voids that are not well connected may provide some water from storage, but cannot provide a sustained source of water to the well. 


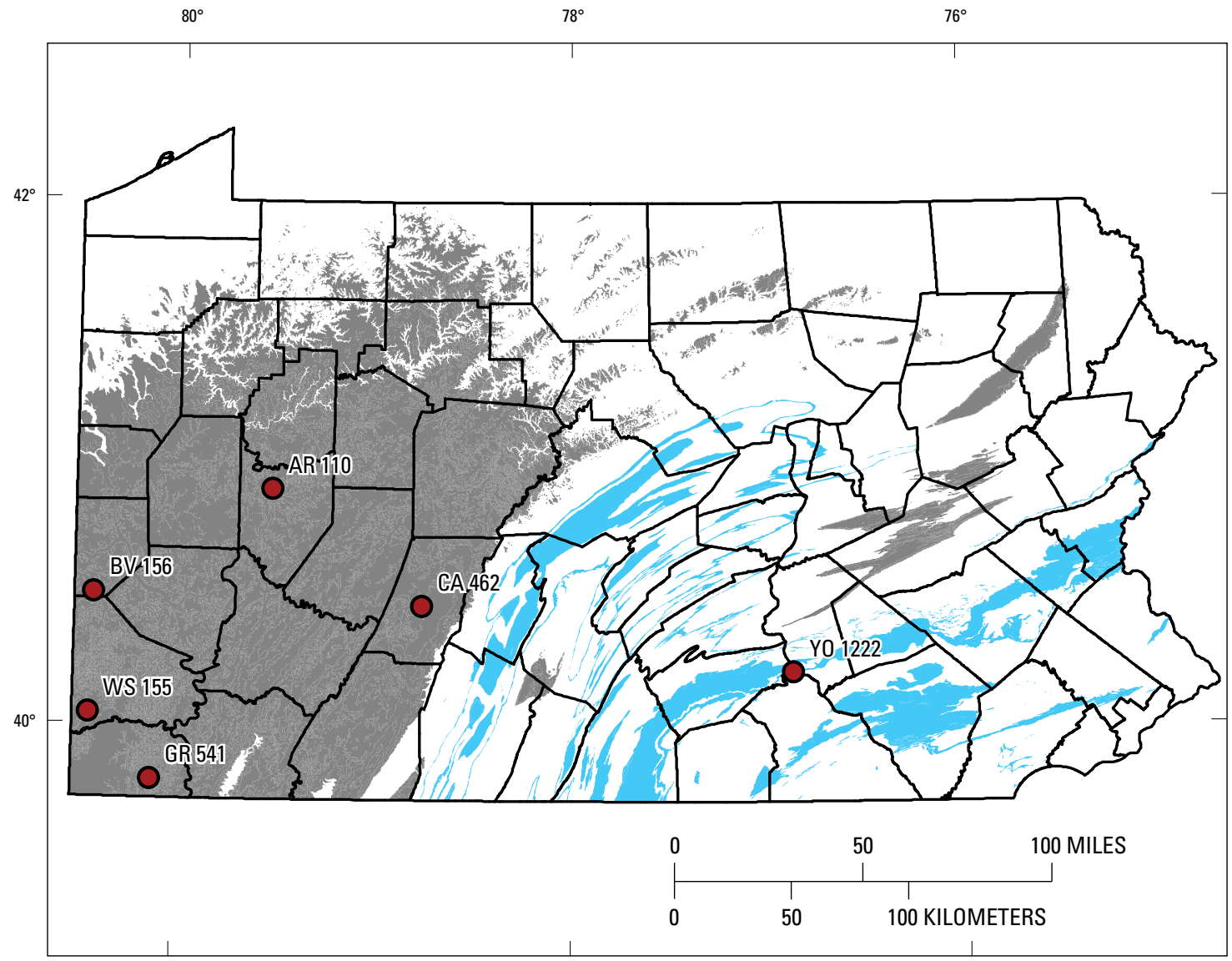

\section{EXPLANATION}

Coal-bearing rocks

Carbonate rocks

Well with identifier-Specific-capacity test for this study

Figure 1. Location of six low-yielding wells in fractured-bedrock aquifers in areas of coal or carbonate-rock mining in Pennsylvania selected for testing for this study. 


\section{Specific Capacity}

Specific capacity of a well is defined as the pumping rate divided by drawdown at some time after pumping was started (Lohman and others, 1972, p. 11):

$$
S C=Q / s,
$$

where

$S C \quad$ is specific capacity, in (gallons per minute) per foot;

$Q \quad$ is the pumping rate, in gallons per minute; and

$s \quad$ is drawdown in the pumped well, in feet;

and

$$
s=d-d_{0},
$$

where

$$
\begin{aligned}
& d \text { is the depth to water in the well, in feet; and } \\
& d_{0} \text { is the static depth to water when pumping } \\
& \text { begins, in feet. }
\end{aligned}
$$

Thus, for a given pumping rate $Q$, any factor affecting drawdown $s$ also will affect the value of specific capacity. Therefore, the accuracy and reproducibility of specific capacity for well evaluation depends on accurate field measurements of pumping rate and drawdown, and on control of the factors (other than mining influences) that affect drawdown.

Drawdown in a well is a function of laminar and turbulent flow in the aquifer and in the well. Under conditions of laminar radial flow in an ideal confined aquifer, the drawdown in a pumped well having negligible wellbore storage is given by Cooper and Jacob (1946) for all but early time as:

$$
s=\frac{35.3 Q}{T} \log \left(\frac{0.3 T t}{r^{2} S}\right)
$$

where

$T \quad$ is transmissivity, in square feet per day;

$t \quad$ is time since pumping began, in days;

$r \quad$ is the radius of the pumped well, in feet; and

$S \quad$ is the storage coefficient (dimensionless).

Note: the constant 35.3 accounts for the conversion of units of $Q$ in gallons per minute to cubic feet per day.
The drawdown caused by laminar flow is directly proportional to the pumping rate $Q$ (eq. 3). Thus, if all drawdown were caused by laminar flow, the specific capacity from two tests at different rates would not be affected by pumping rate because the numerator and denominator on the right-hand side of (eq. 1) would both differ proportionately. The overall magnitude of drawdown is inversely proportional to aquifer transmissivity. The change of drawdown in time is determined by the logarithm of the dimensionless time, which is the term inside the parentheses in (eq. 3). The dimensionless time is directly proportional to time and aquifer transmissivity and inversely proportional to the storage coefficient and the square of the radius of the pumped well.

Turbulent flow can increase the total drawdown in the well (fig. 2). The laminar $B Q$ and turbulent $C Q^{2}$ components of drawdown in the aquifer and the well are shown in the formula of Jacob (1947) as:

$$
s=B Q+C Q^{2},
$$

where

$B$ is the laminar-flow factor (equal to terms on the right-hand side of equation 3 ), in feet per (gallons per minute); and

$C \quad$ is the turbulent-flow factor, in feet per (gallon per minute) squared.

Drawdown from turbulent flow $C Q^{2}$ is not directly proportional to the pumping rate (as is drawdown from laminar flow); thus, specific-capacity values of tests completed at different pumping rates are different during turbulent flow. Fortunately, for pumping at low rates in low-yielding wells, drawdown from turbulent flow is usually small compared to drawdown caused by laminar flow.

A major factor affecting drawdown in low-yielding wells during short-duration tests is the water stored in the well bore. The "wellbore storage" can substantially lessen the drawdown (and increase specific capacity) in early parts of a specificcapacity test compared to predictions based on the assumption of negligible wellbore storage used in equation 3 . 


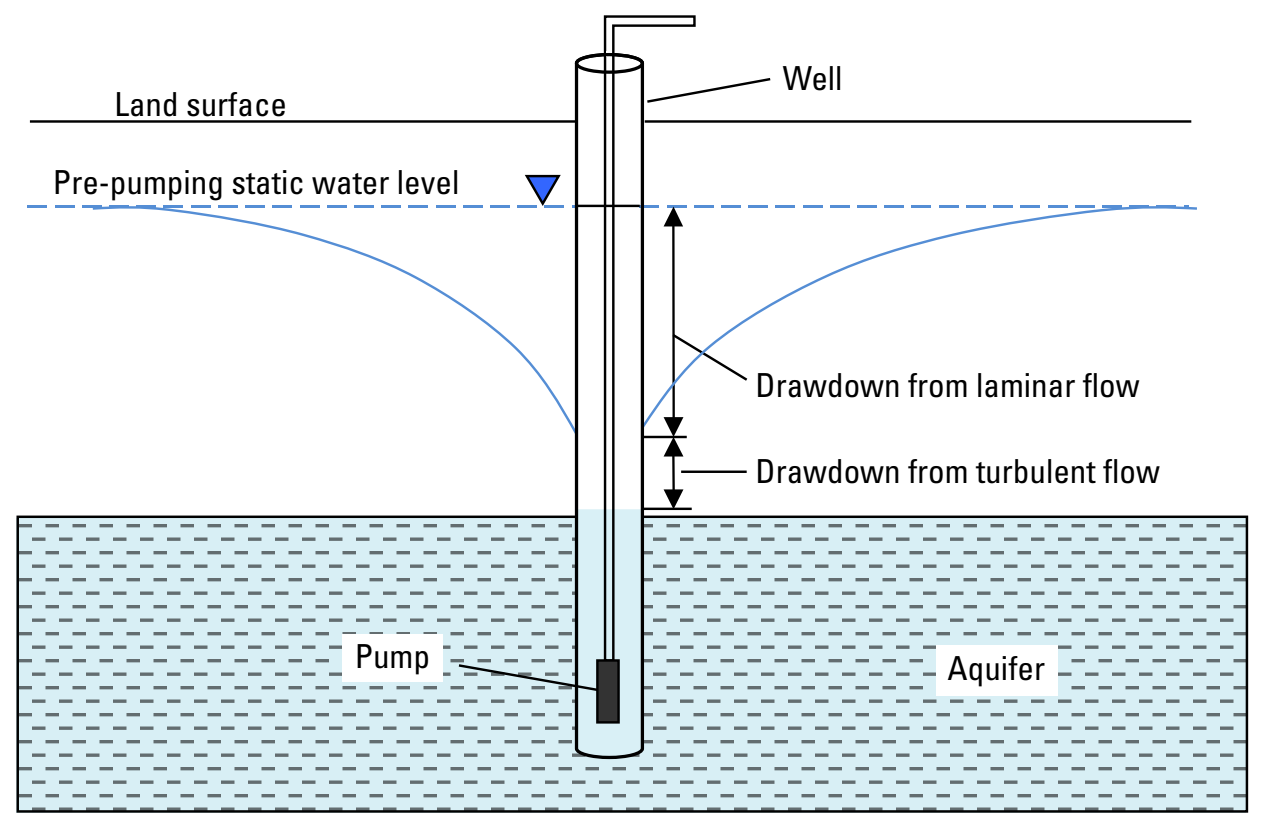

Figure 2. Schematic of components of drawdown caused by laminar $(B Q)$ and turbulent $\left(C Q^{2}\right)$ flow of water to a pumped well in an ideal confined aquifer. 


\section{Methods of Study}

The evaluation of short-duration specific-capacity tests was done by pumping wells in the field and by theoretical analysis. Water levels in the pumped wells were monitored during 2007-09 and downhole geophysical logs and videos were collected.

\section{Specific-Capacity Tests}

Six wells, mostly in coal-mining areas, were selected for pumping to evaluate the reproducibility of specific capacity for tests in the same well at different times and to examine the factors affecting reproducibility of results. Five of the wells were in siliciclastic rocks of mixed lithologies in the bituminous coal area of western Pennsylvania and one well was in carbonate rocks in south-central Pennsylvania (fig. 1).

Wells were selected to be representative of low-yielding household-supply wells in areas of active coal mining or quarrying. Typical household-supply wells in Pennsylvania are usually 6- or 8-in. diameter wells, cased from 20 to $40 \mathrm{ft}$ below land surface, and completed as open holes in bedrock at depths less than $300 \mathrm{ft}$. Unlike household-supply wells, the six wells selected for this study were unused at the time of testing. Unused wells allowed unobstructed access for experimentation throughout the study period. The wells were selected from a set of candidate wells that were either known or reported to yield less than about $5 \mathrm{gal} / \mathrm{min}$. One well is owned by a coal company, one is privately owned, and four are USGS observation wells. Characteristics of the wells are shown in table 1.

Twenty-four specific-capacity tests were completed at the six wells in various seasons from August 16, 2007, to September 21, 2009, and data were available from five tests completed on four of the wells prior to this study (table 2). The wells were pumped at rates ranging from $0.57-14 \mathrm{gal} / \mathrm{min}$ and durations of 22 to 240 minutes to demonstrate, in practice, how those factors could affect the reproducibility of specificcapacity values. Drawdown was monitored with a vented pressure transducer (Freeman and others, 2004) and check measurements were made periodically with a graduated electric tape. Discharge was monitored with either a recording paddlewheel flowmeter or a non-recording flowmeter, which was read every few minutes during the test. Flowmeter readings were checked periodically during the tests with a volumetric measurement by using a 5-gal bucket and stopwatch. Some of the specific-capacity tests were completed with the use of a device called the WellTender, which includes a flowmeter, pump controller, and data logger in a single unit capable of automatically holding the pumping rate of the Grundfos RediFlo2 pump steady during the duration of pumping. The steady pumping rate made it easier to evaluate how factors other than the pumping rate affect specific capacity.

Table 1. Characteristics of six low-yielding wells in fractured-rock aquifers in Pennsylvania.

[Borehole-video surveys were conducted at all wells. All wells were cased with steel casing. USGS, U.S. Geological Survey; ft, foot; in., inch; ss, sandstone; st, siltstone; sh, shale; md, mudstone; 1s, limestone; gal/min, gallon per minute; @, at]

\begin{tabular}{|c|c|c|c|c|c|c|}
\hline $\begin{array}{c}\text { Characteristics } \\
\text { USGS Well Identifier }\end{array}$ & \multicolumn{6}{|c|}{ Well } \\
\hline County & Armstrong & Beaver & Cambria & Greene & Washington & York \\
\hline $\begin{array}{l}\text { Latitude } \\
\text { Longitude }\end{array}$ & $\begin{array}{l}40^{\circ} 54^{\prime} 13.6^{\prime \prime} \\
79^{\circ} 31^{\prime} 25.7^{\prime \prime}\end{array}$ & $\begin{array}{l}40^{\circ} 30^{\prime} 06^{\prime \prime} \\
80^{\circ} 25^{\prime} 22^{\prime \prime}\end{array}$ & $\begin{array}{l}40^{\circ} 27^{\prime} 44.8^{\prime \prime} \\
78^{\circ} 45^{\prime} 32.5^{\prime \prime}\end{array}$ & $\begin{array}{l}39^{\circ} 47^{\prime} 38^{\prime \prime} \\
80^{\circ} 07^{\prime} 20^{\prime \prime}\end{array}$ & $\begin{array}{l}40^{\circ} 02^{\prime} 33^{\prime \prime} \\
80^{\circ} 26^{\prime} 12^{\prime \prime}\end{array}$ & $\begin{array}{l}40^{\circ} 12^{\prime} 50.24^{\prime \prime} \\
76^{\circ} 52^{\prime} 24.99^{\prime \prime}\end{array}$ \\
\hline Owner & Coal Company & USGS & USGS & Private & USGS & USGS \\
\hline Date drilled & 1999 & 1967 & 2008 & pre 1980 & 1971 & 2001 \\
\hline Well depth (ft) & 198 & 101 & 142 & 62 & 133 & 202 \\
\hline Casing inside diameter (in.) & 6 & 6.25 & 6 & 6 & 6 & 6.25 \\
\hline Casing length (ft) & ${ }^{1} 49$ & 25 & 17 & 20 & 19 & 18 \\
\hline Geologic unit & $\begin{array}{l}\text { Allegheny } \\
\text { Formation }\end{array}$ & $\begin{array}{l}\text { Glenshaw } \\
\text { Formation }\end{array}$ & $\begin{array}{l}\text { Glenshaw } \\
\text { Formation }\end{array}$ & $\begin{array}{l}\text { Washington } \\
\text { Formation }\end{array}$ & $\begin{array}{l}\text { Washington } \\
\text { Formation }\end{array}$ & $\begin{array}{l}\text { Epler } \\
\text { Formation }\end{array}$ \\
\hline Geophysical logs & no & yes & yes & yes & yes & yes \\
\hline
\end{tabular}

\footnotetext{
${ }^{1}$ An inner plastic 4 -in. casing is hanging in the well from about $5 \mathrm{ft}$ below land surface to a depth of $90 \mathrm{ft}$ below land surface.
} 
Table 2. Summary of results from multiple specific-capacity tests completed at six low-yielding wells in fractured-bedrock aquifers in Pennsylvania.

[min, minute; ft, foot; (gal/min)/ft, gallon per minute per foot; gal/min, gallon per minute; --, no data]

\begin{tabular}{|c|c|c|c|c|c|c|c|c|}
\hline \multirow{2}{*}{ Well } & \multirow{2}{*}{ Date } & \multirow{2}{*}{$\begin{array}{l}\text { Pumping } \\
\text { rate } \\
\text { (gal } / \mathrm{min})\end{array}$} & \multirow{2}{*}{$\begin{array}{l}\text { Duration of } \\
\text { pumping } \\
\text { (min) }\end{array}$} & \multirow{2}{*}{$\begin{array}{l}\text { Drawdown } \\
\text { at end of } \\
\text { test } \\
\text { (ft) }\end{array}$} & \multicolumn{3}{|c|}{$\begin{array}{c}\text { Specific capacity } \\
{[(\mathrm{gal} / \mathrm{min}) / \mathrm{ft}]}\end{array}$} & \multirow{2}{*}{ Comments } \\
\hline & & & & & At $60 \mathrm{~min}$ & At $180 \mathrm{~min}$ & $\begin{array}{l}\text { At end } \\
\text { of test }\end{array}$ & \\
\hline AR 110 & 05-17-1999 & 3.5 & 60 & 47 & 0.074 & -- & 0.074 & $\begin{array}{l}\text { Historical test. Specific capacity at } 49 \mathrm{~min}= \\
0.088(\mathrm{gal} / \mathrm{min}) / \mathrm{ft}\end{array}$ \\
\hline AR 110 & 09-01-1999 & 2.0 & 60 & 42 & .048 & -- & .048 & $\begin{array}{l}\text { Historical test. Specific capacity at } 49 \mathrm{~min}= \\
0.088(\mathrm{gal} / \mathrm{min}) / \mathrm{ft}\end{array}$ \\
\hline AR 110 & $03-12-2008$ & 2.0 & 55 & 63.2 & -- & -- & .032 & $\begin{array}{l}\text { Specific capacity at } 49 \mathrm{~min}= \\
0.035(\mathrm{gal} / \mathrm{min}) / \mathrm{ft}\end{array}$ \\
\hline AR 110 & $07-24-2008$ & 2.0 & 49 & 62.5 & -- & -- & .032 & $\begin{array}{l}\text { Pumped until water level reached transducer } \\
\text { depth. }\end{array}$ \\
\hline AR 110 & 05-27-2009 & .88 & 60 & 31.1 & .028 & -- & .028 & $\begin{array}{l}\text { Specific capacity at } 49 \mathrm{~min}= \\
0.034(\mathrm{gal} / \mathrm{min}) / \mathrm{ft}\end{array}$ \\
\hline BV 156 & 01-29-1969 & 7.9 & 60 & 81 & .100 & -- & .10 & Historical test \\
\hline BV 156 & $05-21-2008$ & 2.5 & 69 & 14.6 & .27 & -- & .17 & \\
\hline BV 156 & 05-21-2008 & 5.0 & 180 & 43.8 & .17 & 0.11 & .11 & $\begin{array}{l}\text { Began pumping } 1 \text { hour } 47 \mathrm{~min} \text { after end of } \\
2.5 \mathrm{gal} / \mathrm{min} \text { test. }\end{array}$ \\
\hline BV 156 & $07-23-2008$ & 5.0 & 180 & 37.8 & .19 & .13 & .13 & \\
\hline CA 462 & 03-11-2008 & 2.0 & 180 & 109.5 & .047 & .019 & .02 & \\
\hline CA 462 & $08-12-2008$ & 2.0 & 180 & 89.1 & .058 & .022 & .02 & \\
\hline CA 462 & $05-26-2009$ & 1.0 & 180 & 10.7 & .12 & .099 & .10 & \\
\hline CA 462 & 09-21-2009 & 1.1 & 180 & 7.8 & .15 & .14 & .14 & \\
\hline CA 462 & 09-21-2009 & 4.5 & 45 & 89.8 & -- & -- & .050 & $\begin{array}{l}\text { Began pumping } 1 \text { hour after end of } \\
1.05 \mathrm{gal} / \mathrm{min} \text { test. Pumped un- } \\
\text { til water level reached transducer } \\
\text { depth. Estimated specific capacity at } \\
60 \mathrm{~min}=0.01(\mathrm{gal} / \mathrm{min}) / \mathrm{ft}\end{array}$ \\
\hline GR 541 & $04-15-1980$ & .88 & 130 & 23.1 & .059 & -- & .038 & Historical test \\
\hline GR 541 & 07-23-2008 & 1.5 & 70 & 22.3 & .096 & -- & .067 & $\begin{array}{l}\text { Pumped until water level reached trans- } \\
\text { ducer depth. Flowmeter malfunc- } \\
\text { tioned, pumping rate from volumetric } \\
\text { measurements. Specific capacity at } \\
50 \mathrm{~min}=0.10(\mathrm{gal} / \mathrm{min}) / \mathrm{ft}\end{array}$ \\
\hline GR 541 & $11-25-2008$ & 1.5 & 50 & 16.5 & -- & -- & .091 & $\begin{array}{l}\text { Pumped until water level reached transducer } \\
\text { depth. }\end{array}$ \\
\hline GR 541 & 05-28-2009 & .57 & 60 & 6.1 & .094 & -- & .094 & $\begin{array}{l}\text { Specific capacity at } 50 \mathrm{~min}= \\
0.11(\mathrm{gal} / \mathrm{min}) / \mathrm{ft}\end{array}$ \\
\hline WS 155 & 07-01-1971 & 2.0 & 90 & 17 & .29 & & .12 & Historical test \\
\hline WS 155 & 03-13-2008 & 2.5 & 180 & 17.8 & .37 & 0.14 & .14 & \\
\hline WS 155 & $07-22-2008$ & 2.5 & 180 & 15.8 & .41 & 0.16 & .16 & \\
\hline WS 155 & $05-27-2009$ & 1.0 & 60 & 2.9 & .34 & -- & .34 & \\
\hline WS 155 & 05-27-2009 & 6.0 & 35 & 36.5 & -- & -- & .16 & $\begin{array}{l}\text { Began pumping } 60 \text { minutes after end of } \\
1 \mathrm{gal} / \mathrm{min} \text { test. Pumped until water level } \\
\text { reached transducer depth. }\end{array}$ \\
\hline YO 1222 & $08-16-2007$ & 2.0 & 60 & 24 & .083 & -- & .083 & \\
\hline YO 1222 & $08-22-2007$ & 6.0 & 63 & 1.2 & 5.1 & -- & 5.00 & \\
\hline YO 1222 & 03-10-2008 & 5.0 & 180 & 1.2 & 5.5 & 4.20 & 4.20 & \\
\hline YO 1222 & $07-18-2008$ & 2.1 & 180 & 17.3 & .12 & .12 & .12 & \\
\hline YO 1222 & 08-07-2008 & 2.0 & 240 & 46.3 & .11 & .11 & .11 & $\begin{array}{l}\text { Step-drawdown test- } 60 \text {-min steps at } 2,3 \text {, } \\
\quad 4,5 \mathrm{gal} / \mathrm{min}\end{array}$ \\
\hline YO 1222 & 09-02-2009 & 14 & 22 & 116.6 & -- & -- & .12 & $\begin{array}{l}\text { Pumped until water level reached transducer } \\
\text { depth. }\end{array}$ \\
\hline
\end{tabular}




\section{Water-Level Monitoring}

Water levels were monitored with transducers or floats with digital encoders to establish the range of water-level fluctuation during the study period. Large seasonal water-level fluctuations have the potential to cause substantial changes in aquifer saturated thickness and, therefore, transmissivity, which would directly affect the specific capacity of the well.

Water-level hydrographs for all six wells that were pumped during the study are shown in figure 3. Dates at which specific-capacity tests were done are noted with a triangle.
Water-level fluctuations were less than $5 \mathrm{ft}$ during the study for all wells except YO 1222. The water level in this well, completed in carbonate bedrock, fluctuated about $17 \mathrm{ft}$ during the study and had rapid water-level fluctuations in response to storms. Seasonal changes ranged from about 2 to 10 percent of the saturated thickness of the aquifer open to the wells. The general decline in water levels in most of the wells from about March through September 2008 was caused by seasonal differences in groundwater recharge.

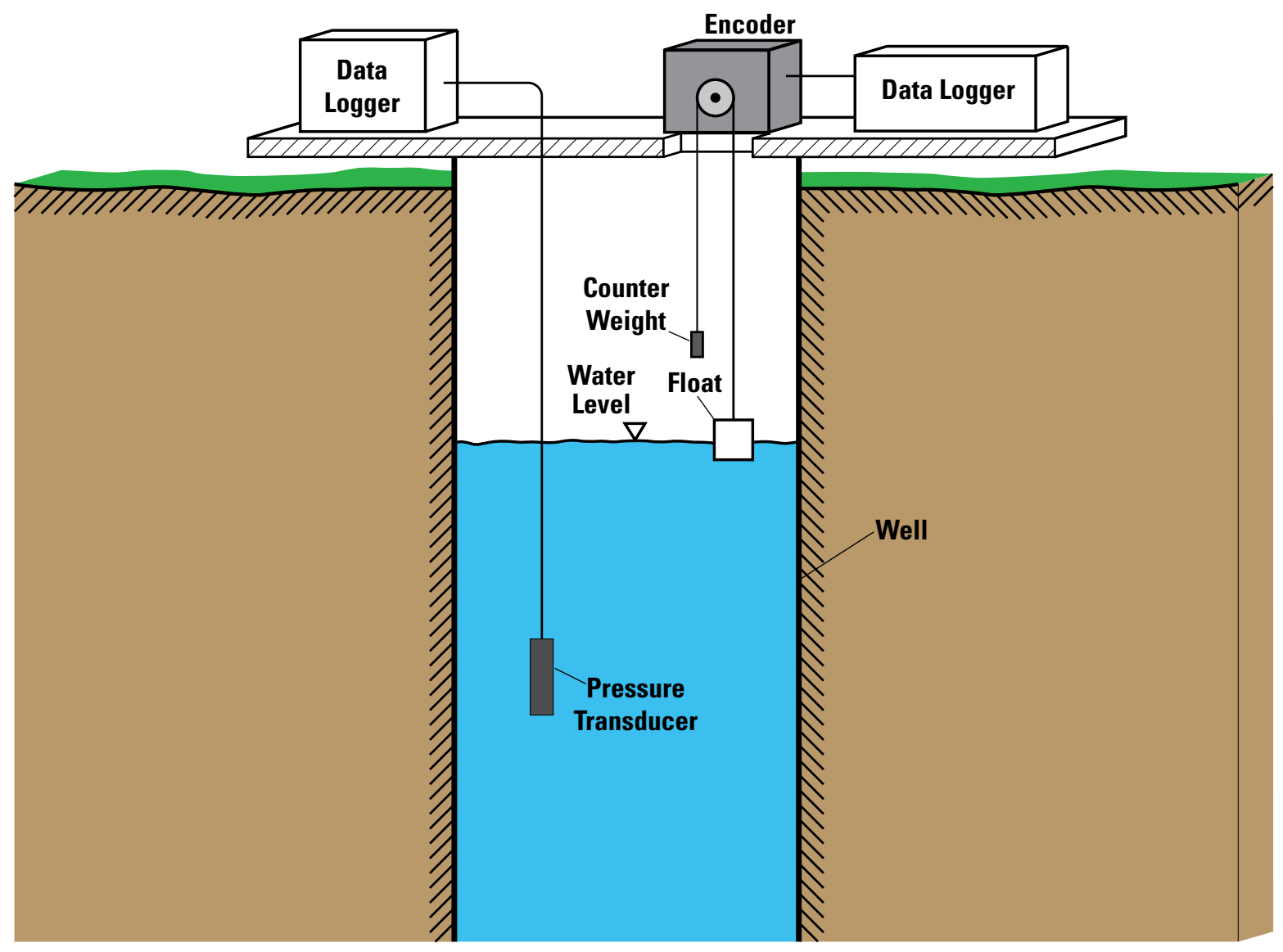

Water-level monitoring with transducer or float system. 

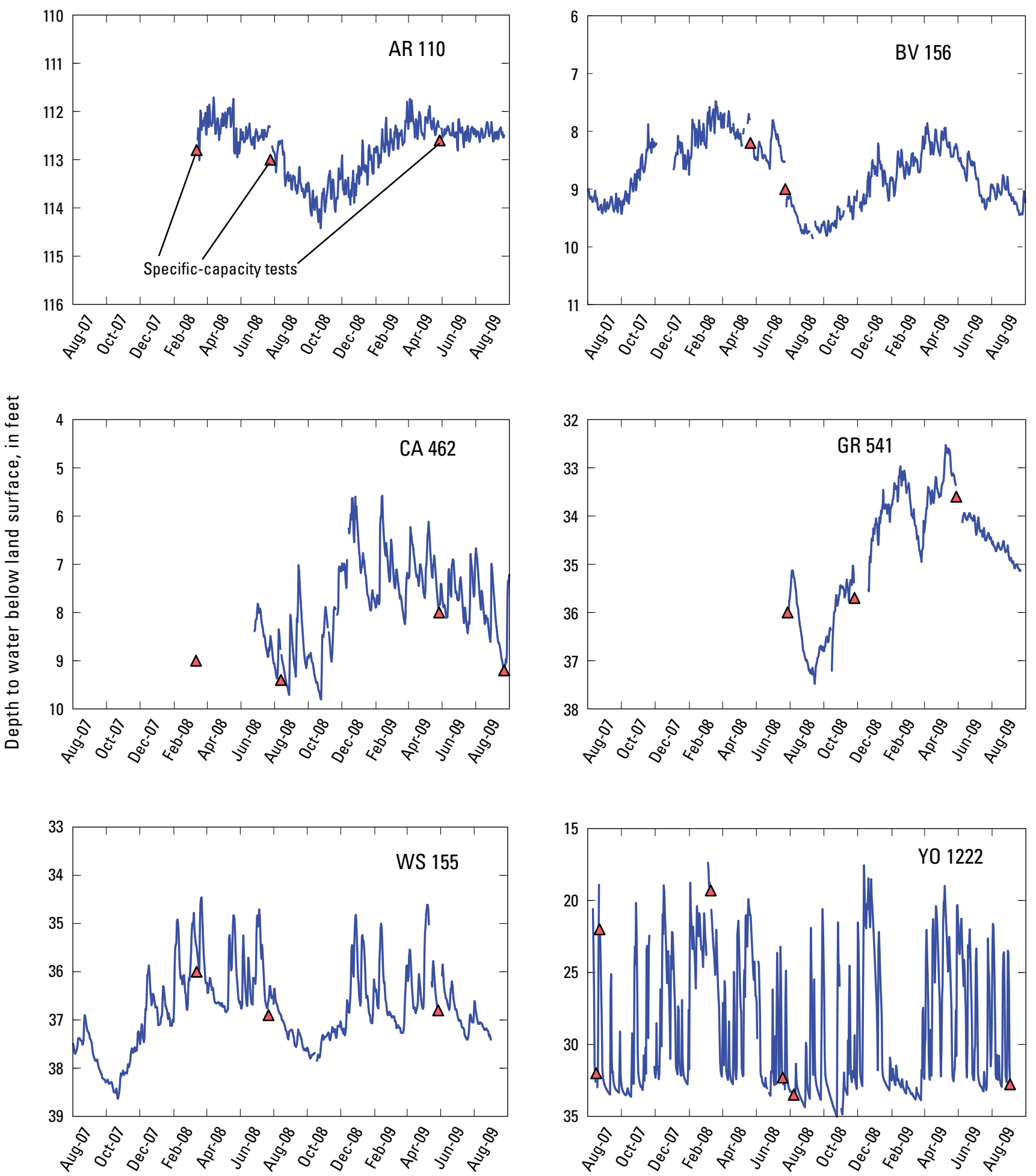

Figure 3. Water-level fluctuations and dates of pumping for six low-yielding wells in fractured-bedrock aquifers in Pennsylvania. 


\section{Geophysical Logging}

Geophysical and video surveys were completed at the six low-yielding wells in fractured-bedrock aquifers to verify well and casing diameter, casing length, and to determine the location of water-yielding zones. Those water-yielding zones identified by logging were associated with identified fractures or fracture sets in the bedrock. Geophysical logs that were useful for identifying water-yielding zones included: caliper, natural gamma, single-point resistance, fluid temperature, and fluid resistivity (Keys, 1990). Fluid flow in the well was measured by use of a heat-pulse flowmeter, which helped identify the major water-yielding zones by comparing vertical flow in the well when the well was pumped and when the well was idle (Keys, 1990, p. 130). A borehole video survey was completed in all wells to investigate the condition of the casing and examine possible clogging of water-yielding zones by chemical precipitates. The major water-yielding zones as determined from geophysical logging and driller reports are shown in figure 4. Examples of images from the borehole video showing fractures intersected by two wells are shown in figure 5 .

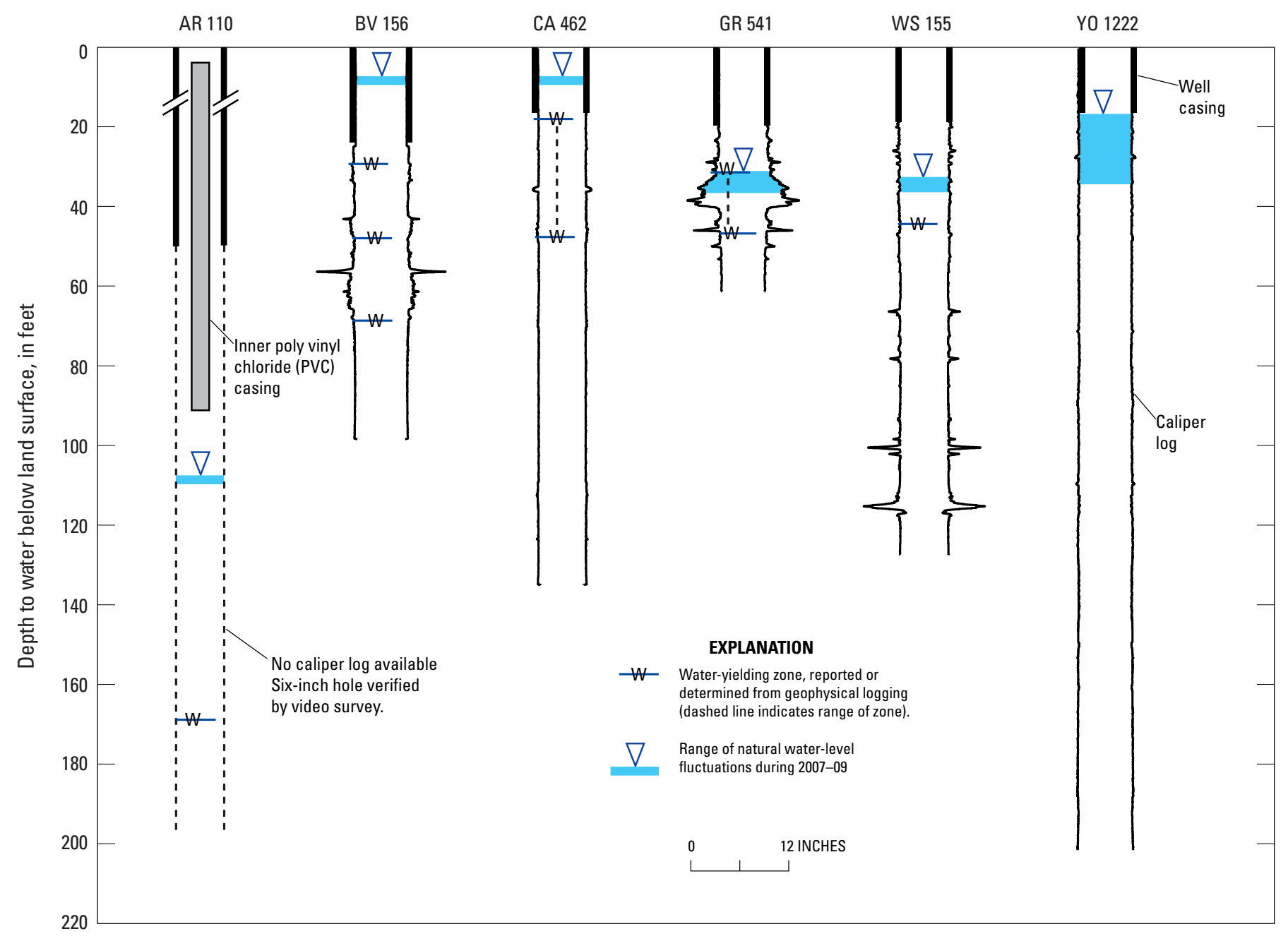

Figure 4. Variation in wellbore diameter (caliper log), range of natural water-level fluctuations 2007-09, and locations of major wateryielding zones as determined from geophysical logging and driller reports for six low-yielding wells in fractured-bedrock aquifers in Pennsylvania. 

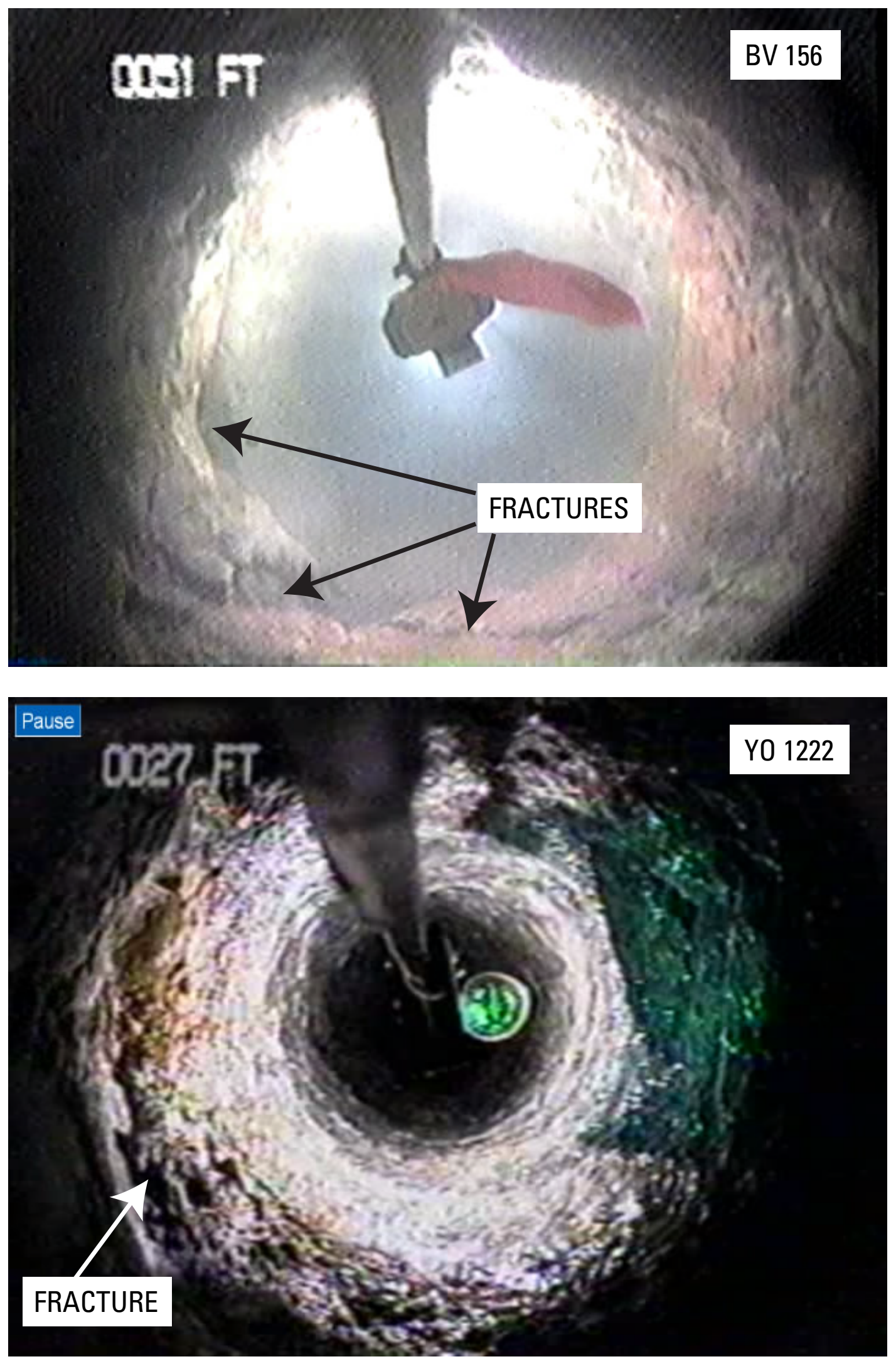

Figure 5. Images from the borehole video log showing fractures intersected by wells BV 156 and Y0 1222. 


\section{Specific-Capacity Tests at Six Low- Yielding Wells in Fractured Bedrock}

\section{Well AR 110}

Well AR 110 in Armstrong County is completed in fractured shale, sandstone, and coal of the Allegheny Formation to a depth of $198 \mathrm{ft}$ (table 1). The geologic log shows that the well penetrates disturbed spoil from the mining of the Middle Kittanning coal to a depth of $34 \mathrm{ft}$ and the Lower Kittanning coal from 74.5-77.5 ft below land surface. The well is cased with 6-in. diameter steel casing to $49 \mathrm{ft}$ below land surface, and an inner 4-in. diameter plastic liner hangs inside the steel casing from 5 to $90 \mathrm{ft}$ below land surface. One zone yielding $2.7 \mathrm{gal} / \mathrm{min}$ of water from gray sandy shale was reported on the geologic log at a depth of $167 \mathrm{ft}$ below land surface. The static water level in the well was deep-about $110 \mathrm{ft}$ below land surface (fig. 3), which allowed about $88 \mathrm{ft}$ of drawdown available for testing. Geophysical logging was not done at this well for this study.

Three specific-capacity tests were done by USGS at well AR 110 during 2008-09. The well was pumped twice at $2.0 \mathrm{gal} / \mathrm{min}$ and once at $0.88 \mathrm{gal} / \mathrm{min}$ (table 2). Results also were available from two tests completed at rates of 2.0 and $3.5 \mathrm{gal} / \mathrm{min}$ by a coal company in 1999 (Kenneth King, W.D. Mohney and Associates, written commun., 2008). The durations of the pumping were short for those tests, ranging from 49 to 60 minutes, because the water level in the well declined rapidly in response to pumping. Recovery was monitored for 60 to 120 minutes after each test completed by USGS. Drawdown and recovery of water levels from each test are shown in figure $6 \mathrm{~A}$. The change in specific capacity with time for each test is shown in figure 6B.

The most striking characteristic of the water-level drawdown and recovery curves during the specific-capacity tests

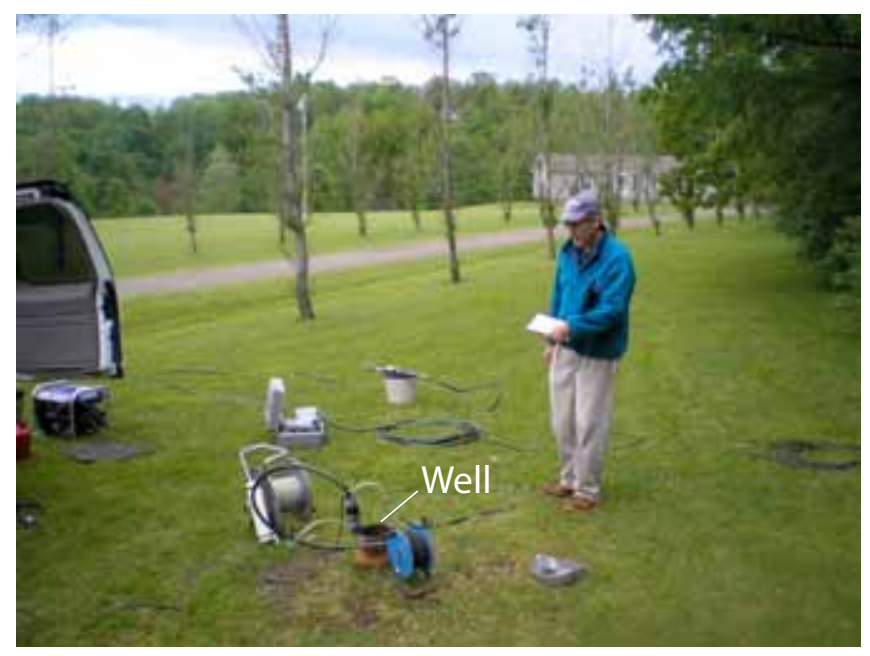

Specific-capacity testing at well AR 110. Photograph by Randall Conger, U.S. Geological Survey. completed during 2008-09 is that the data plot as straight lines on arithmetic axes (fig. 6A). The straight lines indicate that drawdown and recovery are proportional to time, and that most of the pumped water is derived either from water stored in the well and (or) from the aquifer at a rate independent of the water level in the well. The straight-line water-level decline during the pumping period indicates that the rate of withdrawal from wellbore storage was about $1.84 \mathrm{gal} / \mathrm{min}$; after pumping ceased, the water-level recovery curve indicates a constant inflow of about $0.2 \mathrm{gal} / \mathrm{min}$. Thus, the maximum well yield appears to be about only $0.2 \mathrm{gal} / \mathrm{min}$ for tests completed during 2008-09.

The two specific-capacity tests completed about 10 years previously in 1999 resulted in less drawdown and more rapid recovery than for the tests completed during 2008-09. The maximum well yield indicated by these tests is much greater than $0.2 \mathrm{gal} / \mathrm{min}$. The static water levels were about $10 \mathrm{ft}$ lower in 1999, therefore the greater yield cannot be explained by more saturated water-yielding zones connected to the well than in 2008-09. One possible explanation for the lower specific capacity in 2008-09 is that the water-yielding zone noted on the geologic log at $167 \mathrm{ft}$ below land surface has become clogged during the past 10 years. The video survey was unable to identify any obvious fractures at or near the depth of the reported water-yielding zone, therefore direct proof of plugged fractures could not be verified; however, the water in the well bore contained abundant particulate matter that was apparently dislodged from the wall of the well, indicating that clogging is a possibility.

The change in specific capacity with time for each test is shown in figure 6B. The specific-capacity values determined from the July 2008 test at $2 \mathrm{gal} / \mathrm{min}$ and May 2009 test at $0.88 \mathrm{gal} / \mathrm{min}$ were nearly identical. The March 2008 test completed at $2 \mathrm{gal} / \mathrm{min}$ gives similar values of specific capacity toward the end of the test, but deviates substantially during the early part of the test, because the pumping rate was initially not stable. 

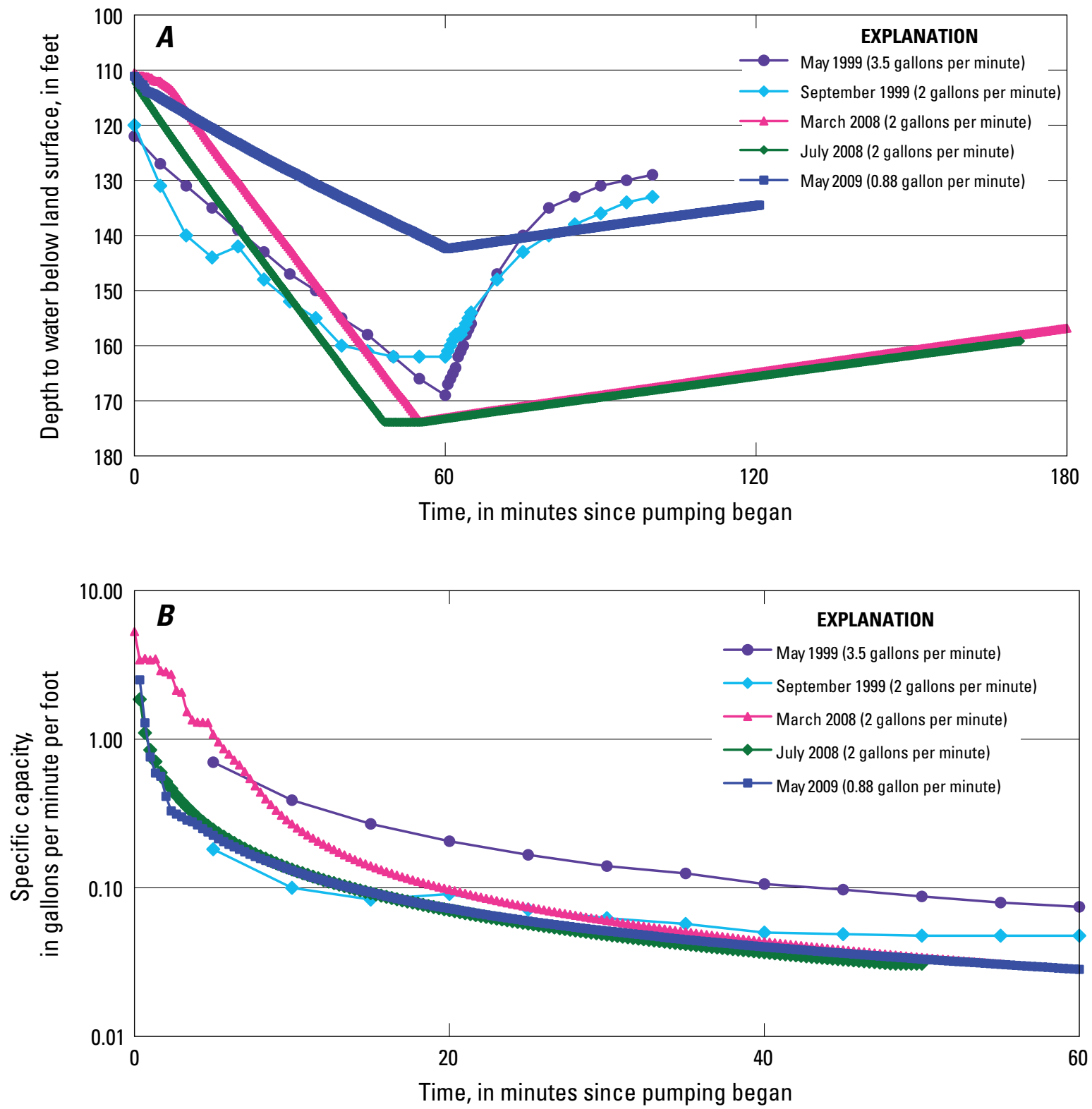

Figure 6 Water level $(A)$ and specific capacity $(B)$ during five specific-capacity tests at well AR 110 in Armstrong County, Pennsylvania. 


\section{Well BV 156}

Well BV 156 in Beaver County is an observation well, maintained and operated by USGS for monitoring drought conditions. The well is completed in shale, mudstone, and siltstone of the Glenshaw Formation to a depth of $101 \mathrm{ft}$ and is cased with 6.25-in. diameter steel casing to $25 \mathrm{ft}$ below land surface (table 1). The yields and the depths of the major wateryielding zones were reported by the driller as $0.5 \mathrm{gal} / \mathrm{min}$ at $30 \mathrm{ft}, 4 \mathrm{gal} / \mathrm{min}$ at $52 \mathrm{ft}$, and $6 \mathrm{gal} / \mathrm{min}$ at $67 \mathrm{ft}$ (table 1). The water-yielding zone at $52 \mathrm{ft}$ corresponds to a fracture shown on the video survey at $51 \mathrm{ft}$ below land surface (fig. 5). The zone at $67 \mathrm{ft}$ is at a lithologic contact between mudstone and siltstone, according to the log of cuttings from the well. Geophysical logging indicated a major opening at about $57 \mathrm{ft}$ below land surface (fig. 4). The flowmeter survey and temperature log indicated that the most productive water-yielding zone was at $30 \mathrm{ft}$, with additional yield contributed between 50 and $80 \mathrm{ft}$ below land surface, probably from fractures at 52 and $67 \mathrm{ft}$ below land surface. The static water level in the well was shallow-about $8 \mathrm{ft}$ below land surface (fig. 3), which allowed about $93 \mathrm{ft}$ of drawdown available for testing.

Well BV 156 was pumped on two occasions by USGS during 2008 (table 2). The well was pumped at $2.5 \mathrm{gal} / \mathrm{min}$

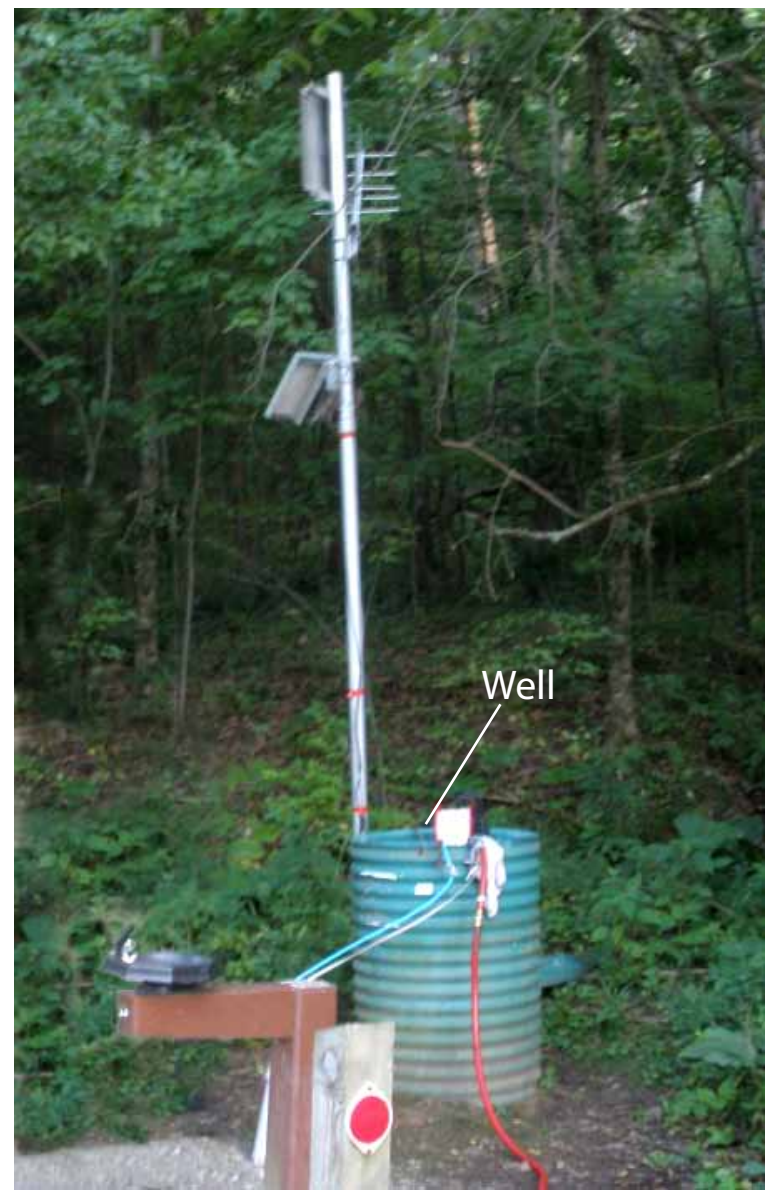

Specific-capacity testing at well BV 156, inside culvert pipe. Photograph by Brad Kuntz, U.S. Geological Survey for 69 minutes in May 2008, then the rate was increased to $5 \mathrm{gal} / \mathrm{min}$, but the pump failed after 6 minutes. The water level was allowed to recover for 101 minutes then the well was pumped again at $5.0 \mathrm{gal} / \mathrm{min}$ for 180 minutes. A specificcapacity test at $5 \mathrm{gal} / \mathrm{min}$ was repeated in July 2008. Recovery was monitored until the water level had nearly returned to the static pre-pumping levels. A 60-minute test also was completed by USGS in 1969 at a rate of $7.9 \mathrm{gal} / \mathrm{min}$.

Drawdown and recovery of water levels during the four tests are shown in figure 7A. The two specific-capacity tests completed at $5 \mathrm{gal} / \mathrm{min}$ showed similar curves for waterlevel drawdown and recovery. Drawdown was nearly steady after 69 minutes of pumping at $2.5 \mathrm{gal} / \mathrm{min}$ during the test in May 2008. The specific-capacity test in 1969 at $7.9 \mathrm{gal} / \mathrm{min}$ resulted in more drawdown than for the tests completed during 2008 for this study because of the greater pumping rate. The drawdown for the 1969 test stabilized for about 20 minutes at a depth of about $57 \mathrm{ft}$ below land surface. This depth corresponds to the depth of the opening shown on the caliper log (fig. 4). Possibly, a fracture is connected to a large void in the bedrock and this storage is being dewatered during this period, after which drawdown increased. The rate of drawdown increases after the water level is below this zone, indicating that this zone contributes some inflow, although it was not identified as a major water-yielding zone during logging. An inflection in the water-level curve at this depth can be seen during recovery.

The change in specific capacity with time for each test is shown in figure 7B. The specific-capacity values determined from the pumping at $5 \mathrm{gal} / \mathrm{min}$ in the May and July 2008 tests were nearly identical. The May 2008 test at $2.5 \mathrm{gal} / \mathrm{min}$ gives a greater value of specific capacity and nearly reaches equilibrium. Specific capacity was substantially less for the test completed at a rate of $7.9 \mathrm{gal} / \mathrm{min}$. The decrease in specific capacity with increased pumping rate could be explained by turbulent flow in the aquifer and well, but turbulent flow is probably not the major cause. The more likely explanation is that the greater pumping rates caused the water level in the well to draw down below one or more of the major wateryielding zones at 30,52 , and $67 \mathrm{ft}$ below land surface, thereby reducing the transmissivity of the aquifer near the well. The maximum yield for the well based on the tests completed in 2008 seems to be about $5 \mathrm{gal} / \mathrm{min}$. 

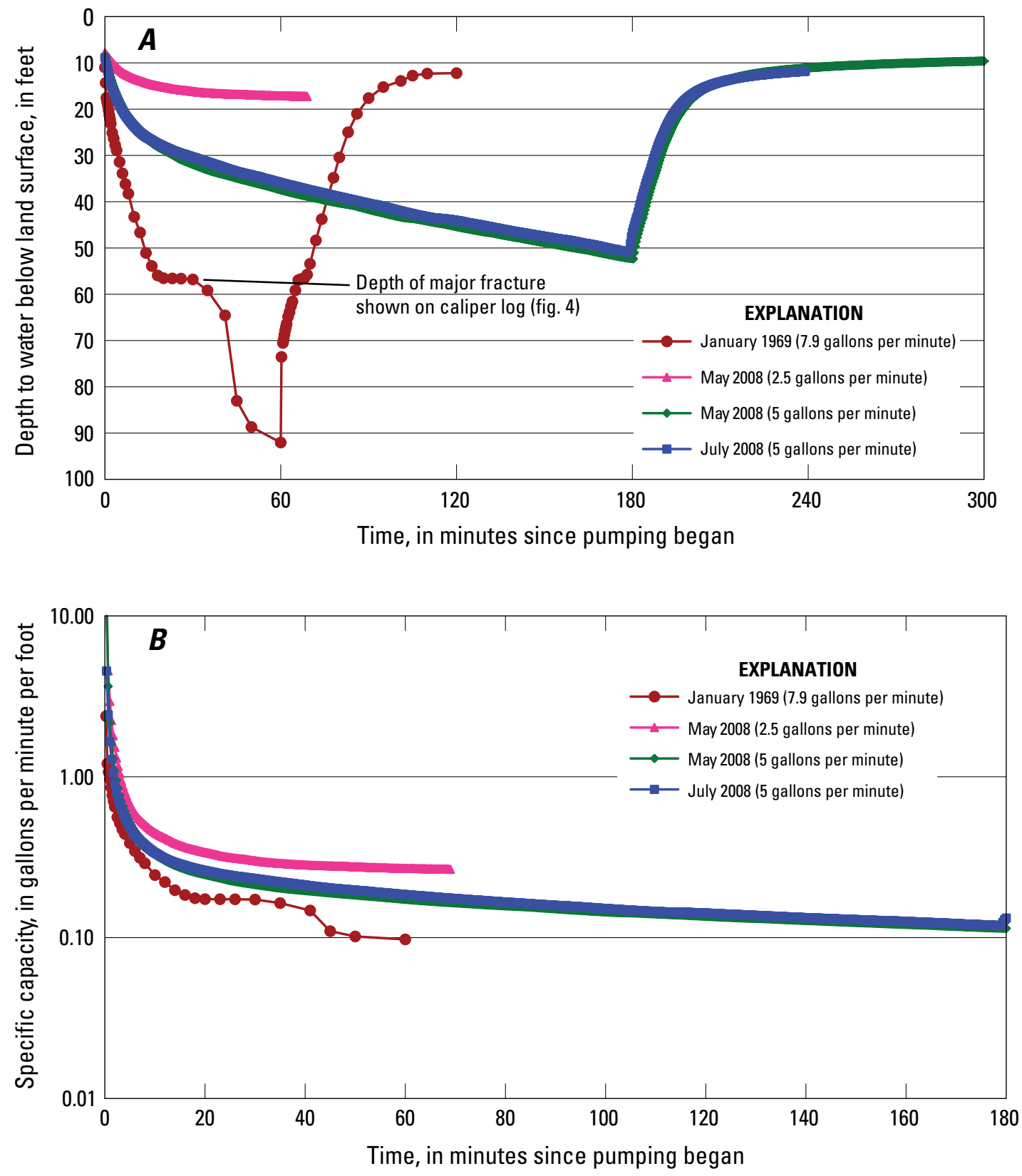

Figure 7. Water level $(A)$ and specific capacity $(B)$ during five specific-capacity tests at well BV 156 in Beaver County, Pennsylvania. 


\section{Well CA 462}

Well CA 462 in Cambria County is an observation well, maintained and operated by USGS for monitoring drought conditions. The well is completed in the Glenshaw Formation to a depth of $142 \mathrm{ft}$ and cased with 6-in. diameter steel casing to $17 \mathrm{ft}$ below land surface (table 1). The log of drill cuttings indicated that most of the well was drilled into gray sandstone with minor amounts of shale. A coal bed was noted at $27 \mathrm{ft}$ below land surface. The depths of the major water-yielding zones were not reported by the driller. Geophysical logging indicated a fracture at about $37 \mathrm{ft}$ below land surface (fig. 4), and the flowmeter survey indicated that most of the water is yielded from $17-50 \mathrm{ft}$ below land surface. The static water level in the well was shallow-ranging from about 6-10 ft below land surface (fig. 3), which allowed about $132 \mathrm{ft}$ of drawdown available for testing.

Well CA 462 was pumped on four occasions by USGS during 2008-09 (table 2). The well was pumped at $2 \mathrm{gal} / \mathrm{min}$ for 180 minutes in March and August 2008 and then allowed to recover for 120 minutes. The well was pumped at $1.0 \mathrm{gal} / \mathrm{min}$ for 180 minutes in May 2009, and the static water level recovered after about 60 minutes. The well was pumped at $1.1 \mathrm{gal} / \mathrm{min}$ in September 2009, allowed to recover for 60 minutes, and pumped again at $4.5 \mathrm{gal} / \mathrm{min}$ for 45 minutes.

Drawdown and recovery of water levels for the five tests are shown in figure 8A. Similar to the results from tests at AR 110, drawdown for the tests completed at 2.0 and $4.5 \mathrm{gal} / \mathrm{min}$ plotted as straight lines on arithmetic axes. The straight lines show that the water-level change is proportional to time, and that most of the pumped water is being derived from water stored in the well and (or) water contributed from the aquifer at a constant rate. The straight-line waterlevel drawdown curves during pumping for the $2 \mathrm{gal} / \mathrm{min}$ tests starting after about 60 minutes indicate that the rate of withdrawal from wellbore storage was about $0.7-0.8 \mathrm{gal} / \mathrm{min}$

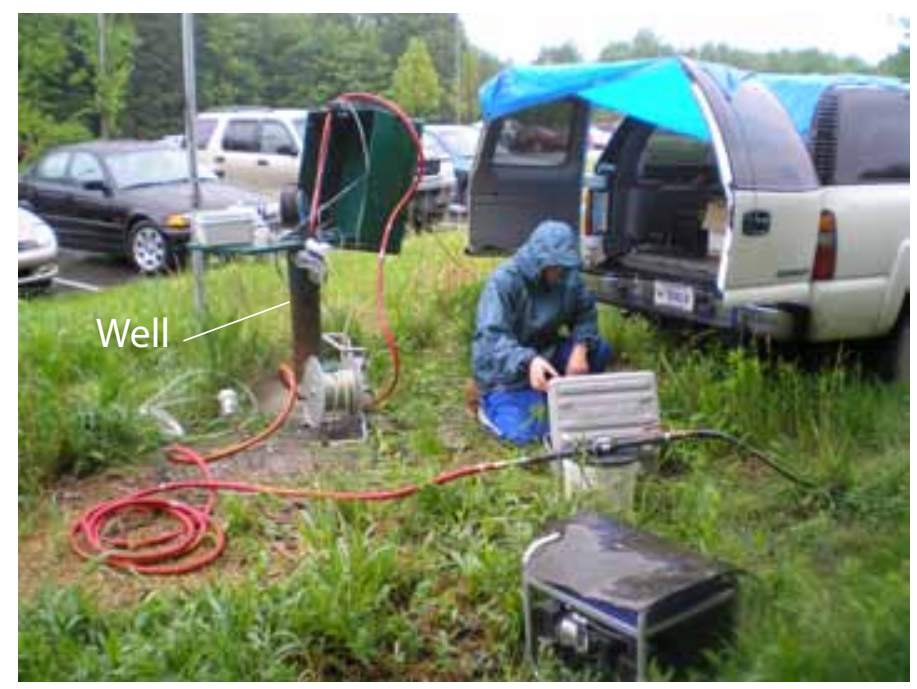

Specific-capacity testing at well CA 462. Photograph by Randall Conger, U.S. Geological Survey. (assuming a 6-in. diameter well); after cessation of pumping, the water-level recovery curves indicate a constant inflow of about $1.3 \mathrm{gal} / \mathrm{min}$. The straight-line curves for the $4.5 \mathrm{gal} / \mathrm{min}$ test indicate a constant inflow of about $1.5 \mathrm{gal} / \mathrm{min}$. Thus, the maximum well yield is about $1.3-1.5 \mathrm{gal} / \mathrm{min}$.

Water levels during the $1 \mathrm{gal} / \mathrm{min}$ tests in May and September 2009 reached an apparent equilibrium after about 120 minutes of pumping. Straight-line segments of waterlevel change observed during the other tests were not seen in these tests because the water level did not fall below the water-yielding zones from 17-50 ft below land surface. Both $1 \mathrm{gal} / \mathrm{min}$ tests recovered to static water level within an hour of the end of pumping. These tests verified that the well had a maximum yield of at least $1 \mathrm{gal} / \mathrm{min}$.

The change in specific capacity with time for each test is shown in figure $8 \mathrm{~B}$. The specific-capacity values determined from the pumping at $1.0 \mathrm{gal} / \mathrm{min}$ in May and September 2009 were similar, but not identical. The May and September tests reached an apparent equilibrium, but the specific capacity is greater for the September 2009 test. Specific capacity was substantially less for the tests completed at rates of 2.0 and $4.5 \mathrm{gal} / \mathrm{min}$. The decrease in specific capacity with increased pumping rate could be explained by turbulent flow in the aquifer and well, but turbulent flow is probably not the major cause. The more likely explanation is that the greater pumping rates caused the water level in the well to draw down below the water-yielding zones from 17-50 ft below land surface, thereby, decreasing the aquifer transmissivity.

The $2 \mathrm{gal} / \mathrm{min}$ test completed in August $2008 \mathrm{had}$ a greater specific capacity than the test in March 2008, and the specific capacity from the $1 \mathrm{gal} / \mathrm{min}$ test in September 2009 was greater than for the test at the similar rate in May 2009. The increase indicates that there may have been a slight development of the water-yielding fractures each time the well was pumped. 

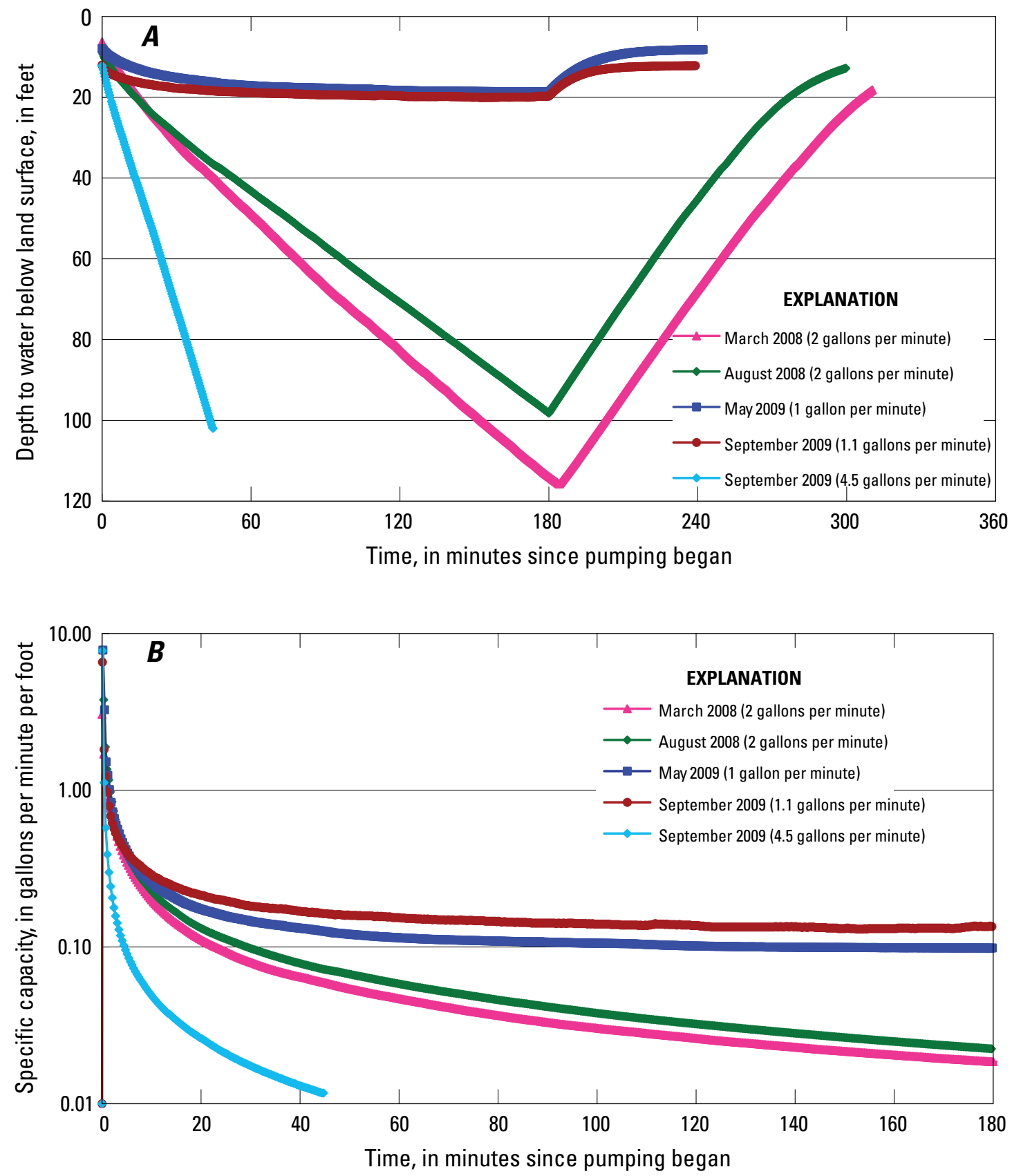

Figure 8. Water level $(A)$ and specific capacity $(B)$ during five specific-capacity tests at well CA 462 in Cambria County, Pennsylvania. 


\section{Well GR 541}

Well GR 541 in Greene County is a privately owned well that was used to monitor water levels for a study of groundwater in Greene County in the 1980s (Stoner and others, 1987), and is currently (2009) unused. The well is completed in sandstone, siltstone, and limestone of the Washington Formation to a depth of $62 \mathrm{ft}$ and cased with 6-in. diameter steel casing to $20 \mathrm{ft}$ below land surface (table 1). Limestone was reported on the USGS well schedule from 20-23 ft below land surface. A driller's report was not available, but geophysical logging indicated considerable variability in well diameter from 6 in. to more than 12 in. Major enlargements of the well diameter, probably caused by fractures, were detected at depths from $33-40,46$, and $50 \mathrm{ft}$ below land surface. Flowmeter surveys, though not definitive, indicated that water is probably contributed throughout the saturated thickness of the aquifer, with most of the water being yielded less than $50 \mathrm{ft}$ below land surface. The static water level in the well ranged from about 33-36 ft below land surface (fig. 3), which allowed only about $30 \mathrm{ft}$ of drawdown available for testing.

Well GR 541 was pumped on three occasions by USGS during 2008-09 (table 2). The well was pumped at $1.5 \mathrm{gal} / \mathrm{min}$ until the water level reached the depth of the transducer setting in July and November 2008 (after 70 and 50 min of pumping, respectively), then was allowed to recover for 120 minutes. The well was pumped at $0.57 \mathrm{gal} / \mathrm{min}$ for 60 minutes in May 2009 , and recovery was monitored for 60 minutes. Results also were available from a test completed by USGS in 1980 for 130 minutes at $0.88 \mathrm{gal} / \mathrm{min}$.

Drawdown and recovery of water levels for the four tests are shown in figure 9A. The curves for the tests completed at $1.5 \mathrm{gal} / \mathrm{min}$ are complex, showing multiple straight-line

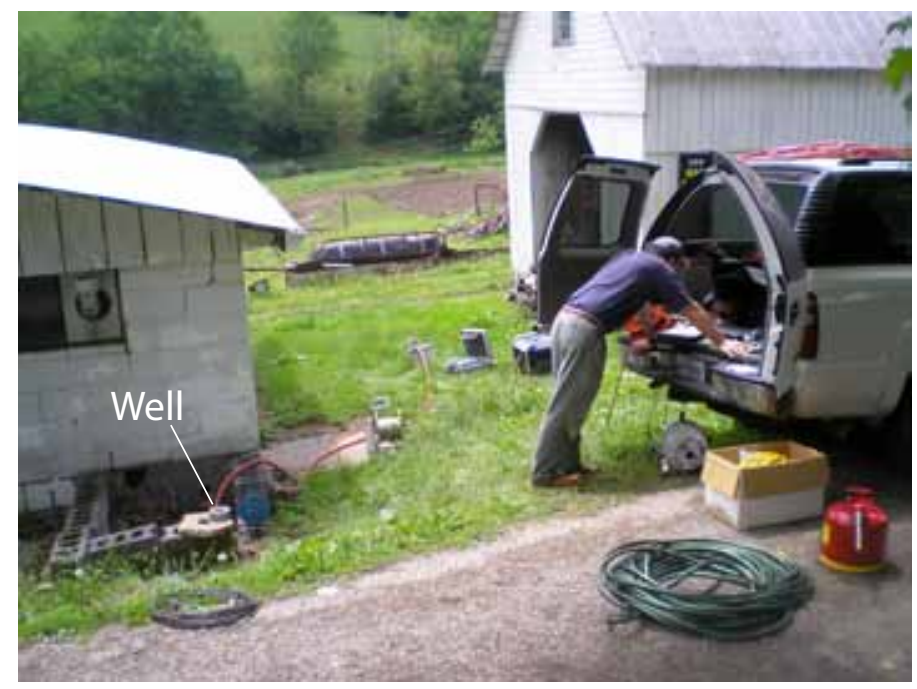

Specific-capacity testing at well GR 541, near shed. Photograph by Randall Conger, U.S. Geological Survey. segments of differing slopes. The breaks in slope seem to be caused by boundary conditions, but the multiple tests show that the breaks are not at the same time after pumping was started for each test; rather, the breaks are at the same waterlevel depths. The tests are nearly impossible to interpret without knowledge of the well diameter from the caliper log. The steepest sections of the curves correspond to smallest diameter sections of the well bore from 40-45, 47-49, and 51-53 ft below land surface. The flat sections of the water-level curves at depths of 46 and $50 \mathrm{ft}$ below land surface correspond to depths at which the well intersected enlarged fractures or voids. The slope of the drawdown and recovery curves change because most of the water being pumped is derived from storage in the well and voids. The voids provide water to the well from storage, but have small transmissivity as indicated by the slow recovery. The straight-line water-level curves for the last straight-line segment during drawdown and first segment of recovery from the $1.5 \mathrm{gal} / \mathrm{min}$ test in July 2008 , indicate a rate of constant inflow of about $0.5 \mathrm{gal} / \mathrm{min}$.

Drawdown from the $0.57 \mathrm{gal} / \mathrm{min}$ test in May 2009 did not reach an apparent equilibrium after 60 minutes of pumping and the recovery was slow. Probably the maximum yield is less than $0.5 \mathrm{gal} / \mathrm{min}$. Data for the test completed in April 1980 show that the static water level was about $10 \mathrm{ft}$ higher than for the other tests and that the water level stabilized at the same depth ( $46 \mathrm{ft}$ below land surface) as for the other $1.5 \mathrm{gal} / \mathrm{min}$ tests.

The change in specific capacity with time for each test is shown in figure 9B. The specific-capacity plots for all tests completed for this study during 2008-09 were nearly identical, indicating that pumping rate did not affect specific capacity; specific capacity of the test completed in April 1980 was notably less. 

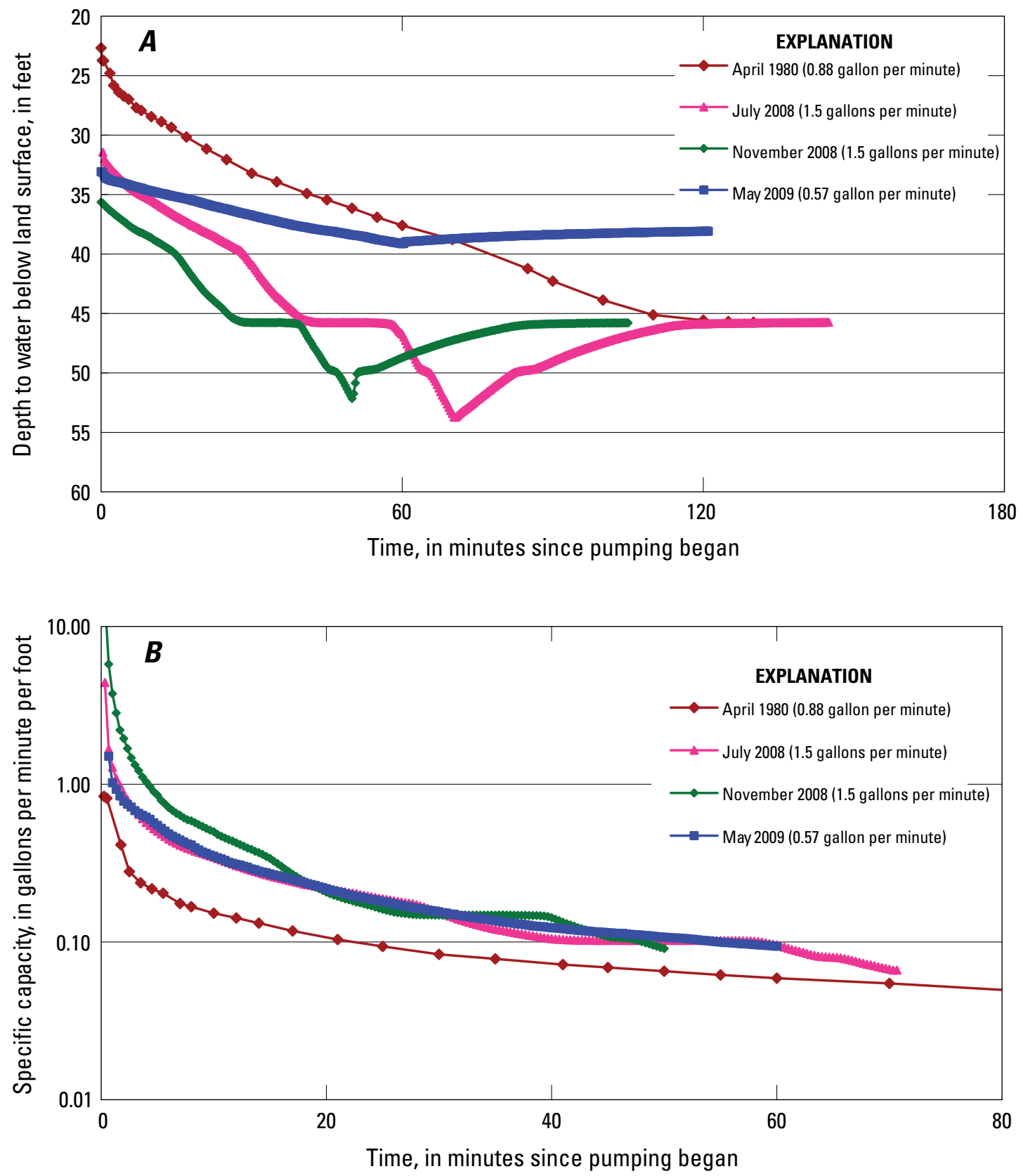

Figure 9. Water level $(A)$ and specific capacity $(B)$ during five specific-capacity tests at well GR 541 in Greene County, Pennsylvania. 


\section{Well WS 155}

Well WS 155 in Washington County is an observation well, maintained and operated by USGS for monitoring drought conditions. The well is completed in sandstone, siltstone, limestone, and shale of the Washington Formation to a depth of $133 \mathrm{ft}$ and cased with 6-in. diameter steel casing to $19 \mathrm{ft}$ below land surface (table 1). The driller reported water entering the well at $2 \mathrm{gal} / \mathrm{min}$ at a depth of $45 \mathrm{ft}$ below land surface (table 1). Geophysical logging indicated openings at about 67, 80, 100, and $116 \mathrm{ft}$ below land surface (fig. 4), and flowmeter surveys indicated that all the water is yielded from depths shallower than $48 \mathrm{ft}$ below land surface. The water is contributed from sandstone according to the description of cuttings from the well. Limestone beds from 30-35, 65-75, 93-105, 148-150, and 155-160 ft below land surface were not reported as water-yielding zones by the driller. The static water level in the well ranged from about 35-38 ft below land surface (fig. 3), which allowed about $92 \mathrm{ft}$ of drawdown available for testing.

Well WS 155 was pumped on three occasions by USGS during 2008-09 (table 2). The well was pumped at $2.5 \mathrm{gal} / \mathrm{min}$ for 180 minutes in March and July 2008, and then allowed to recover for 120 minutes. The well was pumped at $1.0 \mathrm{gal} / \mathrm{min}$ in May 2009, allowed to recover for 40 minutes, and pumped

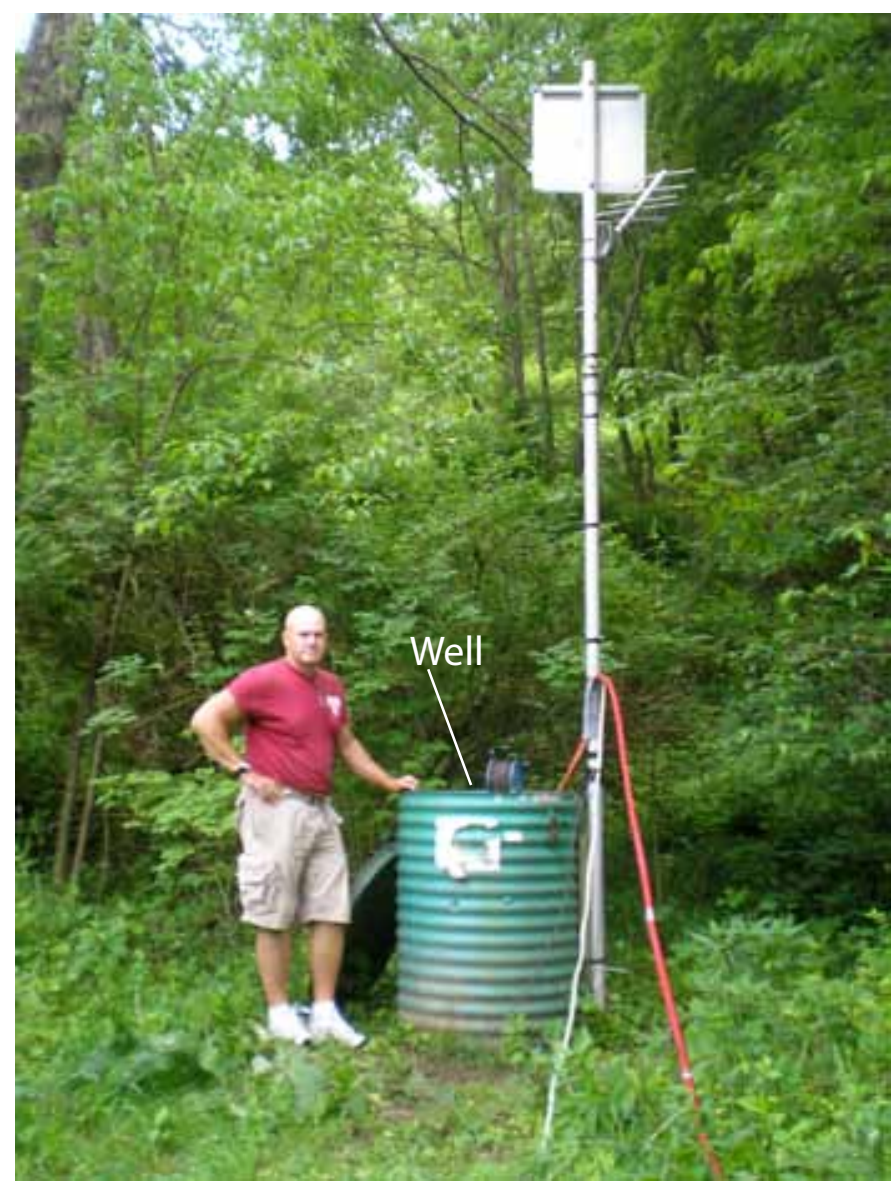

again at $6.0 \mathrm{gal} / \mathrm{min}$ for 35 minutes. A test also was completed by USGS in 1971 for 90 minutes at $2.0 \mathrm{gal} / \mathrm{min}$. Although only drawdown values were reported from that test, the data are plotted on figure 10A assuming that the change in slope of the water-level decline is at a depth of $45 \mathrm{ft}$.

Drawdown and recovery for the five tests are shown in figure 10A. The early-time drawdown data for all tests show the rate of water-level decline decreasing with time, as is characteristic for radial flow to a well. However, in latetime drawdown (greater than 120 minutes) and early-time recovery when the water level was below about $45 \mathrm{ft}$ below land surface, the data plot as straight lines on arithmetic axes. The straight lines indicate that the water-level change is proportional to time, and that the pumped water is being derived from water stored in the well and contributed from the aquifer at a constant rate, independent of drawdown. The drawdown curves plot as straight lines when the water level is greater than $45 \mathrm{ft}$ below land surface, which is the depth of the only water-yielding zone reported by the driller. When the water level is below $45 \mathrm{ft}$, water cascades into the well from the fracture at that depth at a rate independent on the water level in the well. The straight-line drawdown segment starting after about 140 minutes indicates that the rate of withdrawal from wellbore storage was about $0.3 \mathrm{gal} / \mathrm{min}$ for the $2.5 \mathrm{gal} / \mathrm{min}$ test in March 2008 (assuming a 6-in. diameter well) during pumping; the recovery curve indicates a constant inflow of about $2.4 \mathrm{gal} / \mathrm{min}$ after pumping stopped. Thus, the straight-line curves for the March $2.5 \mathrm{gal} / \mathrm{min}$ test indicate a constant inflow of about 2.2 to $2.4 \mathrm{gal} / \mathrm{min}$, which is a reasonable estimate of the maximum well yield. The slope of the straight-line recovery curve indicated a constant inflow of $3.0 \mathrm{gal} / \mathrm{min}$ for the $6 \mathrm{gal} / \mathrm{min}$ test. Thus, the yield of the well is probably about $2-3 \mathrm{gal} / \mathrm{min}$. Data from the $1 \mathrm{gal} / \mathrm{min}$ test in May 2009 did not show any straight-line segment of waterlevel change as observed in the other tests because the water level did not fall below the major water-yielding zone at $45 \mathrm{ft}$ below land surface.

The change in specific capacity with time for each of the five tests is shown in figure 10B. The specific-capacity values for all tests compare closely until the water level drops below $45 \mathrm{ft}$ below land surface. At that point, the rate of change for specific capacity with time increases because the rate of change in drawdown has changed (fig. 10A). Therefore, specific capacity is not dependent on pumping rate for tests completed when the water level is less than $45 \mathrm{ft}$ below land surface. The pumping rate affects specific capacity, but not because of head losses caused by turbulent flow. Instead, the key factor is the depth of the major water-yielding zone with respect to the water level in the well. 

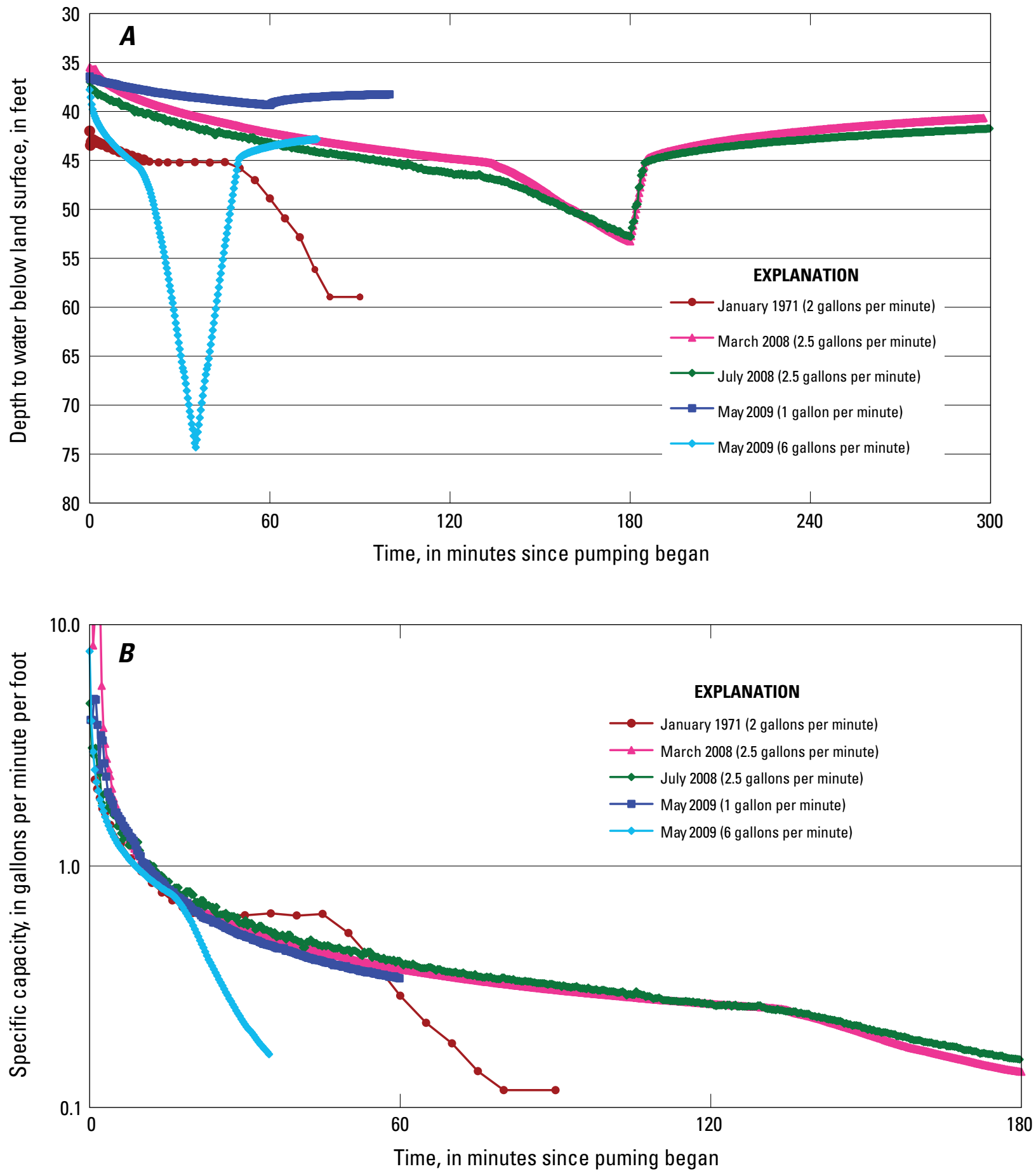

Figure 10. Water level $(A)$ and specific capacity $(B)$ during five specific-capacity tests at well WS 155 in Washington County, Pennsylvania. 


\section{Well YO 1222}

Well YO 1222 in York County is an unused well at the USGS Pennsylvania Water-Science Center office. The well is completed in limestone of the Epler Formation to a depth of $202 \mathrm{ft}$ and is cased with 6.25 -in. diameter steel casing to $18 \mathrm{ft}$ below land surface. The driller reported a water-yielding zone of unspecified rate at $120 \mathrm{ft}$ below land surface and $1 \mathrm{gal} / \mathrm{min}$ at 162 and $2 \mathrm{gal} / \mathrm{min}$ at $168 \mathrm{ft}$ below land surface (table 1). Drill cuttings were described as gray massive limestone throughout, with calcite veins. Geophysical logging indicated few obvious fractures except those fractures at about $27 \mathrm{ft}$ below land surface (fig. 4), which also could be seen on the video log of the well (fig. 5). The static water level in the well ranged from about 18 to $35 \mathrm{ft}$ below land surface (fig. 3), which allowed at least $167 \mathrm{ft}$ of drawdown available for testing.

Well YO 1222 was pumped on six occasions by USGS during 2007-09 (table 2). The well was pumped at about $2 \mathrm{gal} / \mathrm{min}$ in August 2007, July 2008, and August 2008; at 5-6 gal/min in August 2007 and March 2008; and at $14 \mathrm{gal} / \mathrm{min}$ in September 2009. The test in August 2008 was a step-drawdown test in which the well was pumped in four 60-minute steps at increasing rates of 2, 3, 4, and $5 \mathrm{gal} / \mathrm{min}$. Recovery was measured for 60 to 120 minutes for all tests except for the $2 \mathrm{gal} / \mathrm{min}$ test in August 2007, because of equipment problems.

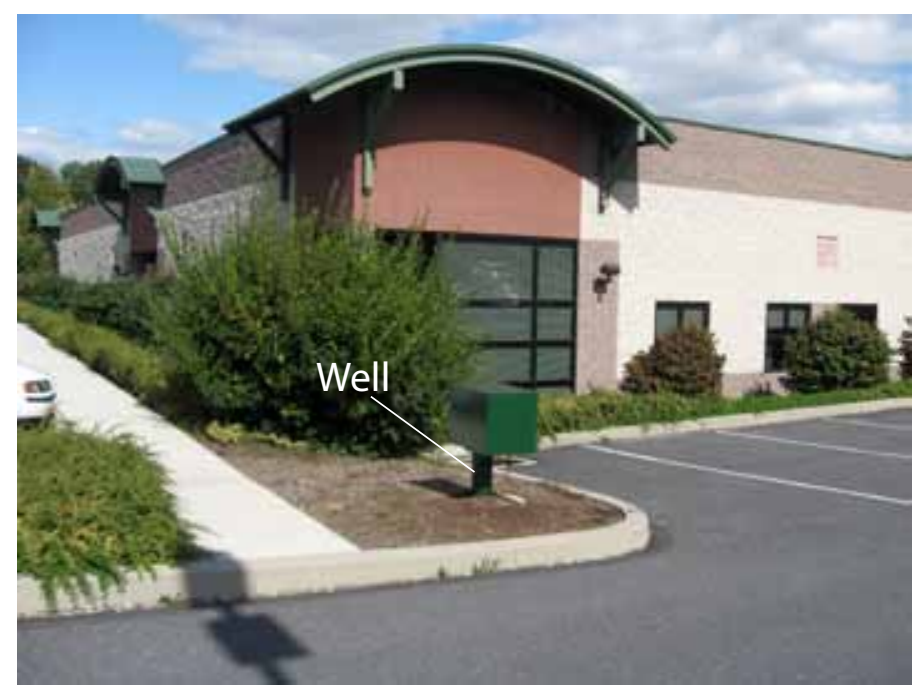

Well YO 1222.
Drawdown and recovery of water levels for the six tests are shown in figure 11A. The water-level drawdown data for all tests show the rate of water-level decline decreasing with time, as is characteristic for radial flow to a well. However, drawdown was slight during the 5-6 gal/min tests. The drawdown for specific-capacity tests completed at 5 or $6 \mathrm{gal} / \mathrm{min}$ was less than for the tests completed at lesser rates, which seems impossible. The reason for this oddity is that the 5-6 gal/min tests were completed during periods when the water level in the well was above the fractures at $27 \mathrm{ft}$ below land surface, which is a major water-bearing zone, capable of providing substantial water to the well when saturated. When the zone is unsaturated, the well yield is considerably smaller, as indicated by the larger water-level drawdown during the $2 \mathrm{gal} / \mathrm{min}$ tests.

The change in specific capacity with time for each of the six tests is shown in figure 11B. The specific capacity for the tests completed from 5 to $6 \mathrm{gal} / \mathrm{min}$ compares closely and after 60 minutes of pumping indicate a value of about $5(\mathrm{gal} / \mathrm{min}) / \mathrm{ft}$. The other tests show some variability, but after 60 minutes of pumping indicate much smaller specific-capacity values from 0.08 to $0.12(\mathrm{gal} / \mathrm{min}) / \mathrm{ft}$. The specific-capacity values determined at YO 1222 are the most varied among the six wells tested for this study. The major factor affecting the specific capacity is the relation of the water level in the well to the major water-yielding zone at $27 \mathrm{ft}$ below land surface. The specific capacity is about 50 times greater when the water level is above that zone than when the water level is below that zone. 

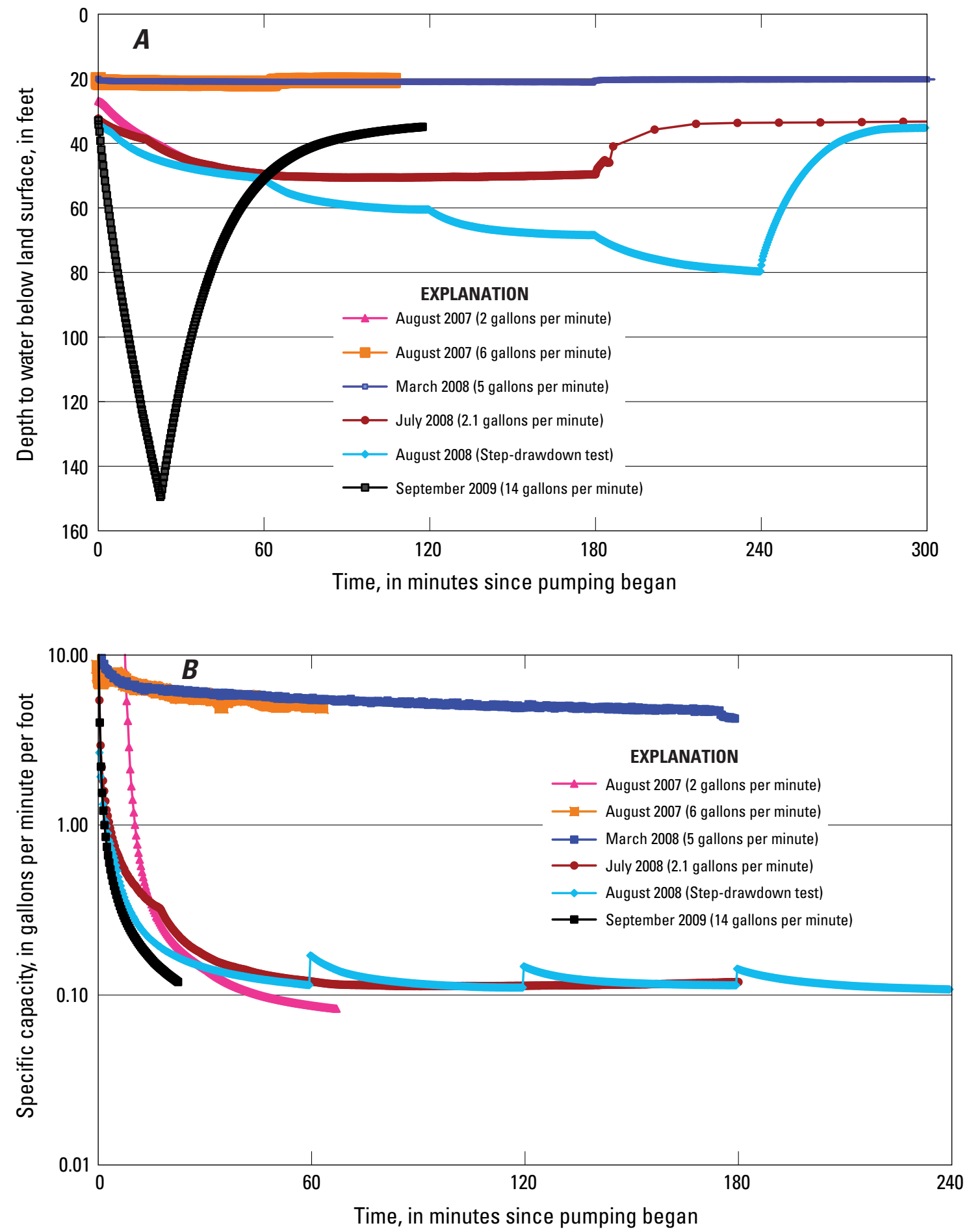

Figure 11. Water level $(A)$ and specific capacity $(B)$ during five specific-capacity tests at well Y0 1222 in York County, Pennsylvania. 


\section{Factors Affecting Specific Capacity}

The factors affecting drawdown in a pumped well have been widely discussed in the literature (Driscoll, 1986; Kruseman and deRidder, 1990). The major factors are pumping duration, pumping rate, wellbore storage, aquifer properties, and turbulent flow influenced by the characteristics of the well screen, casing, and pump. The usefulness of a specificcapacity test is greatly enhanced if the pumping and wellconstruction details have been reported. Individual factors that could affect specific capacity are discussed in this section, by using examples from theoretical simulations and from tests at the six low-yielding wells. The theoretical analysis provides insights into the factors for a simple aquifer (fig. 12) for which each factor can be specified; whereas, the six well tests illustrate the additional complexities caused by the less than ideal fractured-bedrock aquifer and errors inherent in measuring real pumping rates and water levels.

The theoretical analysis of a hypothetical well in an idealized aquifer was made with the use of Aqtesolv, a computer program designed to solve analytical equations for drawdown in wells with different well-construction and aquifer characteristics (Duffield, 2007). The Papadopulos and Cooper (1967) analytical solution in Aqtesolv was used to simulate a uniform, laterally extensive, homogeneous, isotropic aquifer and a finite-diameter well with wellbore storage. A standard case was simulated for a 6-in. diameter well in an aquifer with transmissivity of $T=10 \mathrm{ft}^{2} / \mathrm{d}$ and storage coefficient of $S=0.0001$. Sensitivity of specific capacity was tested for variations in the following properties: pumping rate, pumping duration, and well diameter.

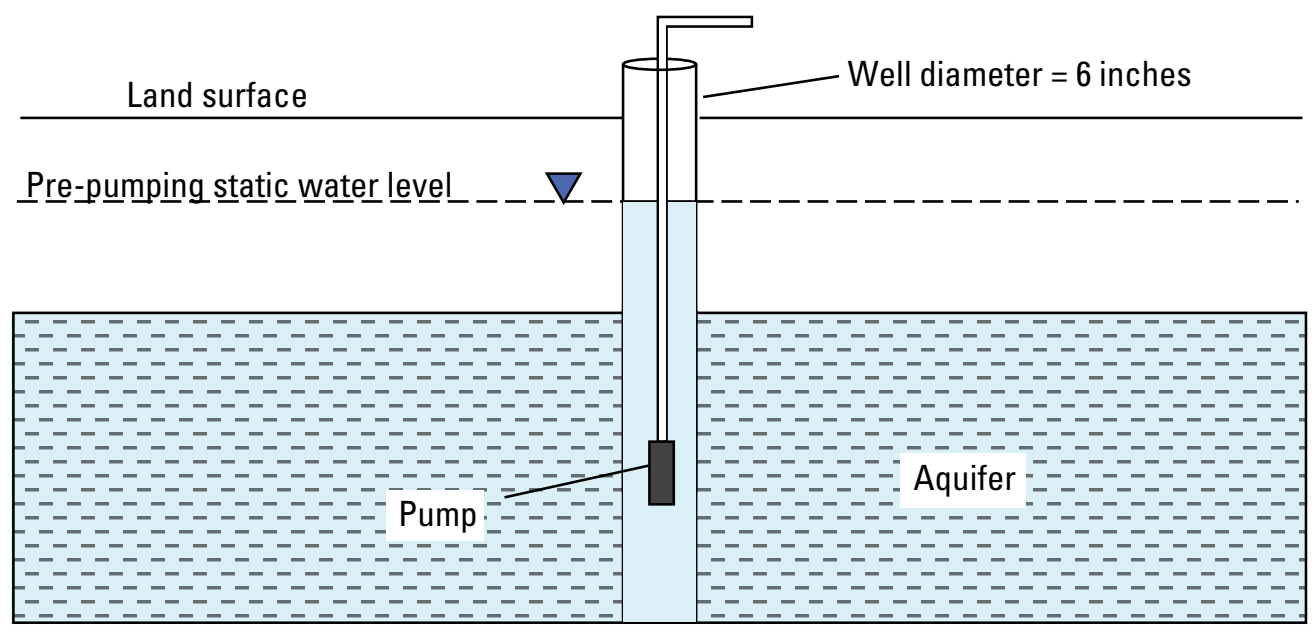

Figure 12. Schematic diagram of a hypothetical well in an idealized homogeneous aquifer used in the theoretical analysis of some factors affecting specific capacity. 


\section{Pumping Duration}

Specific capacity decreases as the duration of pumping increases because drawdown increases with time in the pumped well as shown in equation 3. For this reason, the duration of the test is always noted when reporting a specificcapacity value.

\section{Theory Shows Importance of Pumping Duration Decreases With Time}

The increase in drawdown and decrease in specific capacity with time is shown in figure 13 for pumping of a hypothetical 6 -in. diameter well at $2 \mathrm{gal} / \mathrm{min}$ in an idealized aquifer with transmissivity of $10 \mathrm{ft}^{2} / \mathrm{d}$ and storage coefficient of 0.0001 . The example shows that the rate of change of drawdown and specific capacity decreases with time, so specific-capacity values determined from tests of long duration, in general, are less likely to be affected by differences in test duration than are values derived from short-duration tests. For example, from the data in figure 13, compare the differences in specific capacity between two tests, one having a pumping duration twice as long as the other. For short-duration tests of 30 and 60 minutes, figure 13 shows the specific capacity is $0.088(\mathrm{gal} / \mathrm{min}) / \mathrm{ft}$ after 30 minutes of pumping and $0.065(\mathrm{gal} / \mathrm{min}) / \mathrm{ft}$ after 60 minutes of pumping - a decrease of 26 percent for the test with longer duration. For two tests of longer duration, figure 13 shows that specific capacity is $0.050(\mathrm{gal} / \mathrm{min}) / \mathrm{ft}$ after 240 minutes of pumping and 0.047 (gal $/ \mathrm{min}) / \mathrm{ft}$ after 480 minutes of pumping — a decrease of only about 6 percent.

Drawdown will increase and specific capacity will decrease until the well reaches equilibrium. Equilibrium is only reached when the drawdown in the aquifer caused by the pumping decreases the natural discharge of the aquifer and (or) increases the natural recharge in an amount equal to the pumping rate. Equilibrium cannot be reached in the theoretical example because the only source of water is storage in the aquifer, and in reality, equilibrium usually is not achieved in short-term tests of low-yielding aquifers. However, as shown by the hypothetical example in figure 13, the rate of change of water-level drawdown decreases with time until an apparent equilibrium condition can be reached in which drawdown and specific capacity change only slightly with time.
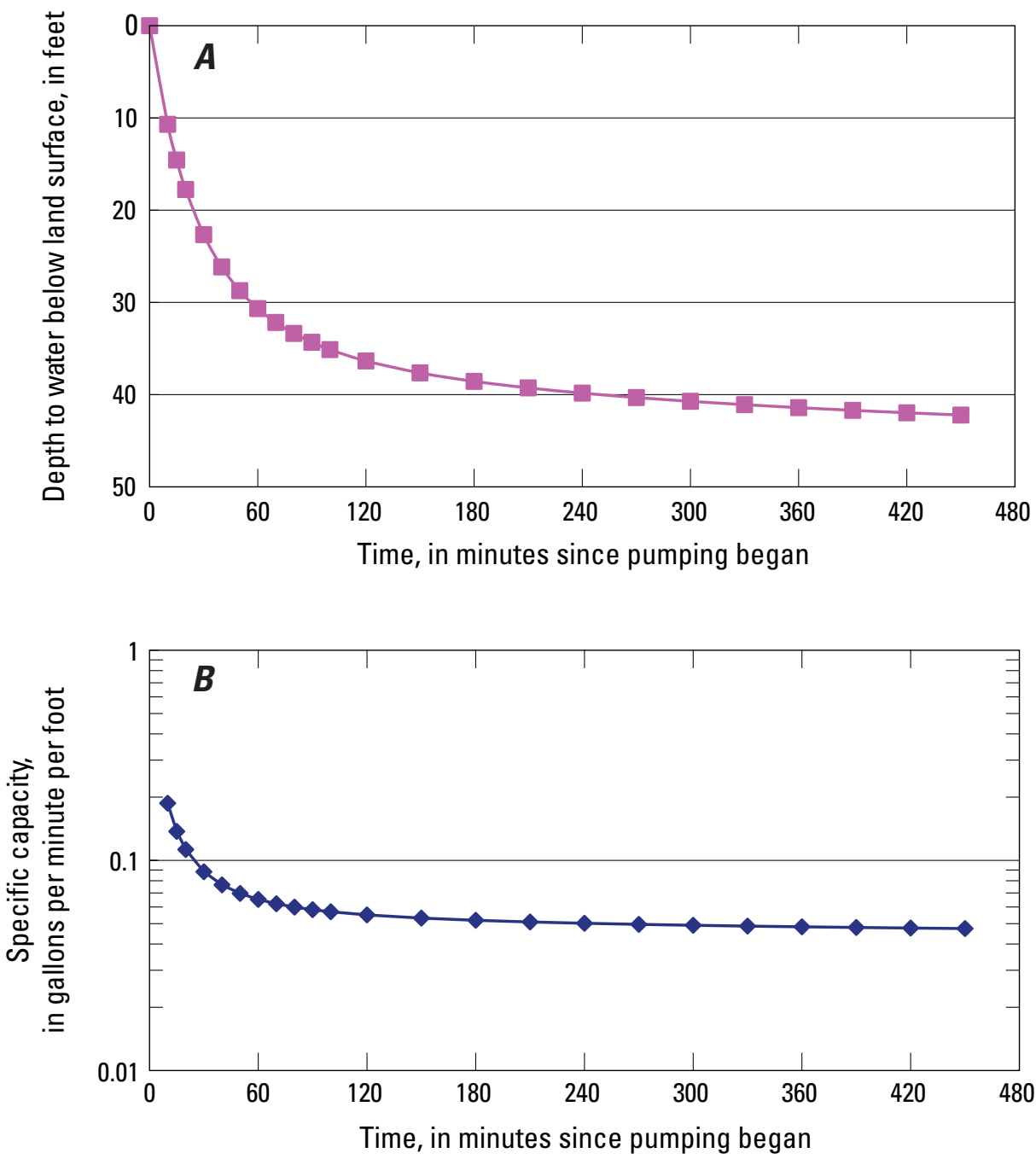

Figure 13. Change in drawdown and specific capacity with duration of pumping for constant withdrawal of 2 gallons per minute from a hypothetical 6-inch diameter well in an idealized aquifer with transmissivity 10 feet squared per day and storage coefficient of 0.0001 . 


\section{Tests Show Effect of Pumping Duration on Specific Capacity}

Results from all the tests were consistent with the theory that pumping duration is an influential factor controlling specific capacity. At least one test was completed at each of the 6 test wells for 180 minutes or until the water level in the well declined to the depth of the transducer setting to evaluate the effect of pumping duration on specific capacity. Examples of pumping-test data from each of the 6 wells showed an increase in drawdown (fig. 14A) and decrease in specific capacity (fig. 14B) with time. Specific-capacity values declined quickly in the early part of all tests, illustrating the value of pumping for durations longer than 60 minutes. Specific-capacity values after 180 minutes of pumping decreased from 0 to 62 percent compared to the value after 60 minutes for the four wells that were pumped for the full 180 minutes (table 3). Comparisons for wells AR 110 and GR 541 are not shown in table 3 because the water levels reached the transducer setting near the bottom of the wells; therefore, those tests were terminated prior to 180 minutes.
Drawdown increased with time in well BV 156, but at a decreasing rate, similar to the response to pumping at the hypothetical well (fig. 13). The specific capacity, in well CA 462, was more affected by duration of pumping when pumped at $2 \mathrm{gal} / \mathrm{min}$ than at $1 \mathrm{gal} / \mathrm{min}$. Specific capacity decreased less than 20 percent between 60 and 180 minutes of pumping at the lower pumping rate, but at the higher rate, the decrease was about 60 percent (table 3). In well WS 155, at about 130 minutes, the rate of drawdown unexpectedly increased, which resulted in an increase in the rate of decline of specific capacity. The drawdown declined little after 60 minutes of pumping in YO 1222, and stabilized at 80 minutes, indicating an apparent equilibrium condition had been reached, which resulted in a steady specific-capacity value of about $0.12(\mathrm{gal} / \mathrm{min}) / \mathrm{ft}$ (fig. 14 and table 2). Thus, for well YO 1222, after about 60 minutes, duration of pumping was not a factor affecting specific capacity. Drawdown at the end of the tests in wells AR 110, CA 462, GR 541, and WS 155 were proportional to time (linear), indicating that most of the pumped water was being derived from wellbore storage or was cascading into the well at a rate independent of the water level in the well.

Table 3. Comparison of specific-capacity values after 60 and 180 minutes of pumping.

[gal/min, gallons per minute; (gal/min)/ft, gallons per minute per foot]

\begin{tabular}{|c|c|c|c|c|c|}
\hline \multirow{2}{*}{ Well' } & \multirow{2}{*}{$\begin{array}{c}\text { Pumping rate } \\
\text { (gal/min) }\end{array}$} & \multicolumn{3}{|c|}{$\begin{array}{c}\text { Specific capacity } \\
{[(\text { gal } / \mathrm{min}) / \mathrm{tt}]}\end{array}$} & \multirow{2}{*}{$\begin{array}{c}\text { Percent } \\
\text { difference }^{2}\end{array}$} \\
\hline & & $\begin{array}{l}\text { After } 60 \text { minutes } \\
\text { pumping }\end{array}$ & $\begin{array}{l}\text { After } 180 \text { minutes } \\
\text { pumping }\end{array}$ & Difference & \\
\hline BV 156 & 5.0 & 0.17 & 0.11 & -0.06 & -35 \\
\hline BV 156 & 5.0 & .19 & .13 & -.06 & -32 \\
\hline CA 462 & 2.0 & .047 & .019 & -.028 & -60 \\
\hline CA 462 & 2.0 & .058 & .022 & -.036 & -62 \\
\hline CA 462 & 1.0 & .12 & .10 & -.02 & -17 \\
\hline CA 462 & 1.0 & .15 & .14 & -.01 & -6.7 \\
\hline WS 155 & 2.5 & .37 & .14 & -.23 & -62 \\
\hline WS 155 & 2.5 & .41 & .16 & -.25 & -61 \\
\hline YO 1222 & 5.0 & 5.5 & 4.20 & -1.3 & -24 \\
\hline YO 1222 & 2.1 & .12 & .12 & 0 & 0 \\
\hline YO 1222 & 2.0 & .11 & .11 & 0 & 0 \\
\hline
\end{tabular}

${ }^{1} \mathrm{AR} 110$ and GR 541 are not included because the wells were not pumped for 180 minutes during any of the tests.

${ }^{2}$ Ratio of the difference divided by the specific capacity after 60 minutes of pumping, as percent. 

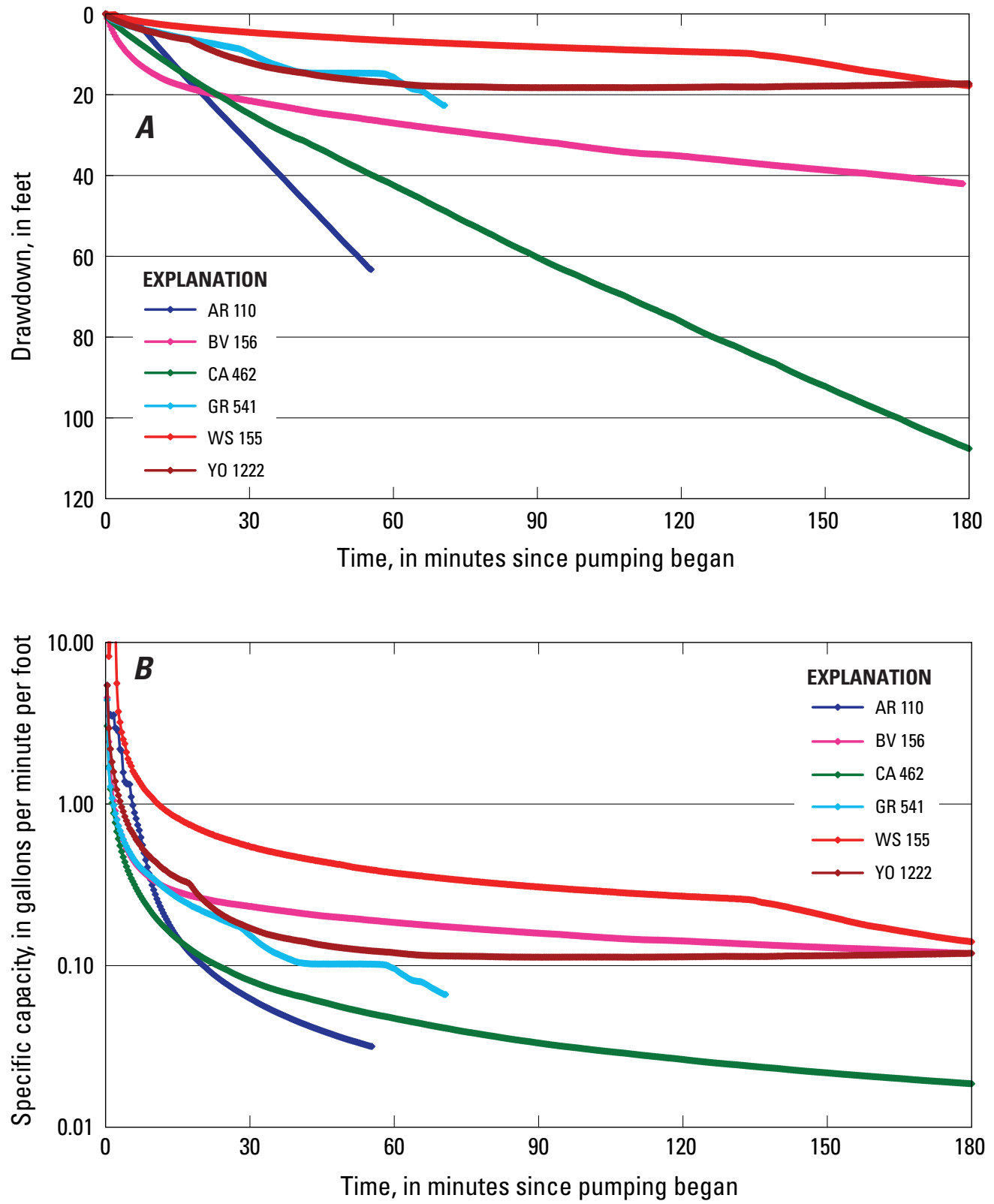

Figure 14. Drawdown $(A)$ and specific capacity $(B)$ with time during selected specific-capacity tests at six low-yielding wells in fractured-bedrock aquifers in Pennsylvania. 


\section{Pumping Rate}

Specific capacity may be affected by pumping rate under some conditions, so the pumping rate is always reported. Generally, when comparing tests, a good practice is to repeat tests at the same pumping rate, but some tests completed at different pumping rates may be comparable.

\section{Theory Shows Pumping Rate May Not Affect Specific Capacity}

The general equation for drawdown in the pumped well (eq. 3) shows that drawdown is directly proportional to the pumping rate provided that the turbulent-flow factor (eq. 4) is small and the factors inherent in coefficient $B$ (time, well radius, transmissivity, and storage coefficient) are constant. Specific capacity, in theory, will not depend on the pumping rate if all flow in the aquifer and well is laminar.

Drawdown simulated after 180 minutes of pumping from the 6-in. diameter hypothetical well at rates from $2-10 \mathrm{gal} / \mathrm{min}$ is shown for the well with and without turbulent flow (fig. 15). The plot shows that specific capacity remains a constant value of $0.052(\mathrm{gal} / \mathrm{min}) / \mathrm{ft}$ regardless of the pumping rate for a well with no turbulent flow. However, when turbulent flow is simulated, the drawdown is proportionally greater at higher pumping rates, which decreases specific capacity. Turbulent flow is not usually a major factor contributing to drawdown for wells pumped at low rates $(2-10 \mathrm{gal} / \mathrm{min})$. The turbulent-flow factor $C$ (eq. 4) used to produce the plot in figure 15 was much larger than would be typical, therefore, the effect of turbulence for these low pumping rates is exaggerated.

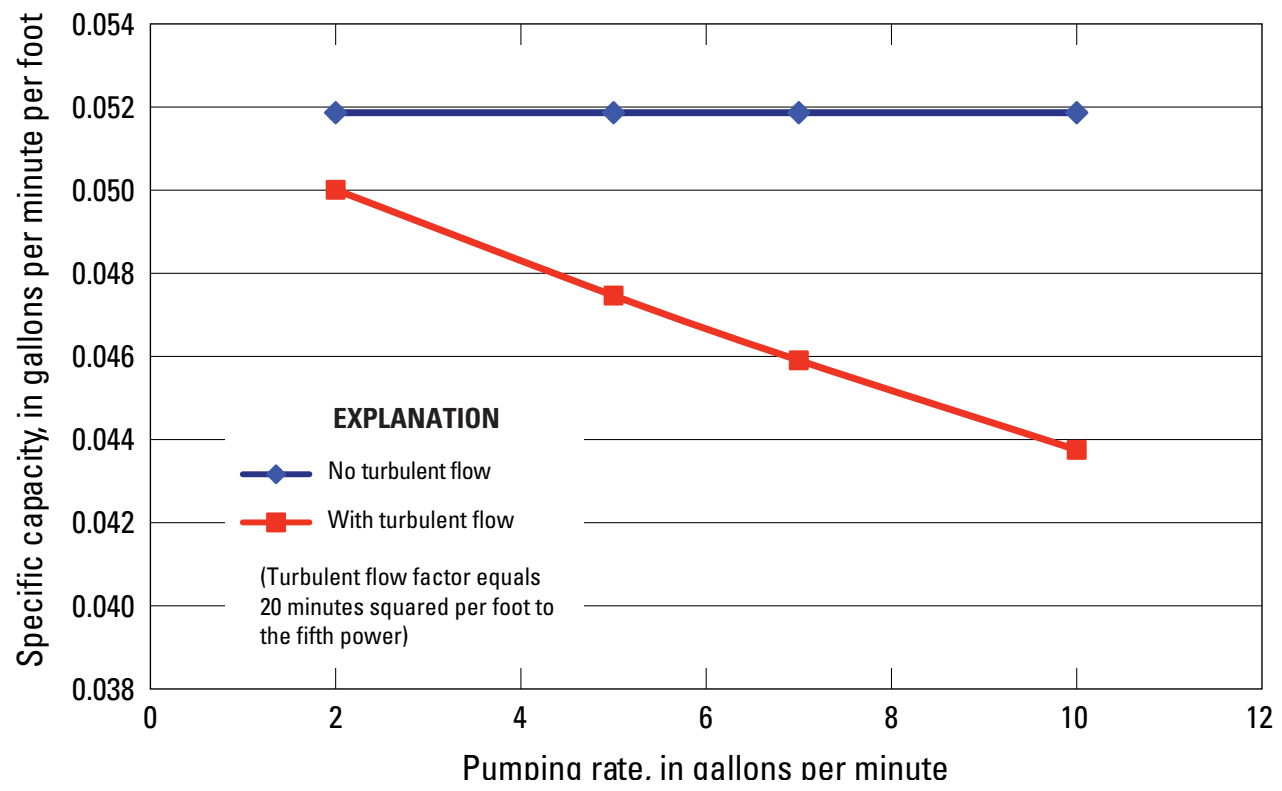

Figure 15. Theoretical specific capacity with and without turbulent flow for pumping at rates from 2 to 10 gallons per minute for 180 minutes in a hypothetical 6 -inch diameter well with wellbore storage. 


\section{Essential to Know Pumping Rate and Hold Discharge Steady}

According to the definition of specific capacity (eq. 1), any error in measuring the pumping rate $Q$ translates directly to an error in the specific capacity $S C$; thus, pumping rate needs to be measured accurately during a test. For example, if the measured pumping rate was $4 \mathrm{gal} / \mathrm{min}$ and the actual rate was $5 \mathrm{gal} / \mathrm{min}$, the 20 percent error in determination of the pumping rate would cause a 20 percent error in the computed specific capacity. Thus, a good practice would be to check the discharge rate from a pump by more than one method. If a flowmeter is used to measure discharge, readings can be checked against a volumetric measurement with a watch and a graduated or known-volume container.

The largest source of experimental error in computing specific capacity is usually from the measurement of the pumping rate because manual adjustments to a valve on the discharge pipe are typically needed to hold the rate constant as drawdown in the well increases. The precision of the pumping rates in this study were within about $1-5$ percent of the mean value. An example of the variability in discharge rate is shown on the graph of discharge from the test at WS 155 in July 2008 (fig. 16). The accuracy of the measurements was not assessed other than to note that the flowmeter readings corresponded to periodic volumetric measurements within about 5 percent, and that comparison readings from two different flowmeters on the same discharge line sometimes differed by as much as 5 percent.

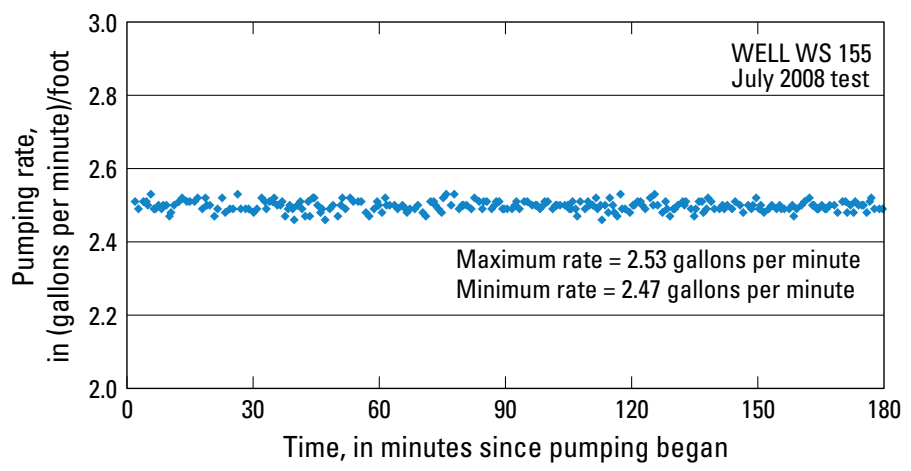

Figure 16. Variability of the pumping rate during the 2.5 gallonper-minute specific-capacity test at well WS 155 in July 2008.
Results from a specific-capacity test can be more accurately compared to subsequent tests if the pumping rate is held constant through the duration of the test. The effects of varied pumping rate are illustrated with results from two simulated tests at the hypothetical well (fig. 17). The pumping rate was held steady at $5 \mathrm{gal} / \mathrm{min}$ in one test, which resulted in a drawdown of $96 \mathrm{ft}$ after 180 minutes of pumping and a specific capacity of $0.052(\mathrm{gal} / \mathrm{min}) / \mathrm{ft}$. The pumping rate was $6 \mathrm{gal} / \mathrm{min}$ during the first 90 minutes and $4 \mathrm{gal} / \mathrm{min}$ during the final 90 minutes in the other test, resulting in, after 180 minutes of pumping, a drawdown of $81 \mathrm{ft}$ and specific capacity of 0.062 $(\mathrm{gal} / \mathrm{min}) / \mathrm{ft}$ if the average pumping rate of $5 \mathrm{gal} / \mathrm{min}$ is used to compute specific capacity.

The total quantity of water withdrawn (900 gal) and average pumping rate $(5 \mathrm{gal} / \mathrm{min})$ were the same for both tests, but use of the average pumping rate to compute specific capacity did not produce the same result for both tests. Thus, a good practice would be to document variations in pumping rate throughout the duration of the test instead of relying solely on a computation of the average pumping rate determined from the total volume pumped during the test divided by the duration of pumping. In fact, in this example, the drawdown at the end of the test has nearly adjusted to the pumping rate of $4 \mathrm{gal} / \mathrm{min}$; thus, a better estimate of the specific capacity would be obtained by dividing the drawdown of $81 \mathrm{ft}$ into $4 \mathrm{gal} / \mathrm{min}$ to yield 0.049 (gal $/ \mathrm{min}) / \mathrm{ft}$. Commonly, the pumping rate will decline slowly during a test as the water level in the well falls, causing the drawdown to stabilize temporarily and leading to the false conclusion that equilibrium has been achieved.

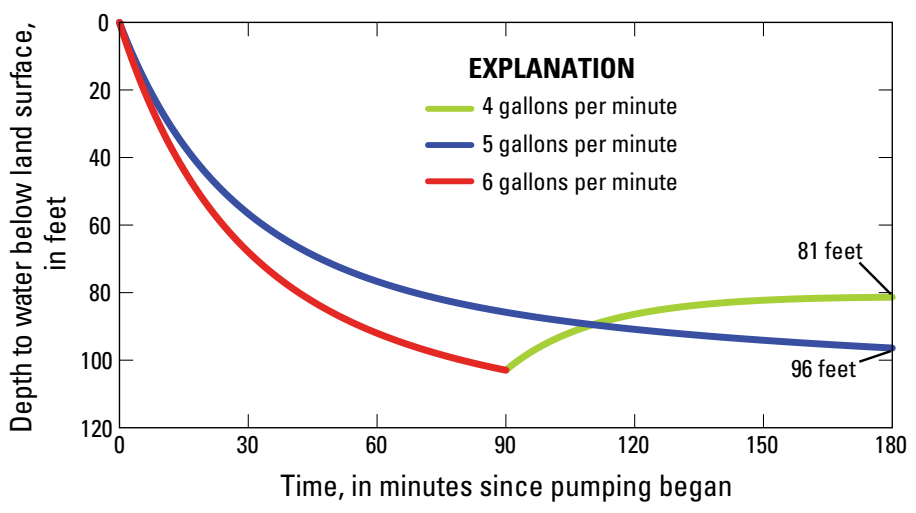

Figure 17. Theoretical drawdown for constant-rate pumping at 5 gallons per minute and varied-rate pumping at 6 gallons per minute for 90 minutes followed by 4 gallons per minute for 90 minutes at the hypothetical well. 


\section{Tests Show Differing Effects of Pumping Rate on Specific Capacity}

Specific-capacity values from multiple tests are compared for the same duration of pumping (60 minutes for most wells) in figure 18. Values from tests completed at the same (or nearly same) pumping rate all differed by less than 36 percent, and generally agreed within about 20 percent (table 4 ). When tested at greater rates, specific-capacity values compared closely at wells AR 110, GR 541, and WS 155, decreased substantially at wells BV 156 and CA 462, and increased by a factor of about 50 at well YO 1222 (table 5). Details about the change in specific capacity with time during each test are illustrated in figures 6B-11B.

Specific-capacity values after 49 minutes of pumping for two tests completed at $2 \mathrm{gal} / \mathrm{min}$ and one test at $0.88 \mathrm{gal} / \mathrm{min}$ for well AR 110 compare within about 9 percent of the mean value (table 4 and fig. 18), showing that results from tests completed at the same rate and duration are reproducible to that extent and that differing pumping rates did not affect specific capacity. The specific-capacity value from the historical test completed in 1999 at $3.5 \mathrm{gal} / \mathrm{min}$ was substantially greater than for tests completed during 2008-09. The smaller specificcapacity values from the more recent tests may be the result of clogging of water-yielding fractures over time.

Specific-capacity values for well BV 156 after 60 minutes of pumping for two tests completed at $5 \mathrm{gal} / \mathrm{min}$ compare within 11 percent of the mean value (table 4 and fig. 18), showing that tests completed at the same rate and duration are reproducible to that extent. The substantially larger specificcapacity value for the $2.5 \mathrm{gal} / \mathrm{min}$ test and smaller value for the $7.9 \mathrm{gal} / \mathrm{min}$ test indicate that pumping rate does substantially affect specific capacity. The effect could be caused by turbulent head losses but is more likely caused by dewatering of shallow water-yielding fractures (causing a decrease in transmissivity) as the pumping rate is increased.

Specific capacity for well CA 462 after 60 minutes of pumping compares reasonably well (about 20 percent of the mean value) for tests completed at the same rate (either 1 or $2 \mathrm{gal} / \mathrm{min}$ ) (table 4 and fig. 18), showing that tests completed at the same rate and duration are reproducible to that extent. The subsequent test had the greater specific capacity for the tests repeated at the same rate, which may indicate a slight development of the well during each successive test. The decrease in specific-capacity values for tests completed at increasing rates from 1.0 to $4.5 \mathrm{gal} / \mathrm{min}$ indicates that pumping rate does substantially affect specific capacity. The higher pumping rates caused dewatering of the water-yielding zone from $20-50 \mathrm{ft}$ below land surface, causing a decrease in transmissivity.

Specific capacity for well GR 541 after 50 minutes of pumping compares within about 9 percent of the mean value for the two tests completed at $1.5 \mathrm{gal} / \mathrm{min}$ (table 4 and fig. 18), showing that tests completed at the same rate and duration are reproducible to that extent. Specific capacity was only 13 percent smaller for the tests completed at $1.5 \mathrm{gal} / \mathrm{min}$ than for a test completed at $0.57 \mathrm{gal} / \mathrm{min}$ (table 5), showing that pumping rate does not have much effect on specific capacity. The smaller specific-capacity value for the historical test completed in 1980 may indicate the well/aquifer connection has changed.

Specific-capacity values for well WS 155 after 60 minutes of pumping for two tests completed at $2.5 \mathrm{gal} / \mathrm{min}$ compare within 10 percent of the mean value, showing that tests completed at the same rate and duration are reproducible to that extent (table 4 and fig. 18). The specific-capacity value for the $2.5 \mathrm{gal} / \mathrm{min}$ test is 15 percent larger than for the $1.0 \mathrm{gal} / \mathrm{min}$ tests, indicating that pumping rate does not greatly affect specific capacity at these rates. How a lesser pumping rate could result in the smaller specific-capacity value is difficult to understand, so other factors such as measurement error may be involved.

Specific-capacity values for well YO 1222 are similar for tests conducted at similar rates (fig. 18 and table 4) but greatly different for tests completed at different pumping rates (fig. 18 and table 5). Specific-capacity values after $60 \mathrm{~min}-$ utes of pumping for two tests completed at 5 and $6 \mathrm{gal} / \mathrm{min}$ compare within 8 percent of the mean value and three tests completed at 2.0-2.1 gal/min compare within 36 percent of the mean value (table 4), showing that tests completed at the same rate and duration can be reproduced to that degree. However, the specific-capacity values for the 5 to $6 \mathrm{gal} / \mathrm{min}$ tests are about 60 times greater than those values for tests completed at $2 \mathrm{gal} / \mathrm{min}$ (table 5). This difference seems to be caused by differences in pumping rate, but rate is not the major control. The large specific-capacity values are seen when the well is pumped during periods when the water level in the well is above the major water-yielding fractures at $27 \mathrm{ft}$ below land surface, which greatly increase the aquifer transmissivity. 
Table 4. Specific-capacity values from two or three tests completed at the same pumping rate at each of six low-yielding wells in fractured-bedrock aquifers in Pennsylvania.

[gal/min, gallons per minute; min, minutes; (gal/min)/ft, gallons per minute per foot; --, no data]

\begin{tabular}{|c|c|c|c|c|c|c|c|c|}
\hline \multirow{2}{*}{ Well } & \multirow{2}{*}{$\begin{array}{l}\text { Pumping rate } \\
\text { (gal/min) }\end{array}$} & \multirow{2}{*}{$\begin{array}{c}\text { Duration of } \\
\text { pumping } \\
\text { (min) }\end{array}$} & \multicolumn{5}{|c|}{$\begin{array}{c}\text { Specific capacity } \\
{[(\mathrm{gal} / \mathrm{min}) / \mathrm{ft}]}\end{array}$} & \multirow{2}{*}{$\begin{array}{c}\text { Maximum } \\
\text { percent } \\
\text { difference }^{1}\end{array}$} \\
\hline & & & Test 1 & Test 2 & Test 3 & $\begin{array}{c}\text { Mean } \\
\text { (rounded) }\end{array}$ & $\begin{array}{l}\text { Maximum } \\
\text { difference }\end{array}$ & \\
\hline AR 110 & 2.0 & 49 & 0.035 & 0.032 & -- & 0.034 & 0.003 & 9 \\
\hline BV 156 & 5.0 & 60 & .17 & .19 & -- & .180 & .020 & 11 \\
\hline CA 462 & 2.0 & 60 & .12 & .15 & -- & .135 & .030 & 22 \\
\hline WS 155 & 2.5 & 60 & .37 & .41 & -- & .390 & .040 & 10 \\
\hline YO 1222 & 2.0 & 60 & .083 & .12 & 0.11 & .104 & .037 & 36 \\
\hline
\end{tabular}

${ }^{1}$ Ratio of maximum difference to the mean value of specific capacity, as percent.

Table 5. Specific-capacity values from tests completed at different pumping rates at six low-yielding wells in fractured-bedrock aquifers in Pennsylvania.

[Underlined values represent the mean specific capacity from two or three tests. min, minutes; gal $/ \mathrm{min}$, gallons per minute; (gal/min)/ft, gallons per minute per foot]

\begin{tabular}{|c|c|c|c|c|c|c|c|}
\hline \multirow{2}{*}{ Well } & \multirow{2}{*}{$\begin{array}{c}\text { Duration of } \\
\text { pumping } \\
\text { (min) }\end{array}$} & \multirow{2}{*}{$\begin{array}{c}\text { Low } \\
\text { pumping rate } \\
\text { (gal/min) }\end{array}$} & \multirow{2}{*}{$\begin{array}{c}\text { High } \\
\text { pumping rate } \\
\text { (gal/min) }\end{array}$} & \multicolumn{3}{|c|}{$\begin{array}{c}\text { Specific capacity } \\
{[(\text { gal } / \text { min }) / f t]}\end{array}$} & \multirow{2}{*}{$\begin{array}{c}\text { Percent } \\
\text { difference }^{1}\end{array}$} \\
\hline & & & & Low rate test & High rate test & Difference & \\
\hline AR 110 & 49 & 0.88 & 2.0 & 0.034 & 0.034 & 0.000 & 0 \\
\hline BV 156 & 60 & 2.50 & 5.0 & .27 & .18 & -.09 & -33 \\
\hline CA 462 & 60 & 1.00 & 2.0 & .14 & .052 & -.088 & -63 \\
\hline GR 541 & 50 & .57 & 1.5 & .11 & .096 & -.014 & -13 \\
\hline WS 155 & 60 & 1.00 & 2.5 & .34 & .39 & .05 & 15 \\
\hline YO 1222 & 60 & 2.00 & 6.0 & .10 & 5.1 & 5.0 & 5,000 \\
\hline
\end{tabular}

${ }^{1}$ Ratio of the difference divided by the specific capacity from the low rate test, as percent.

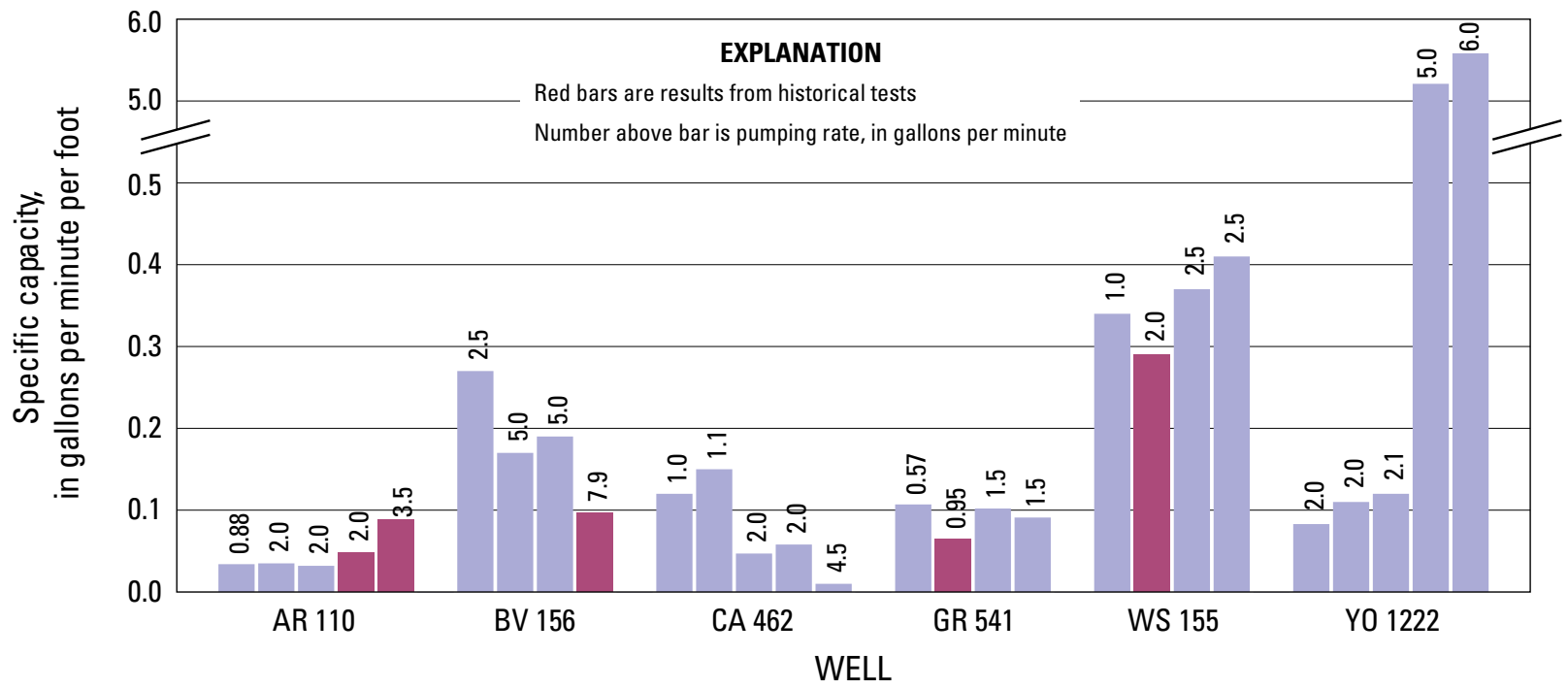

Figure 18. Specific-capacity values for tests completed at different rates after 60 minutes of pumping (49 minutes at AR 110 and 50 minutes at GR 541; estimated values as listed in table 2) at six low-yielding wells in fractured-bedrock aquifers in Pennsylvania. 


\section{Wellbore Storage}

Some water is always removed from the wellbore when a well is pumped. The quantity of water stored in the well may not be a substantial source of water for some water-supply wells, but for low-yielding wells, wellbore storage may provide most of the water withdrawn during the course of a 1- to 3-hour specific-capacity test. Thus, wellbore storage can have a substantial effect on specific capacity.

\section{Theory Shows Importance of Wellbore Storage in Early Time}

The drawdown of short-term specific-capacity tests in low-yielding aquifers is reduced because of water stored in the pumped well. As the duration of pumping increases, the percentage of water contributed from the aquifer usually increases and the effect of the wellbore storage diminishes. The length of time $\left(t_{c}\right)$ during which wellbore storage will have a substantial (more than 5 percent) effect on drawdown of an ideal well was given by Reed (1980, p. 39) from the work of Papadopulos and Cooper (1967) as:

$$
t_{c}>\frac{25 r_{c}^{2}}{T},
$$

where

$t_{c} \quad$ is the critical time, in days; and

$r_{c} \quad$ is the radius of the well casing through which the water level fluctuates, in feet.

Equation 5 shows that the effect of wellbore storage will last longer for wells with large diameter casing and small transmissivity. The pumping rate does not affect the critical time $(t)$ at which wellbore storage becomes negligible.

The effect of wellbore storage on drawdown was simulated for hypothetical wells with diameters of 4, 6, and 8 in., pumping at $5 \mathrm{gal} / \mathrm{min}$ from an idealized aquifer with small transmissivity $\left(10 \mathrm{ft}^{2} / \mathrm{d}\right)$ and storage coefficient of 0.0001 (fig. 19A). Simulated drawdown is smallest in the 8-in. diameter well because the "extra" water from the large wellbore is greatest for that well compared to the 4- and 6-in. diameter wells. The differences in drawdown among the three wells are substantial throughout the 180 minutes of simulated pumping, causing differences in the theoretical specific-capacity values (fig. 19B).

Although the effects of wellbore storage on low-yielding wells may linger throughout the duration of the test, the reproducibility of specific-capacity values between successive tests at the same well should not be affected as long as the well diameter is not changing. For example, figure 15 shows simulations for the hypothetical well of 6-in. diameter, pumped at differing rates. The specific capacity after 1-hour of pumping (with no turbulent flow) shows a constant value of specific capacity of $0.052(\mathrm{gal} / \mathrm{min}) / \mathrm{ft}$ regardless of pumping rate.
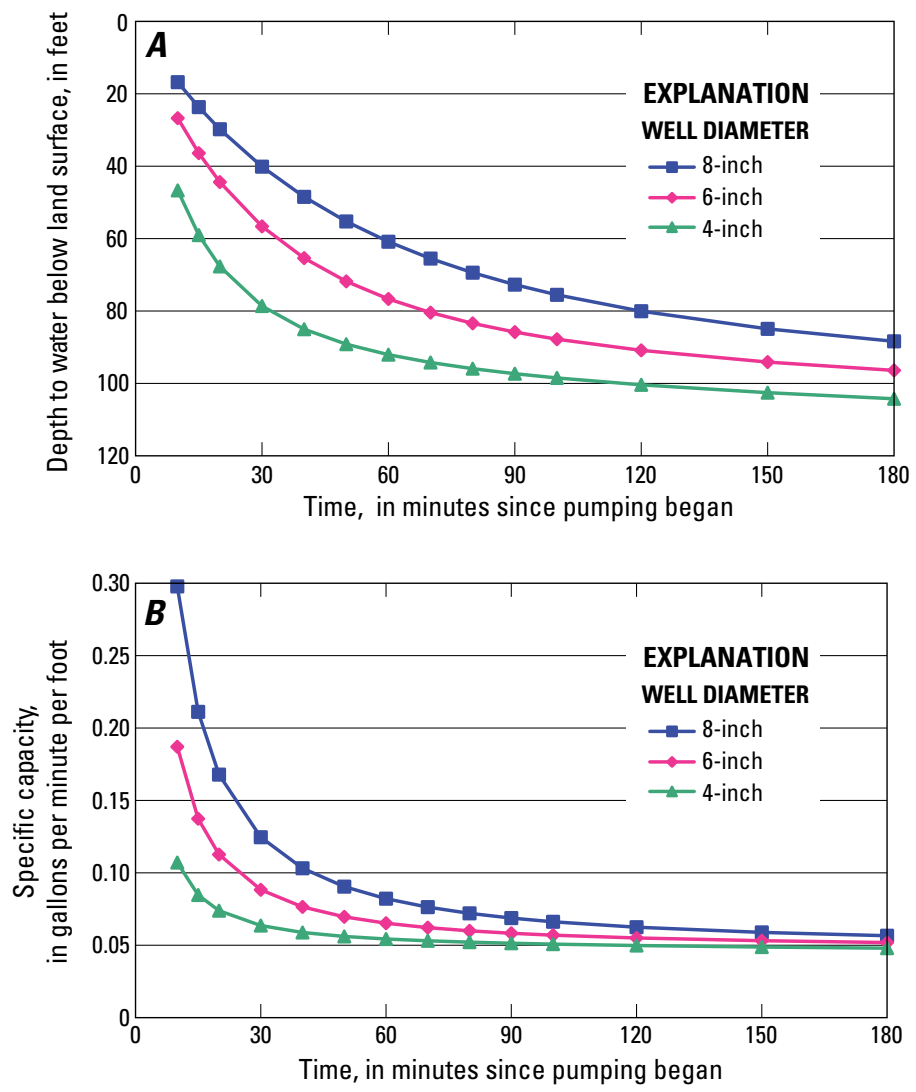

Figure 19. Drawdown $(A)$ and specific capacity $(B)$ for well diameters of 4,6 , and 8 inches simulated with the hypothetical well (pumping rate $=5$ gallons per minute, transmissivity $=10$ feet squared per day, storage coefficient $=0.0001$ ) . 


\section{Wellbore-Storage Correction Can Improve} Estimates of Well Yield

Pennsylvania Department of Environmental Protection (1999) recommends that the pumping rate be adjusted for the volume of water removed from wellbore storage before using specific capacity to compute well yield. The correction is needed because tests of short duration at low-yielding wells may draw only a small fraction of the discharged water from the aquifer. Thus, specific-capacity values determined from these tests might overestimate the ability of the aquifer to provide water to the well.

Well yield is often estimated by multiplying the available drawdown in the well times the specific capacity (Heath, 1983, p. 77). If the specific capacity for an ideal well has been computed from a test where the water level has come close to reaching an apparent equilibrium, that value can be multiplied by the available drawdown to provide an estimate of well yield. If the well has not reached equilibrium, the specific capacity from a short-term test needs to be reduced to compensate for the additional drawdown that would happen during longer pumping periods.

Adjusting a short-duration specific-capacity test to estimate long-term well yield is a challenge (Heath, 1983, p. 58), but for a test where wellbore storage is a substantial source of water, the compensation between early and late-time specificcapacity values needs to be greater than if wellbore storage were not a factor. For example, in figure 19B, the specific capacity for the 8 -in. well after 30 minutes of pumping is 120 percent greater than the value after 180 minutes; whereas, the specific capacity for the 4-in. well (less affected by wellbore storage) is only about 30 percent greater.

The adjustment of specific capacity recommended by Pennsylvania Department of Environmental Protection (1999) removes the volume of water withdrawn from wellbore storage prior to computing specific capacity as shown in equation 6 .

$$
S C(\operatorname{adj})=\frac{\left(V_{p}-V_{b}\right) / t}{s},
$$

where

$S C$ (adj) is the adjusted specific capacity, in gallons per minute per foot;

$V_{p} \quad$ is the total volume pumped (theoretically $Q t$ ), in gallons; and

$V_{b} \quad$ is the volume removed from wellbore storage, in gallons.

The intent is to provide a value that can be used to make better estimates of the yield of the aquifer. For example, adjusted specific capacity was computed for a simulation for a 6-in. diameter hypothetical well pumping at $5 \mathrm{gal} / \mathrm{min}$ from an idealized aquifer. The adjusted value of specific capacity (adjusted for wellbore storage continuously for each increment of time in figure 20A) is much less than the unadjusted value during early time. By removing wellbore storage, the adjusted specific-capacity value for early time is a good estimate of the specific capacity for later time; thus, when multiplied by available drawdown the adjusted specific capacity is a better representation of well yield than if the unadjusted specific capacity had been used.

Consider, for example, an estimate of well yield from the $2 \mathrm{gal} / \mathrm{min}$ test completed in March 2008 at well CA 462 (fig. 8) during which about half of the water withdrawn during pumping is derived from wellbore storage. Pumping for 1 hour resulted in a drawdown of $43 \mathrm{ft}$ and specific-capacity value of 0.047 (gal/min)/ft. Multiplying the specific capacity by the available drawdown of $132 \mathrm{ft}$ provides an estimated well yield of about $6 \mathrm{gal} / \mathrm{min}$. However, water-level recovery after pumping had ceased indicated that water was being contributed to the well at a steady rate of only about $1.3 \mathrm{gal} / \mathrm{min}$ - about five times less than the estimated well yield. The 60-minute specific-capacity value would need to be substantially adjusted to be used to estimate long-term well yield. The adjusted specific capacity for well CA 462 is shown in figure $20 \mathrm{~B}$. The adjusted value is about $0.02(\mathrm{gal} / \mathrm{min}) / \mathrm{ft}$ at 60 minutes, which, when multiplied by $132 \mathrm{ft}$ of available drawdown is $2.6 \mathrm{gal} / \mathrm{min}$ - still larger than the apparent well yield of $1.3 \mathrm{gal} / \mathrm{min}$, but a better estimate than was made with the unadjusted specific capacity.
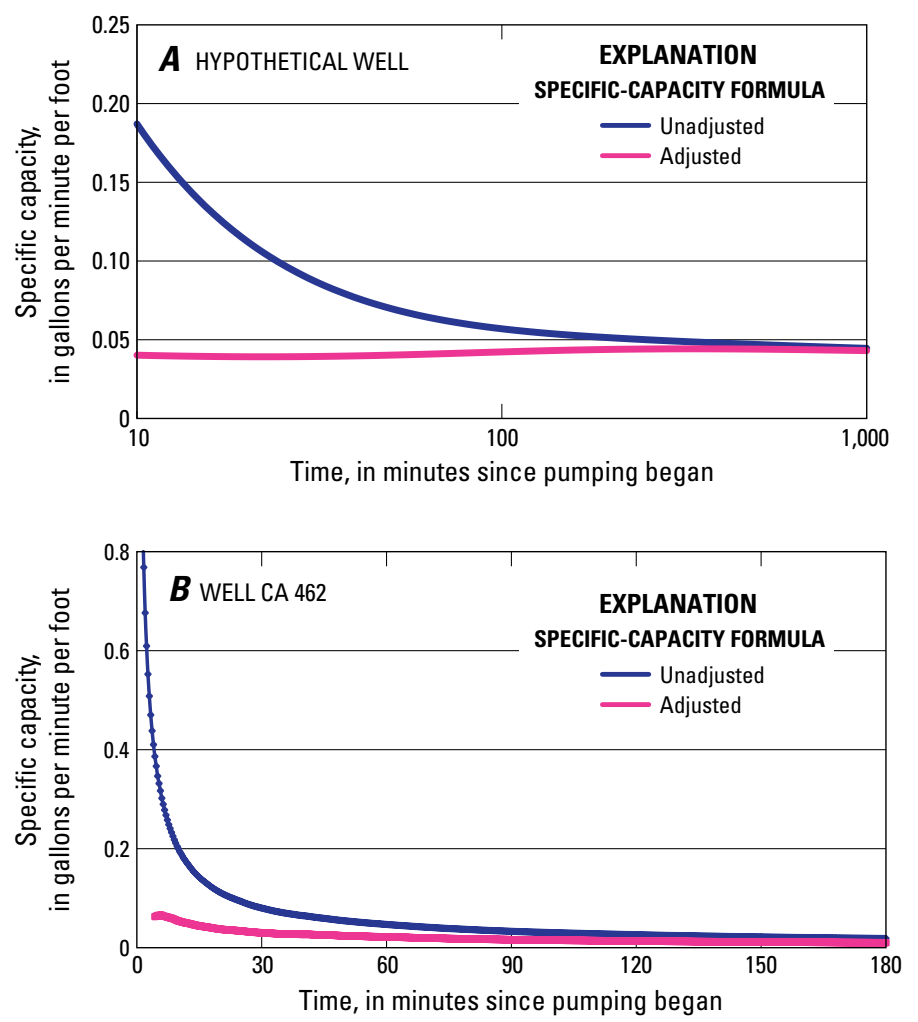

Figure 20. Specific capacity adjusted by removing water from wellbore storage compared to unadjusted specific capacity for $(A)$ the 6 -inch diameter hypothetical well (pumping rate $=5$ gallons per minute, $T=10$ feet squared per day, $S=0.0001$ ) and $(B)$ well CA 462 in Cambria County, Pennsylvania. 


\section{Specific-Capacity Tests Clearly Show Effects of Wellbore Storage}

One straightforward method of quantifying the effect of wellbore storage is to compute the volume of water provided by wellbore storage as a percentage of the pumped volume during small increments of time. The incremental percentage of water contributed by wellbore storage for an ideal aquifer should approach zero at late time. Deviations from the idealaquifer response can reveal information about the aquifer.

The drawdown data for specific-capacity tests at the six wells used in this study were usually reported every 20 seconds and, knowing the radius of each well, the incremental volume of water removed from the well between water-level measurements could be calculated. An example showing the change in the incremental percentage of volume from wellbore storage over time is shown for three tests completed at well CA 462 (fig. 21). The influence of wellbore storage was greatest in the early-time data of each test regardless of pumping rate; however, the influence of borehole storage stabilized at different levels for the different pumping rates.

The incremental percentage of water contributed from wellbore storage approached zero at a withdrawal rate of $1 \mathrm{gal} / \mathrm{min}$, as expected by theory; at $2 \mathrm{gal} / \mathrm{min}$ the percentage stabilized at about 37 percent; and at $4.5 \mathrm{gal} / \mathrm{min}$ the contribution was from 60 to 70 percent. The $2 \mathrm{gal} / \mathrm{min}$ test indicated that about $0.7 \mathrm{gal} / \mathrm{min}$ of water was steadily derived from the borehole and $1.3 \mathrm{gal} / \mathrm{min}$ was cascading into the well at a steady rate from the aquifer regardless of additional drawdown. Obviously, this well will not achieve an equilibrium condition. At a withdrawal rate of $4.5 \mathrm{gal} / \mathrm{min}$, about $2.9 \mathrm{gal} / \mathrm{min}$ was being removed from the borehole with $1.6 \mathrm{gal} / \mathrm{min}$ from the aquifer-again indicating a situation in which the pumping rate could not be sustained.

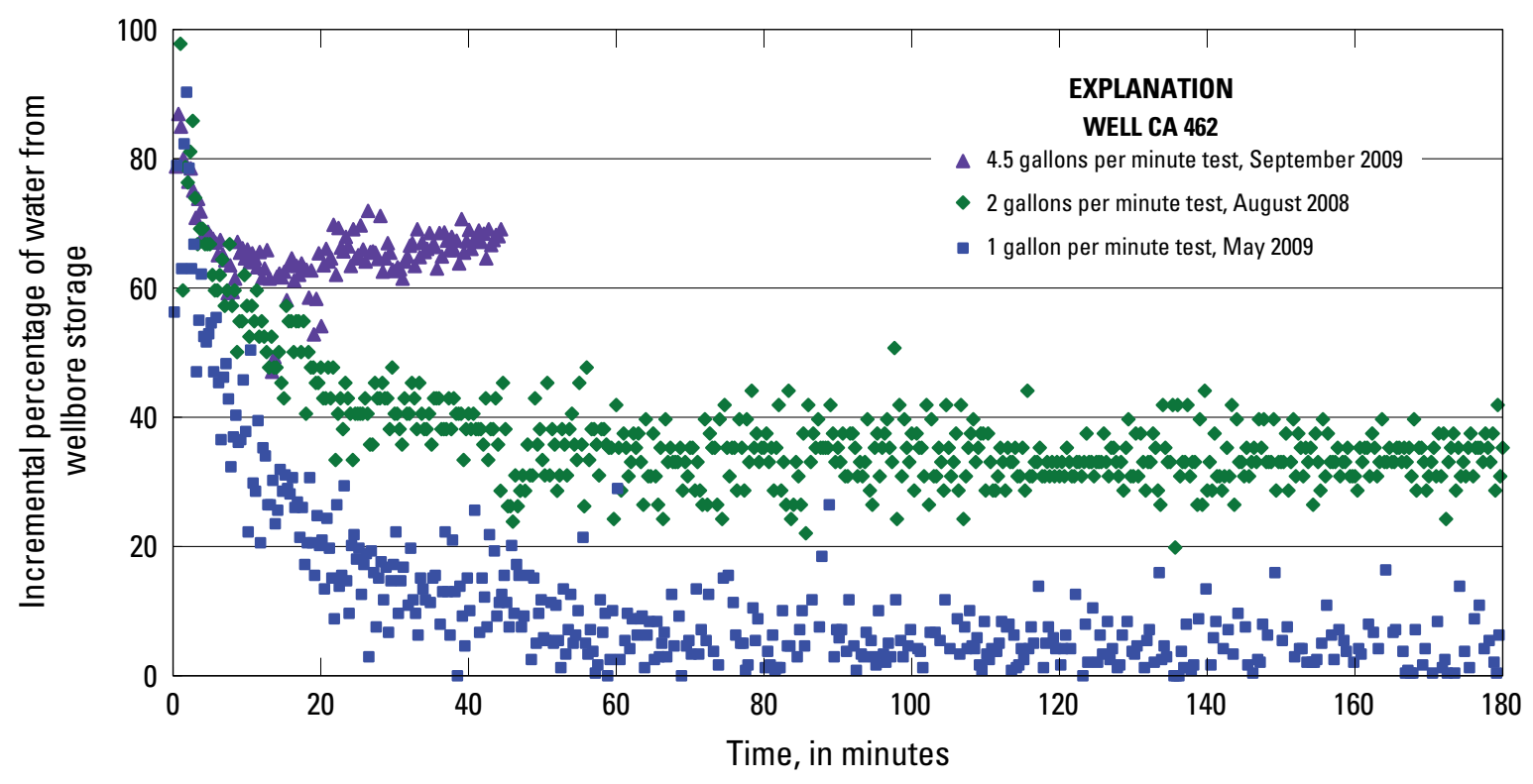

Figure 21. Incremental percentage of pumped volume provided by wellbore storage for three specific-capacity tests at rates of 1, 2, and 4.5 gallons per minute at well CA 462 in Cambria County, Pennsylvania. 


\section{Deviations in Borehole Diameter Can Make Test Results Difficult to Interpret}

If a substantial amount of water is contributed by wellbore storage, deviations in the well diameter with depth can be reflected in the water-level drawdown and recovery curves. Water-level data from the $1.5 \mathrm{gal} / \mathrm{min}$ specific-capacity tests in July and November 2008 at GR 541 clearly show these effects (fig. 22). The multiple straight-line segments of various slope could be interpreted as a lateral boundary, except that the changes in slope are at the same depth (not the same elapsed time) when multiple tests are examined. When the caliper log is compared to the water-level changes during the test, the slope of the water-level change is inversely related to well diameter (steepest slopes of water-level decline happen over intervals of smallest well diameter). The flat slope at a depth of about $46 \mathrm{ft}$ from 40-60 minutes of pumping is caused by a considerable volume of water stored in a void intersected by the well at that depth. Storage in the void is about 2-3 cubic feet $\left(\mathrm{ft}^{3}\right)$, based on the pumping rate of $1.5 \mathrm{gal} / \mathrm{min}$ and duration of the nearly straight-line drawdown segment for the tests completed in July and November 2008. Drawdown during the straight-line segment was about $0.2 \mathrm{ft}$, which could be interpreted as the approximate void height. Given that height, an effective void radius of $22-28$ in. would be needed to store $2-3 \mathrm{ft}^{3}$ of water. The caliper log showed an enlarged wellbore radius of about $10 \mathrm{in}$. at a depth of $46 \mathrm{ft}$ below land surface; but the volume of the wellbore alone cannot fully account for the volume of water provided from storage at that depth. Thus, this test shows that estimates of wellbore storage based on the casing diameter may be in error if the diameter of the uncased part of the hole differs from the diameter of the casing.

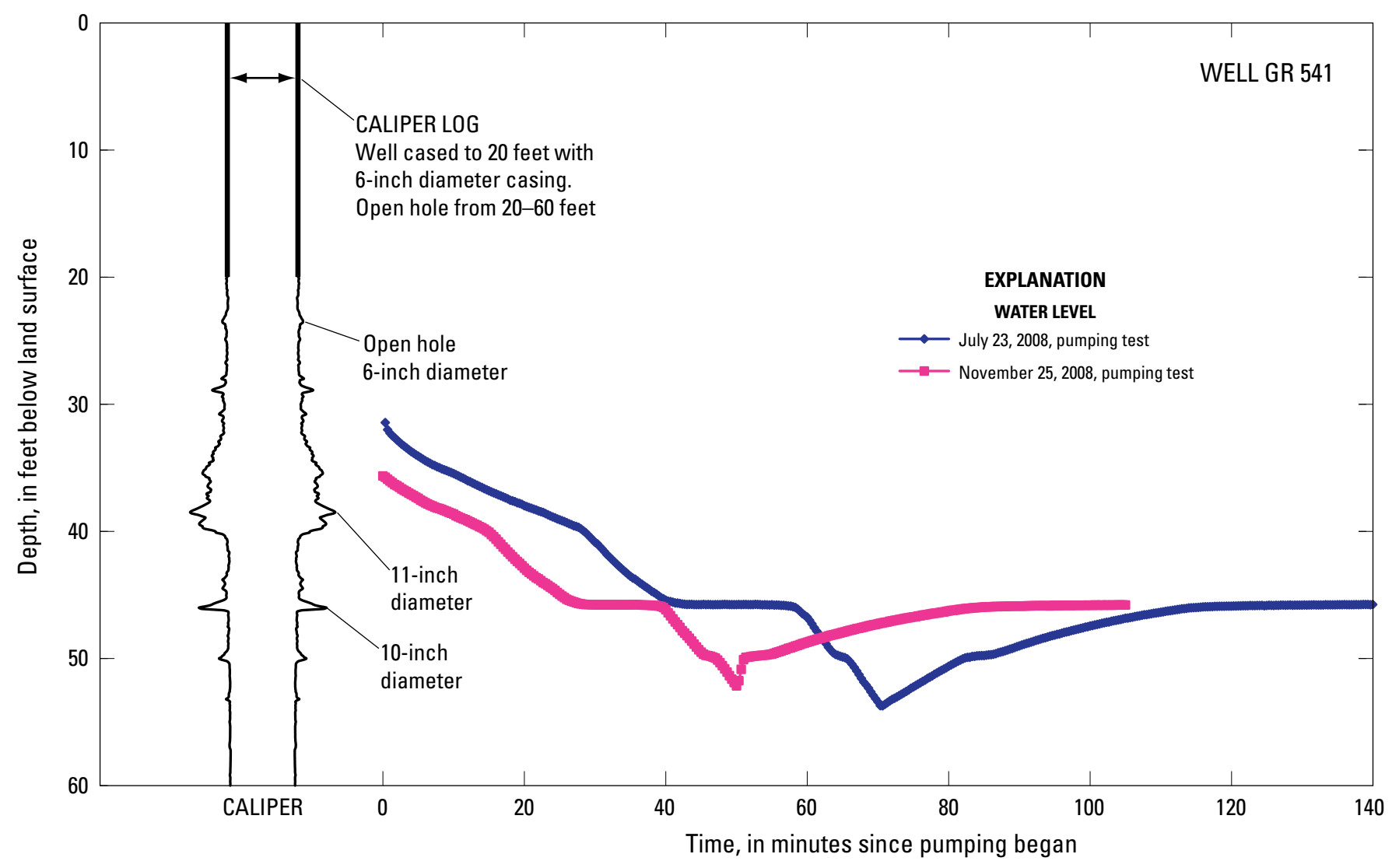

Figure 22. Caliper log and drawdown and recovery of water-level resulting from pumping at 1.5 gallons per minute on July 23 and November 25, 2008, showing effects of deviations in wellbore diameter in well GR 541 in Greene County, Pennsylvania. 


\section{Aquifer and Well Properties}

Specific capacity of a well may vary over time if the aquifer properties change or if the hydraulic properties of the well change. Aquifer properties can be changed by nearby mining activities (Callaghan and others, 1998, p. 2-24), but other possible natural causes can exist. The specific capacity of a well can decrease when the water table is low because the saturated thickness (and transmissivity) of the aquifer is smaller than when the water table is high. Often, the most productive water-bearing fractures are in the shallowest parts of the aquifer, so when water levels decline the decrease in transmissivity can be abrupt. The available drawdown in the well also decreases when water levels decline, which will decrease estimates of well yield based on available drawdown.

\section{Wet and Dry Periods Substantially Affected Specific Capacity at Well YO 1222}

Seasonal fluctuations in the water table can cause changes in the aquifer saturated thickness (and transmissivity). Seasonal water-level fluctuations were small and did not seem to affect well yield for five of the six wells tested in this study. The exception was well YO 1222, where a substantial change was observed.

Well YO 1222 had the greatest range of specific-capacity values among five tests completed for durations of $60 \mathrm{~min}$ utes or longer during 2007-09 (table 2 and fig. 18). Specific capacity ranged from 0.083 to 5.5 (gal $/ \mathrm{min}) / \mathrm{ft}$. Individual test results were near one of these extremes, with no test results at intermediate values. The different results can be explained by the depth to water in the well in relation to a major wateryielding zone intersected at $27 \mathrm{ft}$ below land surface (fig. 4), which may represent an intermittently perched water table. During periods when the water level was above this zone, the yield of the well was increased substantially compared to drier periods when the water level was below this zone. This water-yielding zone was not reported by the driller because the water level was below the zone at the time of drilling. The caliper log shows a small enlargement of the wellbore at this depth, but the deviation was slight and not suggestive of a major water-yielding fracture, though the fracture is visible on the borehole video (fig. 5). The effect of the water-yielding zone can be seen in the long-term hydrograph. The water-level recessions after periods of recharge showed a sharp increase in slope from $28-32 \mathrm{ft}$ below land surface, possibly indicating the dewatering of the perched water (fig. 23).

Dates of the specific-capacity tests are marked on the hydrograph of water-level fluctuations in YO 1222 (fig. 3). Tests on August 2007 and March 2008 were completed when the water-yielding zone $27 \mathrm{ft}$ below the surface was saturated; thus, drawdown was small and the computed specific capacity was large - about 5 (gal/day)/ft. Other tests were completed when the water level was below the water-yielding zone; therefore, the specific capacity was much less-about $0.1(\mathrm{gal} / \mathrm{min}) / \mathrm{ft}$. The water level in the well changes rapidly, so situations when the water-yielding zone is active can happen any time of the year; thus, the differences in well yield are not strictly a function of season.

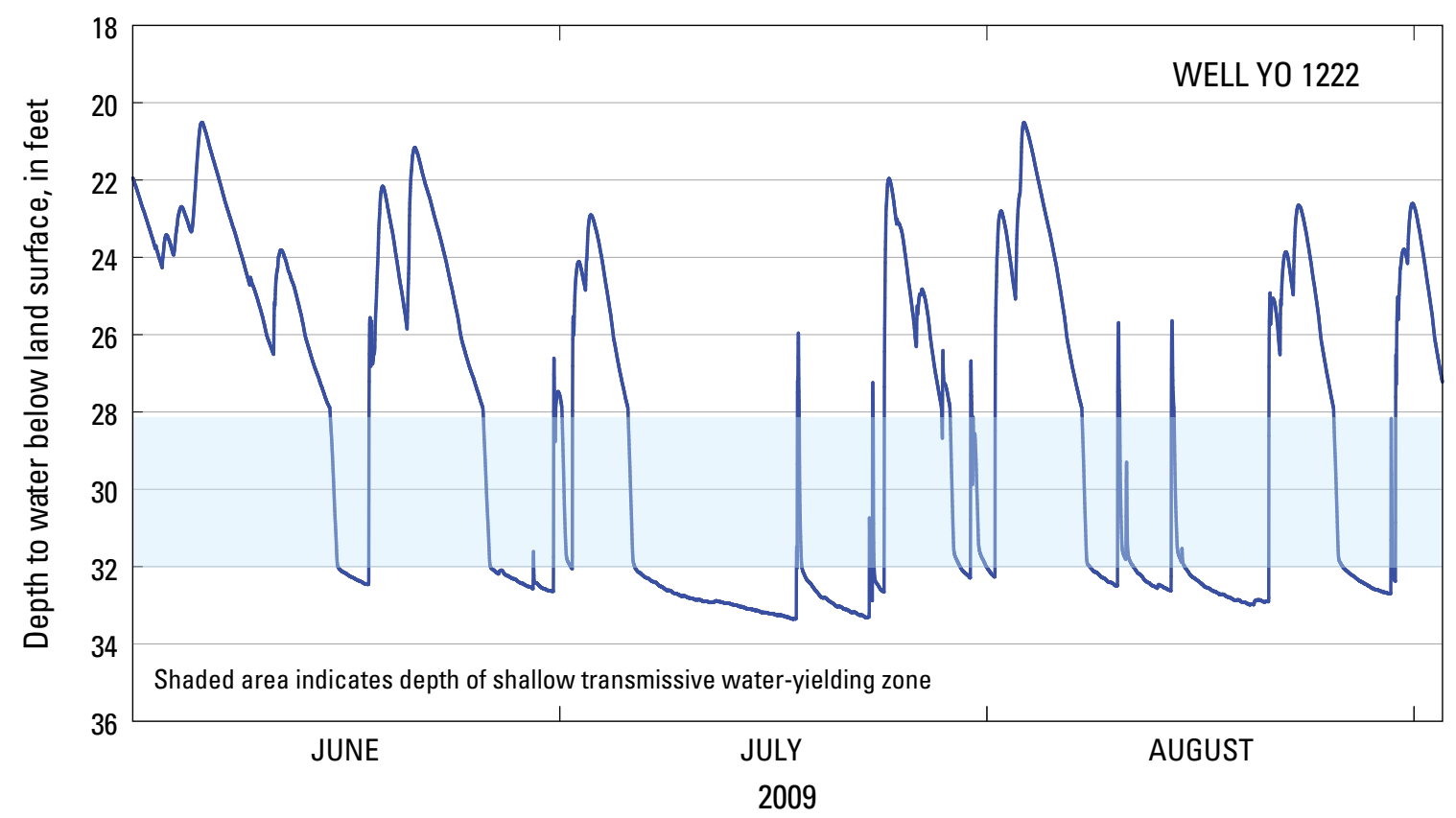

Figure 23. Water-level fluctuations in well YO 1222 in York County, Pennsylvania, during June to August 2009 showing change in recession slope at depth of a water-yielding zone 27 feet below land surface. 
Water-Yielding Zones Can Be Dewatered During Pumping

Changes in the water level in the well relative to major water-yielding zones can affect drawdown and specific capacity during a test. When the water level in the well is above a water-yielding zone, the water contributed from the zone is related to the difference in head between the aquifer and well. However, when the water level in the well drops below the zone, the effective water level at the zone, that is the boundary condition for flow from the zone, becomes fixed at a level corresponding to the depth of the zone. As the water level in the well drops farther, water cascades or seeps from the wateryielding zone at a rate independent of the water level in the well. A substantial change in transmissivity also can happen if the zone being dewatered is a major contributor to the well yield, and a change in slope on the drawdown-time curve will be noticeable. The effect of dewatering major water-yielding zones was clearly observed in the water-level drawdown data during tests at wells BV 156 at $57 \mathrm{ft}$ and WS 155 at $45 \mathrm{ft}$ (figs. 7A and 10A).

The importance of knowing the depth of the major wateryielding zones is exemplified by the specific-capacity tests at well WS 155 . Tests completed at pumping rates greater than $1 \mathrm{gal} / \mathrm{min}$ all show a break in slope of water-level drawdown and recovery at a depth of $45 \mathrm{ft}$ below land surface (fig. 10A). The specific capacity declines at the same rate for all tests at that well until water levels fall below $45 \mathrm{ft}$, at which time the rate of decline increases. Specific-capacity tests for WS 155 completed at different rates are comparable only if the water level in the well remains above the water-yielding zone at $45 \mathrm{ft}$ below land surface.

Deviations in the plots of water-level drawdown and recovery caused by dewatering of water-yielding zones can be distinguished from the effect of lateral boundaries away from the well. Deviations in plots would be seen at the same times for the different tests (regardless of pumping rate) if lateral boundaries were the cause of the change in slope, all other things being equal (Theis, 1940). Breaks in slope happened at the same water-level depth below land surface, not the same time after pumping began for the tests in this study, indicating a change in transmissivity with water-level drawdown.

\section{Change in Wellbore Skin May Change Well Yield}

Wellbore skin is a general term used to describe the hydraulic connection between the well and the aquifer immediately outside of the well. A positive wellbore skin refers to a zone of lessened transmissivity near the well and a negative wellbore skin refers to a zone of enhanced transmissivity. A positive wellbore skin could be created by plugging of fractures with precipitates of iron oxides in fractured-bedrock wells in coal areas.

Comparison of results from specific-capacity tests from this study to those results from earlier tests indicates that the yield of the unused wells may have decreased over the years. The test completed in 1999 in well AR 110 at $3.5 \mathrm{gal} / \mathrm{min}$ resulted in specific capacity values about three times greater than for tests completed during this study during 2008-09 (fig. 6B). The borehole video of AR 110 survey showed white flocculent floating in the well as the camera was lowered (fig. 24). Precipitates may have formed in small water-yielding fractures during the time between tests.

Specific-capacity values from historical tests at wells BV 156 and GR 541 were smaller than values computed during this study. These larger values today could be caused by an enhancement of the well yield by successive pumping. Fractures that were plugged during drilling or from precipitates could have been cleaned out during the pump tests during 2008-09. The specific capacity at well CA 462 was larger for the second of the two tests completed at $1 \mathrm{gal} / \mathrm{min}$ and at $2 \mathrm{gal} / \mathrm{min}$ (table 2 ).

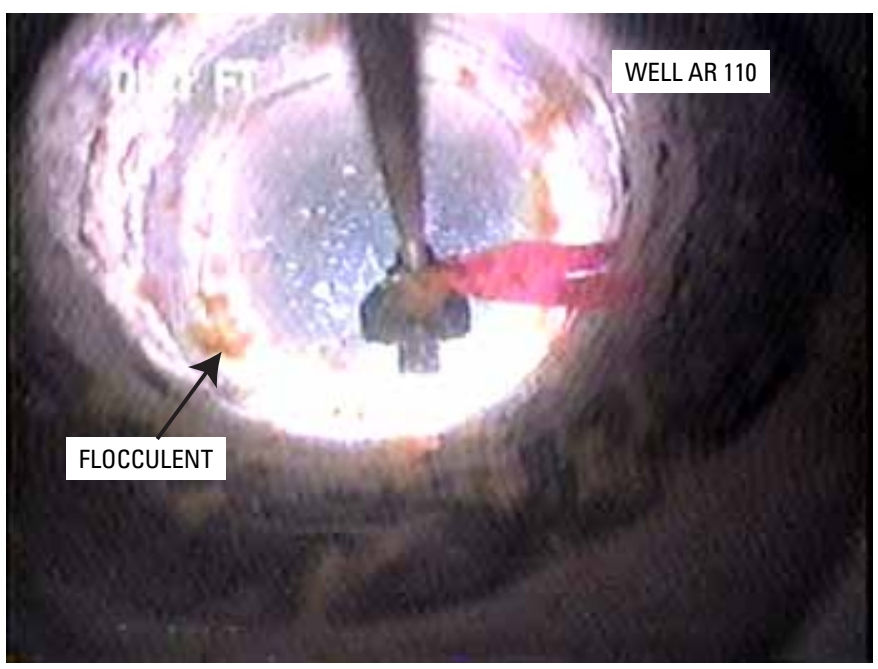

Figure 24. Image from borehole video log showing a particulate flocculent floating in the water in well AR 110. 


\section{Turbulent Flow}

\section{Step-Drawdown Tests Can Evaluate Effects of Turbulent Flow on Drawdown}

Step-drawdown tests are a standard method for evaluating the effects of turbulent flow and estimating well yield (Driscoll, 1986, p. 555). A step-drawdown test is completed by pumping the well in steps at successively greater pumping rates and monitoring the drawdown in the well. The duration of the steps is usually short-on the order of 60-90 minutes. Analysis of the drawdown for various pumping steps can be used to evaluate the magnitude of the turbulent-flow factor $C$. The effects of turbulent flow are influential because turbulent flow causes drawdown to increase at an exponential rate greater than would be expected if flow were strictly laminar (eq. 4).

\section{Turbulent Flow Was Not Significant During Step- Drawdown Test at YO 1222}

The step-drawdown test was used to analyze the effect of turbulent flow on drawdown in well YO 1222. Well YO 1222 was pumped for four 60-minute steps at rates of 2, 3, 4, and $5 \mathrm{gal} / \mathrm{min}$ in August 2008. The water-level drawdown and specific capacity during the test are shown in figure 11 . Examination of the change in specific capacity with time in figure 11B shows how the computed specific capacity reaches a value of about 0.11 at the end of each 60-minute pumping period, regardless of pumping rate. The specific-capacity value computed at the end of each pumping step would have been decreasing as pumping rate increased if turbulent flow would have been a major factor in this test.

The effect of turbulent flow can be quantified by plotting drawdown/pumping rate compared to pumping rate (Bierschenk, 1963, in Driscoll, 1986). The slope of the line is the turbulent-flow factor, $C$, and the intercept is the laminar-flow factor $B$ (eq. 4); thus, knowing $C$ and $B$, the drawdown for any pumping rate can be computed by using equation 4 . Plotting the data for the YO 1222 step-drawdown test gives a line with slope of $0.13 \mathrm{ft} /(\mathrm{gal} / \mathrm{min})^{2}$, and y-intercept of $8.49 \mathrm{ft} /(\mathrm{gal} / \mathrm{min})$ (fig. 25). However, the slope cannot be statistically shown to differ significantly from zero using the t-ratio (Helsel and Hirsch, 1992, p. 238) because the $p$ value of 0.32 was greater than the test criterion of 0.05 . Thus, the results indicate that turbulent losses are not influential at pumping rates from $1-5 \mathrm{gal} / \mathrm{min}$, and that the well has a maximum yield in excess of $5 \mathrm{gal} / \mathrm{min}$.

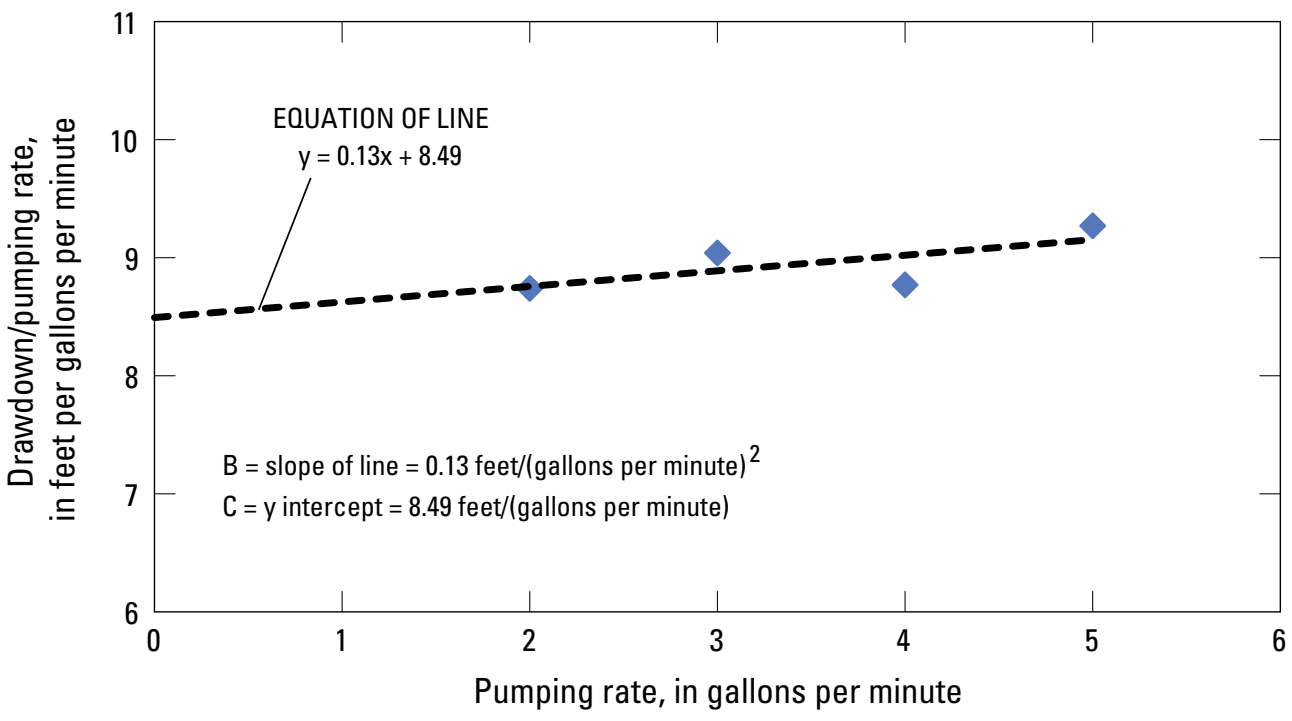

Figure 25. Determination of turbulent-flow factors $B$ and $C$ in equation 4 from the step-drawdown test at well YO 1222 in York County, Pennsylvania, in August 2008 by the method of Bierschenk (1963). 


\section{Application of Test Results}

Specific-capacity tests are used by PaDEP to document mining effects on domestic supply wells, to establish baseline well yield, and verify that replacement wells (if needed) have adequate yields. The six tests completed during this study, although not a large sample, provide some insights into the use of specific-capacity values for these purposes.

\section{Specific-Capacity Values Were Reproducible With Some Caveats}

Specific-capacity values generally were reproducible at the same well within about \pm 20 percent if the values were derived from tests completed at the same pumping rate and duration. The following caveats can apply regarding the application of specific-capacity values.

Accurate measurement of pump discharge is vital.Completing two tests at the same pumping rate requires accurate measurement of discharge for each test. The readings from two flowmeters can differ. Check flowmeter readings against a volumetric measurement.

Compare specific-capacity values for tests of the same

duration.--Specific capacity will decrease with time unless a test reaches equilibrium. Specific-capacity values computed after 180 minutes of pumping were 0 to 62 percent less than values after 60 minutes for tests that did not achieve equilibrium (table 3 ).

\section{Sometimes the pumping rate does not affect specific} capacity--Generally, tests completed at different pumping rates from about 1 to $6 \mathrm{gal} / \mathrm{min}$ resulted in similar specific capacities unless the large pumping rate caused the water level in the well to fall below a major water-producing zone. Unfortunately, the depths of water-producing zones usually are not known without information from driller's reports or geophysical logs, so a comparison of the results from tests completed at the same pumping rates would be prudent.

Wellbore skin can affect comparisons.-Water-yielding fractures in wells that are pumped infrequently may become clogged over time, thereby reducing the specific capacity of the well. Specific-capacity values from tests completed during 2008-09 at AR 110 may have been affected by plugging. Increases in specific yield at CA 462 for successive tests also are suggestive of the development of water-yielding fractures (unplugging) during the tests.

Depth of water relative to major water-producing zones is vital.- The most productive water-yielding zones tend to be shallow in stress-relief fractured bedrock, so natural water-level fluctuations in the aquifer possibly can cause large changes in aquifer transmissivity. This condition was documented at well YO 1222, where specific-capacity values varied by a factor of almost 50 during the study (table 5) because the water table fluctuated across a major water-yielding zone in the well.

\section{Documenting Baseline and Replacement Well Yield}

PaDEP determines if the supply of a well has been diminished by comparing the yield of a well tested after mining to the yield prior to mining. A replacement well, if needed, also is deemed adequate based on yield. Although well yield is simple to describe, difficulty arises in practice in determining and comparing yields from specific-capacity tests of differing rate and duration. Thus, the procedures for determining adequate well yield were outlined by PaDEP in the Technical Guidance Document for Water Supply Replacement and Compliance (Pennsylvania Department of Environmental Protection, 1999). That document defines well yield as the maximum pumping rate that can be sustained by a well without lowering the water level below the pump intake and recommends that well yield be determined from the specific capacity of the well measured during short-duration tests as:

$$
\text { WellYield }=S C(\text { adj }) \times A D
$$

where

$$
\begin{aligned}
& \text { Well Yield is in gallons per minute; } \\
& S C \text { (adj) is the adjusted specific capacity, in gallons per } \\
& \text { minute per foot; and } \\
& A D \text { is the available drawdown (distance from } \\
& \text { the static water level to a point about } 5 \mathrm{ft} \\
& \text { above the pump), in feet. }
\end{aligned}
$$

\section{Specific Capacity Values Can Overestimate Well Yields}

The approach for estimating well yield by multiplying the adjusted specific capacity times the available drawdown assumes that the rate of water contributed by the aquifer is directly related to drawdown in the well throughout the length of the well. Unfortunately, in low-yielding wells completed in fractured-bedrock aquifers, the most productive fractures commonly are detected in the shallow part of the well and deeper parts of the well serve only for water storage. Specific-capacity values computed from tests completed at low rates that do not cause much water-level drawdown are likely to overestimate the yield of the well because the effect of dewatering the shallow fractures has not been established.

For example, consider the two tests completed at about $1 \mathrm{gal} / \mathrm{min}$ for 180 minutes at well CA 462 . The specific-capacity values at the end of the 180 -minute tests were 0.10 and 0.14 (gal $/ \mathrm{min}$ ) $/ \mathrm{ft}$ (table 2 and fig. 8). Water derived from wellbore storage was small, about 8 percent of the total volume pumped, so the specific capacity adjusted to remove wellbore storage effects by the method of Pennsylvania Department of Environmental Protection (1999) results in adjusted values of about 0.09 to $0.13(\mathrm{gal} / \mathrm{min}) / \mathrm{ft}$. The estimated well yield, assuming $100 \mathrm{ft}$ of available drawdown, would be about 9 to $13 \mathrm{gal} / \mathrm{min}$. However, when the well was pumped at 
only $4.5 \mathrm{gal} / \mathrm{min}$, the water level drew down about $90 \mathrm{ft}$ in 45 minutes and pumping at $2 \mathrm{gal} / \mathrm{min}$ caused drawdown of about $100 \mathrm{ft}$ in 180 minutes. Clearly, the well could not sustain a pumping rate of $9-13 \mathrm{gal} / \mathrm{min}$ as indicated by the specificcapacity value multiplied by available drawdown.

A better approach is to complete a step-drawdown test or over pump at a constant rate great enough to cause the water level in the well to fall below the major shallow water-yielding zones, or if their depths are unknown, the well can be pumped nearly dry. The maximum well yield can be estimated from the rate of water-level recovery or by subtracting the percentage of incremental borehole storage at the end of the test from the pumping rate.

\section{Recovery Data Are Useful for Estimating Well Yield}

Recovery data for low-yielding wells were shown to be useful for estimating well yield. Much of the water discharged from the well is derived from wellbore storage during the pumping period; therefore, the contribution from the aquifer can be difficult to assess. However, for tests that show a straight-line plot of water-level drawdown and recovery when plotted on arithmetic axes, as seen during tests at wells AR 110, CA 462, GR 541, and WS 155, recovery data indicate the rate at which water is entering the well. The recovery, if the water level is pumped down to near the bottom of the well, should be the maximum rate that the well can produce. The rate could, however, slow down if the head in the water-yielding zone declines over time.

The inflow rate during the recovery period is computed as:

$$
I_{r}=7.48 \pi r^{2} \Delta w l_{r}
$$

where

$I_{r} \quad$ is the inflow during recovery, in gallons per minute;

$\mathrm{r} \quad$ is the well radius, in feet; and

$\Delta w l_{r} \quad$ is the water-level change rate during recovery, in feet per minute.

Figure 26. Drawdown and recovery of water level during the March 2008 specific-capacity test at well WS 155 in Washington County, Pennsylvania.
An example is given from the March 2008 specificcapacity test at well WS 155 (fig. 26). The well radius is $0.25 \mathrm{ft}$ and the linear change in water level during the first 4 minutes of rapid recovery after pumping ceased was $1.7 \mathrm{ft} / \mathrm{min}$. The inflow rate, determined from equation 8 , was about $2.4 \mathrm{gal} / \mathrm{min}$. This inflow rate is the rate at which water was cascading into the well from the major water-yielding zone at $45 \mathrm{ft}$ below land surface, and should be a good estimate of maximum well yield.

The yield estimate from recovery data can be compared to an estimate of inflow rate to the well during a straight-line drawdown period as:

$$
I_{\mathrm{p}}=Q-\left(7.48 \pi r^{2} \Delta w l_{p}\right)
$$

where

$$
\begin{gathered}
I_{p} \quad \begin{array}{c}
\text { is the inflow during pumping, in gallons per } \\
\text { minute; and }
\end{array} \\
\Delta w l_{p} \quad \begin{array}{c}
\text { is the water-level change rate during pumping, } \\
\text { in feet per minute. }
\end{array}
\end{gathered}
$$

For the period of water-level drawdown during the March 2008 test at well WS 155 , the pumping rate was $2.5 \mathrm{gal} / \mathrm{min}$, and drawdown rate from 140 to 180 minutes after pumping started was about $0.16 \mathrm{ft} / \mathrm{min}$. From equation 9 , the computed inflow during the pumping period would be about $2.3 \mathrm{gal} / \mathrm{min}$, which agrees closely to the rate of $2.4 \mathrm{gal} / \mathrm{min}$ computed from the recovery data.

Compare the estimate of well yield from the recovery data to an estimate derived by multiplying specific capacity (adjusted for wellbore storage) by available drawdown. Specific capacity at the end of the 180-minute test was about $0.13(\mathrm{gal} / \mathrm{min}) / \mathrm{ft}$ and available drawdown was about $95 \mathrm{ft}$ for well WS 155. Multiplied together, these numbers indicate a well yield of about $12 \mathrm{gal} / \mathrm{min}$, which is much larger than the actual maximum well yield.

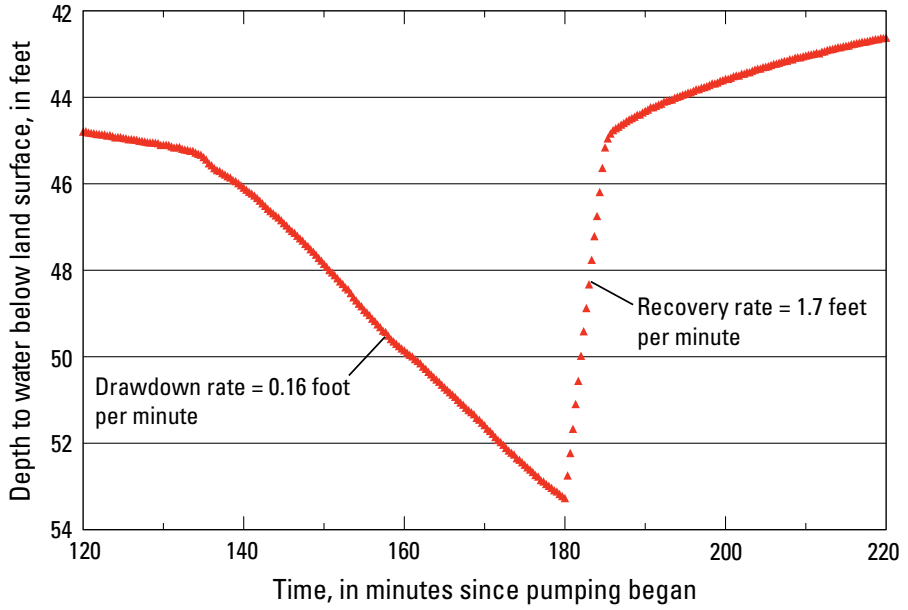




\section{Difficult to Use Analytical Models to Predict Well Yields From Test Results}

Mathematical models are powerful tools for estimating aquifer properties and making predictions about aquifer response to pumping. The models, under certain conditions, can predict drawdown in a well for any pumping rate, allowing the maximum yield of the well to be estimated. In practice, however, the use of analytical aquifer-test models to estimate well yields in low-yielding fractured-bedrock aquifers can be difficult, primarily because the aquifer properties and boundary conditions can change as drawdown increases. The use of automated aquifer-test software can get a good fit to the water-level data measured during a specific-capacity test, but if the model used to analyze the test does not incorporate the changing aquifer properties or boundary conditions predictions made for other pumping rates the model results will probably be erroneous. Specific-capacity tests at wells YO 1222 and WS 155 are two examples where changes in aquifer conditions caused the drawdown to be difficult to predict for different tests.

\section{Y0 1222}

A good fit of the data for the step-drawdown test at well YO 1222 completed in August 2008 was obtained by use of the analytical solution of Papadopulos and Cooper (1967) with transmissivity of $33 \mathrm{ft}^{2} / \mathrm{d}$, storage coefficient of $1.75 \times 10^{-7}$, and well diameter of 6.25 in. (fig. 27A). Turbulent-flow effects were not included in the model. The same model, if the aquifer was uniform and homogeneous, would accurately predict drawdown from the other aquifer tests with the use of the same aquifer properties determined from the step-drawdown test. However, this model does not accurately predict drawdown during the September 2009 test at $14 \mathrm{gal} / \mathrm{min}$ or the August 2007 test at $5 \mathrm{gal} / \mathrm{min}$ (fig. 27B and C).

The model prediction closely matches the measured drawdown for the September 2009 test at $14 \mathrm{gal} / \mathrm{min}$ until about $70 \mathrm{ft}$ of drawdown is achieved (fig. 27B). This result indicates that the transmissivity does not change substantially for pumping that causes less than $70 \mathrm{ft}$ of drawdown, which was true of the step-drawdown test. The observed drawdown becomes substantially greater than that predicted by the model for drawdown greater than $70 \mathrm{ft}$. The deviation is probably caused by a reduction in transmissivity of the aquifer caused by dewatering of fractures. The analytical model results show a large discrepancy between predicted and measured drawdown values for the August 2007 test at $5 \mathrm{gal} / \mathrm{min}$. The model predicted 40 times more drawdown than was measured during 180 minutes of pumping (fig. 27C). The water level was high during this test, causing a shallow, major water-yielding zone at $27 \mathrm{ft}$ below land surface to be saturated. The addition of this producing zone caused the transmissivity of the aquifer to be much greater in August 2007 than when the step-drawdown test was completed in August 2008.
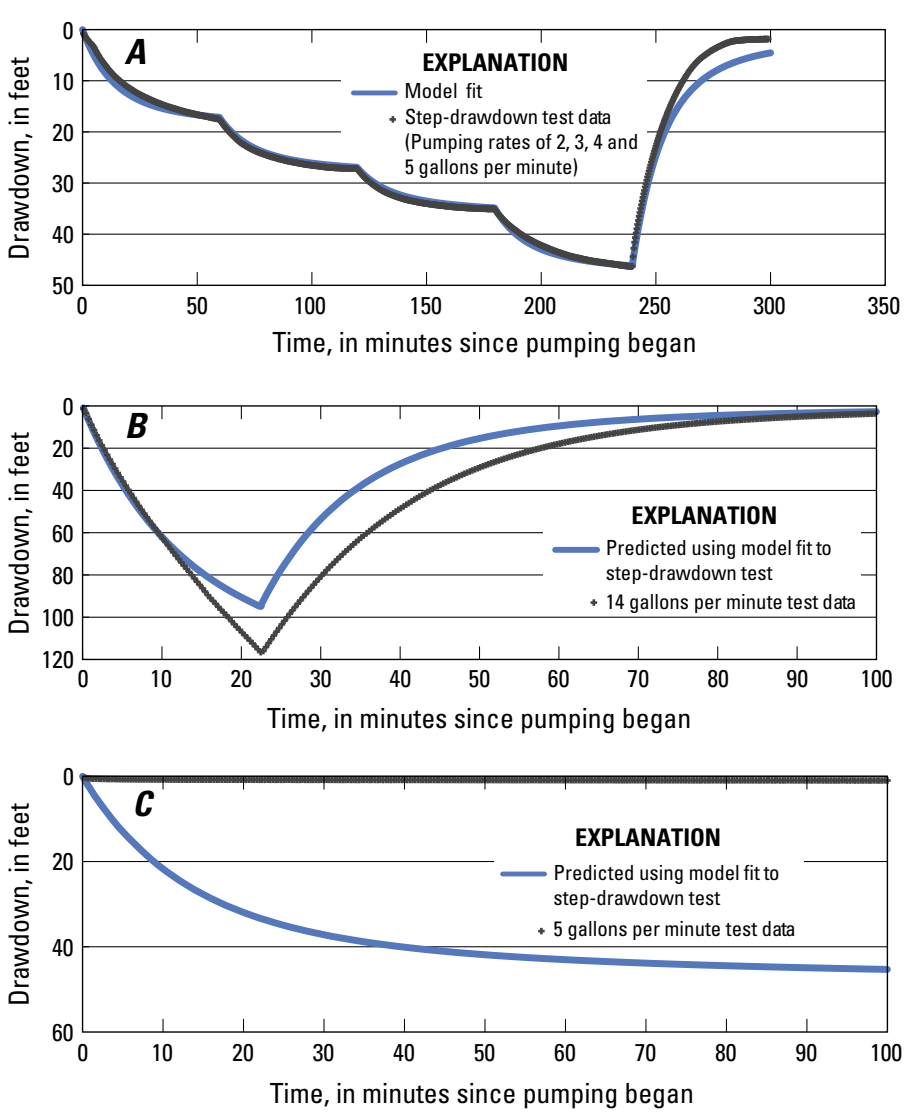

Figure 27. Measured drawdown from three tests at well YO 1222 in York County, Pennsylvania, and drawdown predicted with the analytical solution of Papadopulos and Cooper (1967) with transmissivity of 33 feet squared per day, storage coefficient of $1.75 \times 10^{-7}$, and well diameter of 6.25 inches. 


\section{WS 155}

Water-level drawdown and recovery from the May 2009 pumping at well WS 155 were simulated by use of the analytical solution of Barker (1988) with transmissivity of $64 \mathrm{ft}^{2} / \mathrm{d}$, storage coefficient of $8.7 \times 10^{-5}$, and well radius of $0.25 \mathrm{ft}$. The analytical solution simulates one-dimensional linear flow to the well as applied for this test, which, in reality, could be representative of flow in a vertical fracture intercepting the well. The well was tested by pumping at $1 \mathrm{gal} / \mathrm{min}$ for 60 minutes followed by a 40-minute recovery period, then pumped for 35 minutes at $6 \mathrm{gal} / \mathrm{min}$. When the water level in the well was above about $45 \mathrm{ft}$ below land surface, the analytical solution provides a good fit to the data (fig. 28). Thus, based on the $1 \mathrm{gal} / \mathrm{min}$ pumping and recovery period (first 100 minutes of the test), the analytical solution seems to be a good tool for predicting water-level change in response to pumping. At the higher pumping rate of $6 \mathrm{gal} / \mathrm{min}$, however, the predictive capability of the analytical solution breaks down when water level is drawn down below $45 \mathrm{ft}$ below land surface, at which point water begins cascading from that major water-yielding fracture. The estimated yield would be too large if the analytical solution was used to estimate a maximum well yield from the results of the $1 \mathrm{gal} / \mathrm{min}$ test.

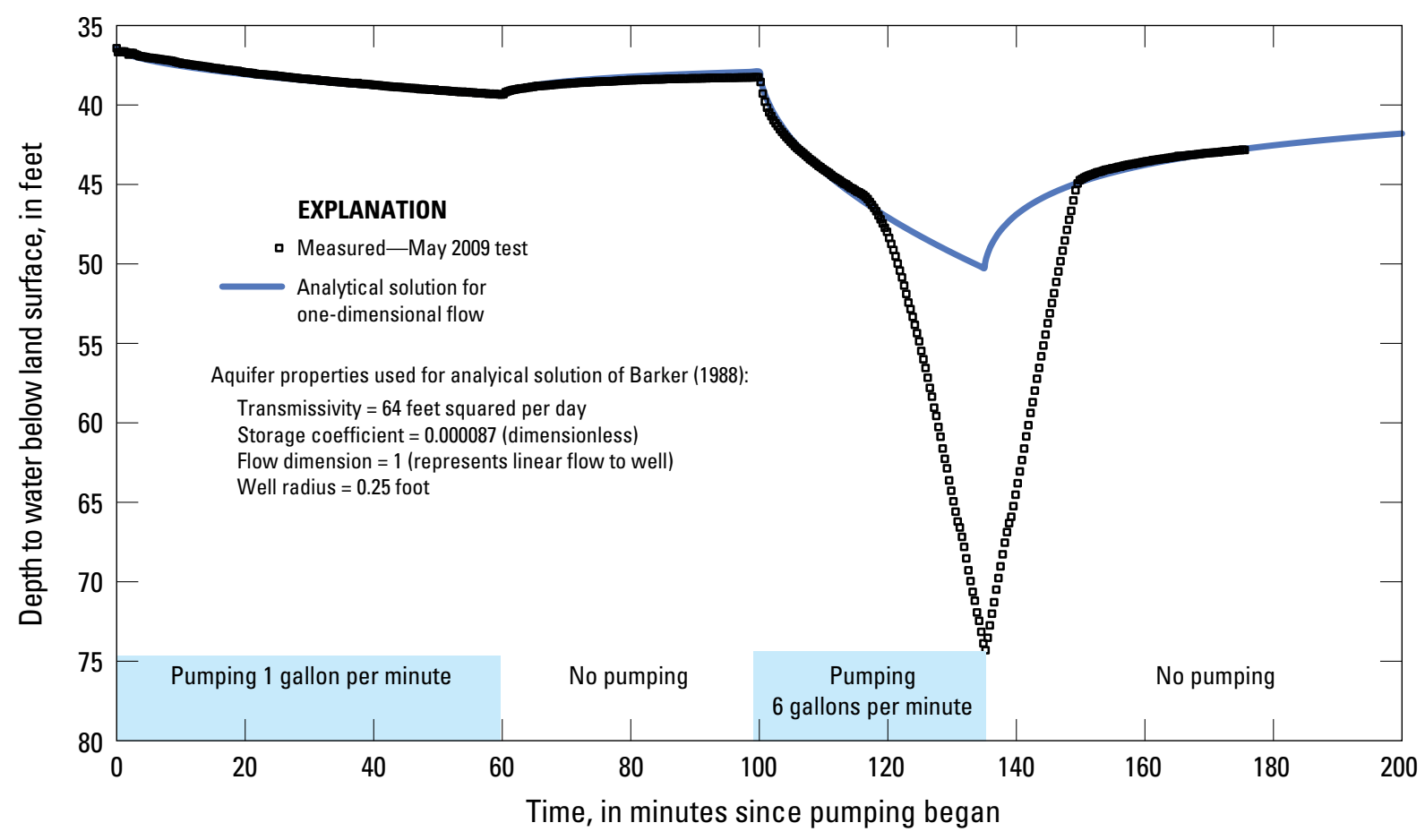

Figure 28. Measured water-level drawdown and recovery from the May 2009 specific-capacity test at well WS 155 in Washington County, Pennsylvania, compared to simulated water levels from the analytical solution of Barker (1988) for one-dimensional flow to the well. 


\section{Summary}

Pennsylvania Department of Environmental Protection (PaDEP) regulations require the mining company to restore or replace the water supply if a mining company diminishes the yield of a well to the point where the well is no longer adequate for the purposes served. PaDEP typically has used the specific-capacity test to determine mining effects on domesticsupply wells and to verify that replacement wells (if needed) have adequate yields. Factors other than mining can affect the results of specific-capacity tests, but the importance of those effects is not well understood, particularly with low-yielding wells in fractured-bedrock aquifers.

This report, by the U.S. Geological Survey, in cooperation with the PaDEP, Bureau of Mining and Reclamation, evaluates factors affecting the reproducibility and application of specific-capacity tests in six low-yielding water wells in Pennsylvania. The wells were completed in fractured-bedrock aquifers in mining areas - five in siliciclastic rocks of Pennsylvania and Permian age in the bituminous coal fields of western Pennsylvania, and one in limestone of Cambrian age in southcentral Pennsylvania that are quarried for several industrial uses. Factors affecting specific capacity such as pumping rate, duration of pumping, aquifer properties, wellbore storage, and turbulent-flow well losses were assessed by theoretical analysis and by completing multiple tests. Specific-capacity tests, lasting from 22 to 240 minutes, were completed 24 times at the 6 wells during 2007-09 and data were available from 5 tests completed on four of the wells prior to this study. In addition to pumping each well, video surveys were completed in each well and geophysical logging was done in five of six wells to determine the depth, casing length, and location of water-yielding zones; and seasonal water-level changes were measured by continuous monitoring at each well.

Specific-capacity values were reproducible at the same well within about \pm 20 percent if the values were derived from tests completed at the same pumping duration and rate. The tests showed that unless the water level in the well reaches equilibrium, specific capacity will decrease with time. Specific-capacity values computed after 180 minutes of pumping decreased as much as 62 percent compared to the value after 60 minutes. Tests completed at different pumping rates (from about 1 to $6 \mathrm{gal} / \mathrm{min}$ ) compared closely unless the larger pumping rate caused the water level in the well to fall below a major water-yielding zone. Turbulent flow during the tests did not seem to substantially affect specific capacity at the rates tested.

The depth to water in the well relative to the major wateryielding zones was a major control on the reproducibility of specific-capacity tests. The most productive water-yielding fractures tend to be shallow in stress-relief fractured bedrock, so natural water-level fluctuations or pumping can cause large changes in specific capacity when the water level is drawn below a major water-yielding zone. At well YO 1222, specificcapacity was about 50 times larger when the water level was above a major water-yielding zone 27 feet below land surface than when the water was below this level. During pumping tests at high rates in wells BV 156, CA 462, and WS 155, the water level dropped below major water-yielding zones, causing specific-capacity values to be smaller by as much as 63 percent compared to tests at the same wells completed at pumping rates that allowed the water level to remain above the major water-yielding zone.

Water-yielding fractures in wells that are not frequently pumped may become clogged over time, thereby reducing the specific capacity of the well. Thus, specific-capacity values from historical tests may not be valid for evaluating mining effects if specific capacity has been reduced by plugging. Whether the smaller specific-capacity values from this study compared to historical tests at AR 110 have been affected by plugging or mining is unclear. The opposite effect, increases in specific yield, as shown in successive tests at CA 462, indicate a development of water-yielding fractures (unplugging) by pumping.

Pre- and post-mining specific-capacity tests on low-yielding wells in fractured-bedrock aquifers will be most comparable if the tests have been completed at the same pumping rate and duration. Ideally, pumping is held steady and the rate is carefully monitored. Interpretation of the tests will be facilitated if the depths of the major water-yielding zones are known and the tests are completed when water levels are at similar depths with respect to those zones.

Estimates of well yield determined by multiplying specific capacity by the available drawdown are likely to be too large when computed from tests completed at low rates that do not cause much water-level drawdown. Therefore, the effects of dewatering the shallow water-yielding zones do not become incorporated in the yield estimate. A better approach for estimating yield is to complete a step-drawdown test or over-pump at a constant rate until the water in the wellbore is nearly evacuated. The maximum well yield can be estimated from the rate of water-level recovery on the straight-line plot of water-level recovery when plotted on arithmetic axes or by subtracting the percentage of incremental wellbore storage at the end of the test from the pumping rate.

\section{Acknowledgments}

This project was the outgrowth of many discussions with Keith Brady of the PaDEP Bureau of Mining and Reclamation about the interpretation of specific-capacity tests at lowyielding wells. The test pumping and other field work was greatly facilitated by the assistance of Brad Kuntz of USGS. Jack Felbinger and Jay Hawkins, Office of Surface Mining, provided the borehole video for well GR 541. Thanks to Kenneth King of W.D. Mohney and Associates for data and access to well AR-110. 


\section{References Cited}

Barker, J.A., 1988, A generalized radial flow model for hydraulic tests in fractured rock: Water Resources Research, v. 24, no. 10, p. 1,796-1,804.

Bierschenk, W.H., 1963, Determining well efficiency by multiple step-drawdown tests: International Association of Scientific Hydrology, Publication 64, p. 493-507.

Callaghan, Thomas, Fleeger, G.M., Barns, Scott, and Dalberto, Al, 1998, Groundwater flow on the Appalachian Plateau of Pennsylvania in Brady, K.B.C., Smith, M.W., and Schueck, J., eds., Coal mine drainage predication and pollution prevention in Pennsylvania: The Pennsylvania Department of Environmental Protection [variably paged].

Commonwealth of Pennsylvania, 1982, Pennsylvania Code, Title 25, Environmental resources, Chapter 87 surface mining of coal, subchapter E, surface coal mines-Minimum environmental protection performance standards, section 87.119 hydrologic balance-Water rights and replacement.

Commonwealth of Pennsylvania, 1990, Pennsylvania Code, Title 25, Environmental resources, Chapter 77 noncoal mining, subchapter I, environmental protection performance standards, section 77.533 water rights and replacement.

Commonwealth of Pennsylvania, 1998, Pennsylvania Code, Title 25, Chapter 88 Anthracite coal, section 88.107 hydrologic balance-Water rights and replacement.

Commonwealth of Pennsylvania, 2005, Pennsylvania Code, Title 25, Chapter 89 Underground mining of coal and coal preparation facilities, subchapter F, subsidence control and water supply replacement, section 89.145 a water supply replacement-Performance standards.

Cooper, H.H., and Jacob, C.E., 1946, A generalized graphical method for evaluating formation constants and summarizing well field history: American Geophysical Union Transactions, v. 27 , p. $526-534$.

Driscoll, F.G., 1986, Groundwater and wells (2nd ed.): St. Paul, Minn., Johnson Filtration Systems, Inc., 1,089 p.

Duffield, G.M., 2007, AQTESOLV for Windows version 4.5: HydroSOLVE, Inc., Reston, Va.

Freeman, L.A., Carpenter, M.C., Rosenberry, D.O., Rousseau, J.P., Unger, Randy, and McLean, J.S., 2004, Use of submersible pressure transducers in water-resources investigations: Techniques of Water-Resources Investigations, book 8, chap. A3, 52 p.
Helsel, D.R., and Hirsch, R.M., 1992, Statistical methods in water resources: Studies in Environmental Science 49, Elsevier, New York, 522 p.

Heath, R.C., 1983, Basic ground-water hydrology: U.S. Geological Survey Water-Supply Paper 2220, 84 p.

Jacob, C.E., 1947, Drawdown test to determine effective radius of artesian well: Transactions, American Society of Civil Engineers, v. 112, p. 1,047-1,070.

Keys, W.S., 1990, Borehole geophysics applies to groundwater investigations: Techniques of Water-Resources Investigations of the United States Geological Survey, book 2, chap. E2, 150 p.

Kruseman, G.P., and de Ridder, N.A., 1990, Analysis and evaluation of pumping test data (2nd ed.): Wageningen, The Netherlands, Publication 47, International Institute for Land Reclamation and Improvement, $377 \mathrm{p}$.

Lohman, S.W., and others, 1972, Definitions of selected ground-water terms-Revisions and conceptual refinements: U.S. Geological Survey Water-Supply Paper 1988, $21 \mathrm{p}$.

Papadopulos, I.S., and Cooper, H.H., 1967, Drawdown in a well of large diameter: Water Resources Research, v. 3, no. 1 , p. 241-244.

Pennsylvania Department of Environmental Protection, 1999, Water supply replacement and compliance: Pennsylvania Department of Environmental Protection, Bureau of Mining and Reclamation Technical Guidance Document 562-4000$101,43 \mathrm{p}$.

Reed, J.E., 1980, Type curves for selected problems of flow to wells in confined aquifers: Techniques of Water-Resources Investigations of the U.S. Geological Survey, book 3, chap. B3, $106 \mathrm{p}$.

Stoner, J.D., Williams, D.R., Buckwalter, T.F., Felbinger, J.K., and Pattison, K.L., 1987, Water resources and the effects of coal mining, Greene County, Pennsylvania: Pennsylvania Geological Survey, Water Resource Report 63, 166 p., 2 pls., scale 1:50,000.

Taylor, L.E., and Werkheiser, W.H., 1984, Groundwater resources of the Lower Susquehanna River Basin, Pennsylvania: Water Resource Report 57, Pennsylvania Geological Survey, Fourth Series, Harrisburg, Pa, 130 p., 1 pl.

Theis, C.V., 1940, The source of water derived from wells: Civil Engineering, v. 10, no. 5, p. 277-280. 
Prepared by the West Trenton Publishing Service Center.

For more information concerning this report, contact:

Director

U.S. Geological Survey

Pennsylvania Water Science Center

215 Limekiln Road

New Cumberland, PA 07070

dc_pa@usgs.gov

or visit our Web site at:

http://pa.water.usgs.gov 


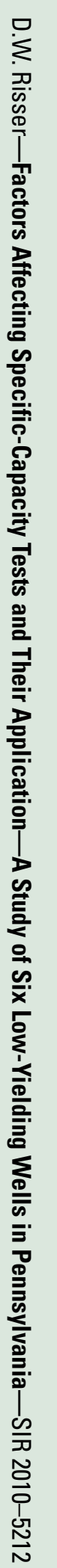

